KARINA MARTINEZ GAGLIARDO

EFEITOS DO EXERCíCIO FÍSICO NO ENVELHECIMENTO INICIAL DO PLEXO MIOENTÉRICO DO COLO DE RATO WISTAR: ESTUDO QUANTITATIVO, MORFOMÉTRICO E ULTRA-ESTRUTURAL. 
KARINA MARTINEZ GAGLIARDO

\section{EFEITOS DO EXERCíCIO FÍSICO NO ENVELHECIMENTO INICIAL DO PLEXO MIOENTÉRICO DO COLO DE RATO WISTAR: ESTUDO QUANTITATIVO, MORFOMÉTRICO E ULTRA-ESTRUTURAL.}

Tese apresentada ao Programa de Pósgraduação em Anatomia dos Animais Domésticos e Silvestres da Faculdade de Medicina Veterinária e Zootecnia da Universidade de São Paulo para a obtenção do título de Doutor em Ciências

Departamento:

Cirurgia

Área de concentração:

Anatomia dos Animais Domésticos e Silvestres

Orientador:

Prof. Dr. Romeu Rodrigues de Souza 
Autorizo a reprodução parcial ou total desta obra, para fins acadêmicos, desde que citada a fonte.

DADOS INTERNACIONAIS DE CATALOGAÇÃO-NA-PUBLICAÇÃO

(Biblioteca da Faculdade de Medicina Veterinária e Zootecnia da Universidade de São Paulo)

T.1648 Gagliardo, Karina Martinez

FMVZ Efeitos do exercício físico no envelhecimento inicial do plexo mioentérico do colo de rato Wistar: estudo quantitativo, morfométrico e ultra-estrutural/ Karina Martinez Gagliardo. -- São Paulo: K. M. Gagliardo, 2006.

$123 \mathrm{f}$. : il.

Tese (doutorado) - Universidade de São Paulo. Faculdade de Medicina Veterinária e Zootecnia. Departamento de Cirurgia, 2006.

Programa de Pós-graduação: Anatomia dos Animais Domésticos e Silvestres.

Área de concentração: Anatomia dos Animais Domésticos e Silvestres.

Orientador: Prof. Dr. Romeu Rodrigues de Souza.

1. Envelhecimento. 2. Atividade física. 3. Neurônios.

4. Intestino grosso. 5. Ratos. I. Título. 


\section{UNIVERSIDADE DE SÃO PAULO \\ Faculdade de Medicina Veterinária e Zootecnia \\ Cidade Universitária "Armando de Salles Oliveira" Comissão Bioética \\ CERTIFICADO}

Certificamos que o Projeto intitulado "Estudo quantitativo, morfométrico e ultraestrutural dos neurônios do plexo mioentérico de ratos. Qual o papel da idade e da influência do exercício físico nestes neurônios?", Protocolo n463/2004, utilizando 60 ratos, sob a responsabilidade do Prof. Dr. Romeu Rodrigues de Souza, está de acordo com os princípios éticos de experimentação animal da Comissão de Bioética da Faculdade de Medicina Veterinária e Zootecnia da Universidade de São Paulo e foi aprovado "ad referendun".

(We certify that the Research "Quantitative, morphometric and ultraestructural study of the myenteric neurons of the rats. What is the role of aging and of physical activity in those neurons?" protocol number 463/2004, utilizing 60 rats, under the responsibility of Prof. Dr. Romeu Rodrigues de Souza, agree with Ethical Principles in Animal Research adopted by Bioethic Commission of the Faculty of Veterinary Medicine and Zootechny of University of São Paulo and was approved "ad referendun", meeting.

São Paulo, 14 de maio de 2004

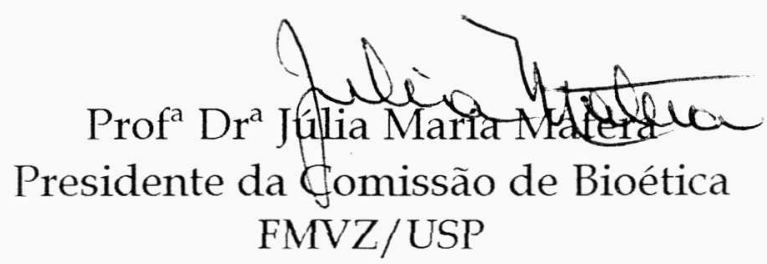




\section{FOLHA DE AVALIAÇÃO}

Nome: GAGLIARDO, Karina Martinez

Título: Efeitos do exercício físico no envelhecimento inicial do plexo mioentérico do colo de rato Wistar: estudo quantitativo, morfométrico e ultra-estrutural.

Tese apresentada ao Programa de Pósgraduação em Anatomia dos Animais Domésticos e Silvestres da Faculdade de Medicina Veterinária e Zootecnia da Universidade de São Paulo para a obtenção do título de Doutor em Ciências

Data:

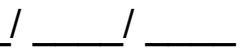

\section{Banca Examinadora}

Prof. Dr. Instituição:

Assinatura: Julgamento:

Prof. Dr. Instituição:

Assinatura: Julgamento:

Prof. Dr. Instituição:

Assinatura: Julgamento:

Prof. Dr. Instituição:

Assinatura: Julgamento:

Prof. Dr. Instituição:

Assinatura: Julgamento: 


\section{SENHOR}

Permita que eu aceite as minhas derrotas assim como fico feliz com as minhas

vitórias.

Que a cada dia eu possa agradecer pelo nascer do sol como pela noite que se vai.

Que eu possa perdoar a quem me fere sem mágoas, sem me sentir uma vítima por

isso.

Que eu entenda que as dificuldades da vida fazem parte do meu crescimento como ser humano.

Que eu possa ser um ombro amigo a quem precise, sem me sentir especial por isso.

Que eu seja humilde e perceba que a minha volta outros sofrem bem mais do que

eu.

Que eu consiga sorrir mais, chorar menos e ser feliz com o que me destes. Que eu consiga aprender que sou apenas mais um ser vivo nesse imenso universo só Seu, e respeite todas as outras formas de vida como sendo criação Sua. Que eu aprenda que a vida me foi dada de presente e não tenho o direito de tirála, pois a Ti ela pertence.

Que eu tenha mais bondade, piedade, carinho, compreensão e amor para com meu

irmão.

E principalmente, me ensine a não pensar em mim, deixando de ser egoísta até em minhas orações.

Amém 
Aos meus amados pais,

PEDRO ACÁCIO GAGLIARDO E SANDRA REGINA MARTINEZ GAGLIARDO, E ao meu marido,

FÁBIO LINARES SILVA,

Dedico este trabalho.

Sem a presença de vocês, tenho certeza que não teria conseguido.

$A$ vocês agradeço o melhor que tenho dentro de mim. Agradeço por vocês fazerem eu entender que mesmo em terreno árido é possivel existir flores.

Que devo sempre estender meus braços ao cultivo do Bem.

Eque não cai uma folha de árvore sem que o Pai permita.

Obrigada pelo apoio incondicional que vocês dedicam a mim.

Amo demais vocês! 
À Faculdade de Medicina Veterinária e Zootecnia da Universidade de São Paulo, por ser um dos pilares da minha formação.

À Fundação de Àmparo a Pesquisa do Estado de São Paulo - FAPESP, processo $n^{\circ}$. 04/04339-3, pelo apoio financeiro concedido para a realização desta pesquisa.

Ao meu orientador, Prof. Dr. Romeu Rodrigues de Souza, pela confiança, amizade e ensinamentos. Muito obrigada!

À Prof ${ }^{a}$ Dra. Sandra Stabille, pela incansável ajuda na elaboração desta tese. Muito obrigada por tudo!

À Profa Dra. Maria Angélica Miglino, pela oportunidade e apoio concedido na realização desta tese.

Ao Prof ${ }^{\circ}$ Dr. Francisco J. H. Blasquez, por toda ajuda e ensinamentos fornecidos para a elaboração desta tese. Muito obrigada!

Aos Profs. Pedro Primo Bombonato, José Roberto Kfoury, Paula Pappa e Irvênia Luiza S. Prada pela amizade, ensinamentos e companheirismo.

Ao técnico Diogo Palermo, por toda ajuda dada para a conquista desta tese. Sem você nosso experimento nem havia começado. Muito obrigada! 
Aos meus grandes amigos e técnicos, Edinaldo Ribas Farias ("Índio") e Ronaldo Agostinho da Silva, que acompanham meus passos desde a minha graduação.

Aos funcionários do Departamento de Cirurgia da FMVZ-USP, área de concentração Anatomia dos Animais Domésticos e Silvestres - Jaqueline Martins de Santana, Patrícia Aparecida Paixão e Maicon Barbosa da Silva, pela dedicação e companheirismo.

Aos funcionários da Comissão de Pós-graduação da Faculdade de Medicina Veterinária e Zootecnia da Universidade de São Paulo, pela colaboração nos trâmites legais para a realização do curso e defesa da dissertação.

Aos funcionários da Biblioteca da Faculdade de Medicina Veterinária $e$ Zootecnia pelo auxílio na correção desta dissertação.

Em especial a Naianne Kelly Clebis, minha GRANDE parceira de experimento e meu ente familiar mais novo (minha irmã muito mais velha). Nay, é difícil escrever em poucas linhas tudo que tenho a agradecer a você. Só você conhece os caminhos de pedras que tivemos que passar. Obrigada por nunca me deixar só e sempre confiar em mim. Você mora no meu coração.

Ao meu amigo Hildebrando Benedicto ("Hill") pela constante ajuda e amizade. Valeu!

Em especial as minhas GRANDES amigas Naianne Kelly Clebis (novamente), Priscila Teixeira de Barros Morais ("Prica"), Lílian de Jesus Oliveira, Janaina Munuera Monteiro ("Jana"), Renata de Britto Mari (Rê), Juliana Plácido Guimarães 
("Juca"), Patrícia Orlandini Gonçalez ("Patog") pela amizade, apoio, companheirismo, confiança e afeto. Vocês foram essenciais para que eu conseguisse chegar aonde cheguei. Sem o apoio de vocês, seria muito difícil minha caminhada. Obrigada por me levantarem quando mais precisei. Acreditarem em mim incondicionalmente. Estarem ao meu lado independente de circunstâncias. Para sempre guardarei vocês comigo. Adoro vocês!

Aos meus sinceros amigos Irena Fateeva, Maria da Glória dos Santos de Macedo, Danilo Busse Spironelli e Carlos Eduardo Bezerra de Moura agradeço todas as orações, a amizade e amor que dedicam a mim. Adoro vocês!

Aos amigos Emerson Ticonna Fioretto e Ana Rita de Lima agradeço os conselhos, as palavras de apoio e a amizade. Mesmo hoje distantes, guardo na memória os nossos melhores momentos. Obrigada pelo tempo feliz que me proporcionaram.

Ao meu irmão, Raphael Martinez Gagliardo, pelo constante apoio na elaboração desta tese. Sei que está distante, mas também sei que é passageiro. Amo você!

Aos meus tios, Ruy Martinez Galarça e Rose Araújo, pelo carinho e afeto.

A todos os pós-graduandos do curso de Anatomia dos Animais Domésticos e Silvestres pelo companheirismo. 


\section{RESUMO}

GAGLIARDO, K. M. Efeitos do exercício físico no envelhecimento inicial do plexo mioentérico do colo de rato Wistar: estudo quantitativo, morfométrico e ultraestrutural. [Effects of physical activity in the inicial aging of the myenteric plexus of colon of Wistar rat: quantitative, morphometric and ultraestructural study] 2006. 123f. Tese (Doutorado em Ciências) - Faculdade de Medicina Veterinária e Zootecnia, Universidade de São Paulo, São Paulo, 2006.

O conhecimento de todas as facetas que envolvem o processo de envelhecimento é uma necessidade atual, uma vez que a população idosa vem aumentando em todo mundo. O sistema digestório é um importante alvo das alterações do envelhecimento, sendo a constipação um freqüente distúrbio referido. Por esta razão, estudos sobre os neurônios do plexo mioentérico são necessários. Ainda, sabendo que a atividade física é uma terapêutica indicada para se evitar a constipação, este trabalho teve por objetivos estudar quantitativamente e qualitativamente os efeitos do envelhecimento nos neurônios NADH- e NADPH-diaforase reativos do plexo mioentérico do colo de ratos adultos (GRUPO A) e de meia-idade (GRUPO B), assim como o possível efeito da atividade física (corrida) sobre os neurônios dos animais de meia-idade (GRUPO C). Ainda, a presente pesquisa objetivou verificar as possíveis alterações da camada muscular (circular e longitudinal) do colo, assim como a ultra-estrutura neuronal nos diferentes grupos. Quanto à morfologia, nenhuma alteração neuronal ou no arranjo do plexo foi constatada. Entretanto, uma maior quantidade de colágeno ao redor do gânglio foi verificada nos animais do Grupo B. Alterações quantitativas foram encontradas tanto nos neurônios NADH-d reativos como nos NADPH-d reativos. Ambas populações neuronais tiveram a densidade diminuída com o envelhecimento, sendo significativa $(P>0,05)$ apenas nos neurônios NADPH-d reativos. Em relação à atividade física, somente os neurônios NADPH-d reativos tiveram a densidade significativamente 
diminuída $(P>0,05)$, enquanto que os neurônios $N A D H-d$ reativos tiveram a densidade ligeiramente aumentada. Nenhuma alteração significativa $(P>0,05)$ foi verificada na área do perfil neuronal e na espessura da camada muscular do colo.

Palavras-chave: Envelhecimento. Atividade física. Neurônios. Intestino Grosso. Ratos. 


\begin{abstract}
GAGLIARDO, K. M. Effects of physical activity in the inicial aging of the myenteric plexus of colon of Wistar rat: quantitative, morphometric and ultraestructural study. [Efeitos do exercício físico no envelhecimento inicial do plexo mioentérico do colo de rato Wistar: Estudo quantitativo, morfométrico e ultra-estrutural] 2006. 123f. Tese (Doutorado em Ciências) - Faculdade de Medicina Veterinária e Zootecnia, Universidade de São Paulo, São Paulo, 2006.

The known of all facets that involve this process is an actual necessity, once time the aging population is increasing in whole world. The digestory system is an important target of the aging alterations, being the constipation a frequent disturbance related. For this reason, studies about the neurons of the myenteric plexus are necessary. Moreover, knowing that the physical activity is a therapeutic recommended to avoid the constipation, this research have as objectives study quantitatively and qualitatively the effects of aging in the NADH- and NADPH-diaphorase reactive neurons of the myenteric plexus of the colon of adult rats (group A) and middle-aged (group B), as well as the possible effects of physical activity (running) about the neurons of middle-aged animals (group C). Furthermore, the present research also aimed verifies possible alterations in the muscle layers (circular and longitudinal) of colon, as well as the neuronal ultrastructure in all groups. In relation to the morphology, no neuronal alteration or in the arrangement of the plexus was showed. However, a major amount of collagen around the ganglion was verified in the animals of the group $B$. The quantitative alterations were showed both in the neurons NADH-d reactive and in the NADPH-reactive. Both neuronal populations had a decrease in the density with the aging, being significant $(P>0,05)$ only in the neurons NADPH-d reactive. In relation to the physical activity, only the neurons NADPH-reactive had a decrease significant in the density $(P>0,05)$, while the neurons
\end{abstract}


$\mathrm{NADH}-\mathrm{d}$ reactive had the density a little increased. No significant alterations $(P>0,05)$ were verified in the neuronal profile area and in the thickness of the muscle layers of the colon.

Key words: Aging. Physical activity. Neurons. Large intestine. Rats. 


\section{SUMÁRIO}

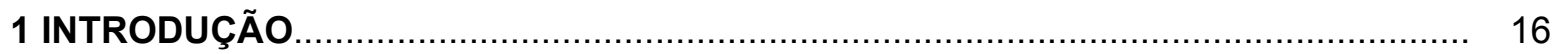

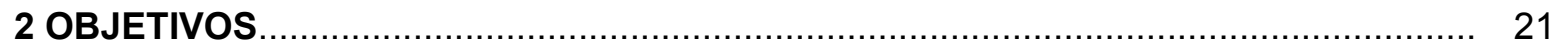

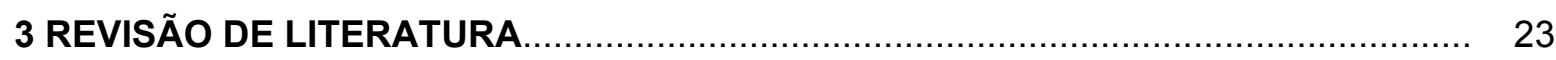

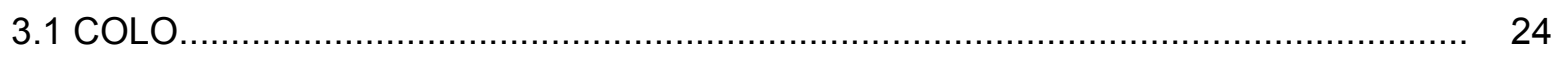

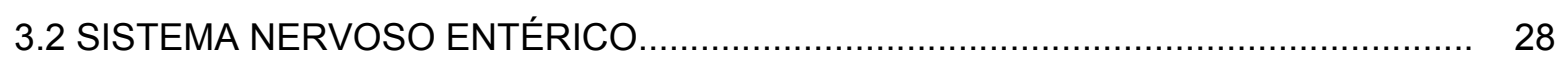

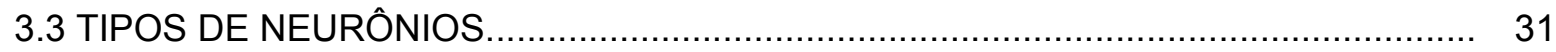

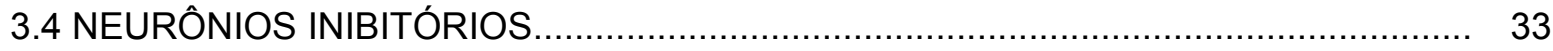

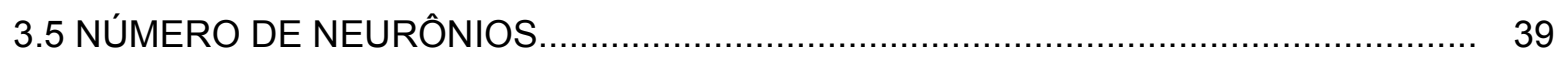

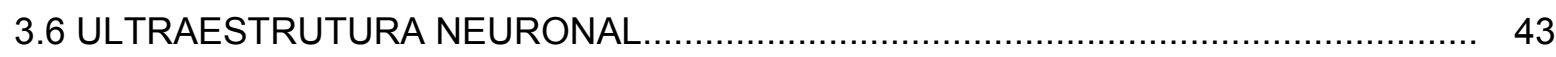

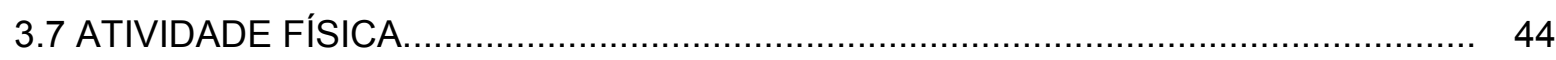

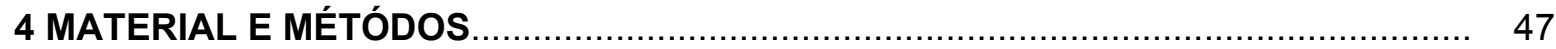

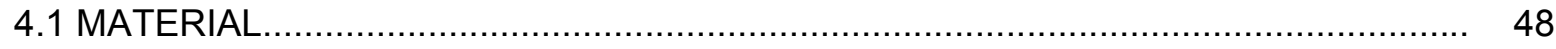

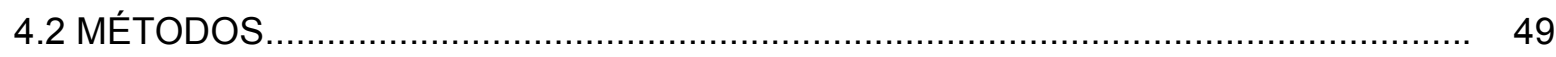

4.2.1 Protocolo Experimental de Atividade Física ................................................. 50

4.2.1.1 Protocolo de Atividade Física para os Animais do Grupo C................................. 51

4.2.1.2 Protocolo de Atividade Física para os Animais do Grupo B............................... 52

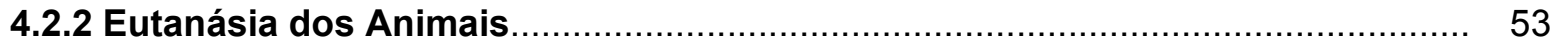

4.2.3 Processamento do Material para o Estudo Histológico................................... 53

4.2.3.1 Microscopia de Luz Convencional................................................................. 54

4.2.3.2 Microscopia de Luz de Cortes Semi-finos e Microscopia Eletrônica de

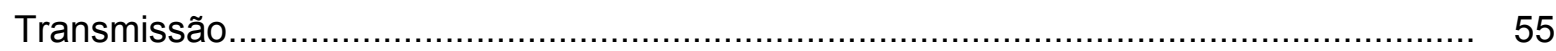

4.2.4 Processamento do Material para as Técnicas histoquímicas de NADH-

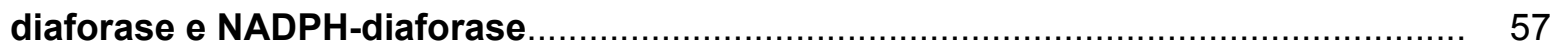

4.2.4.1 Técnica Histoquímica de NADH-diaforase ..................................................... 57

4.2.4.2 Técnica Histoquímica de NADPH-diaforase...................................................... 58

4.2.5 Obtenção dos Preparados de Membrana........................................................ 59

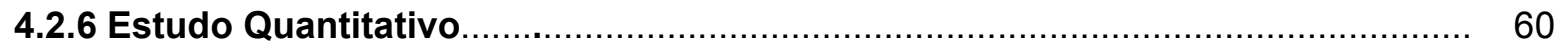

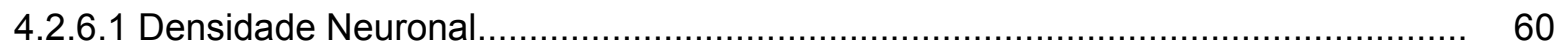

4.2.6.2 Estimativa do Número Total de Neurônios........................................................... 63

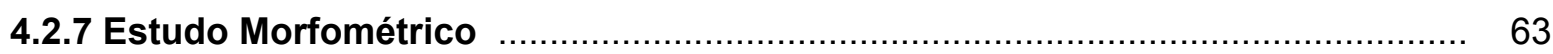

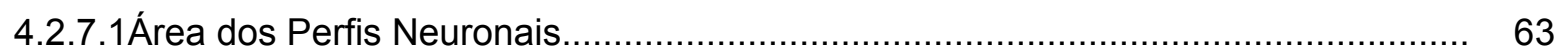

4.2.7.2 Espessura da Camada muscular................................................................... 64 


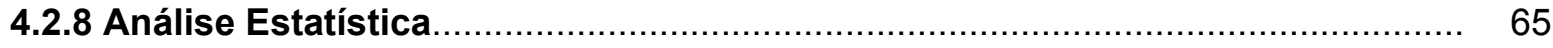

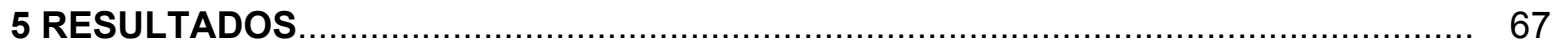

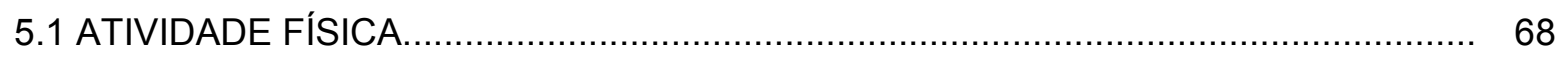

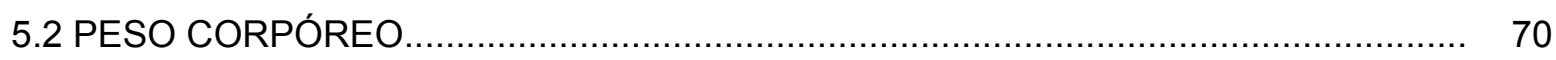

5.3 ANATOMIA MICROSCOPICA DO PLEXO MIOENTÉRICO ….................................. 73

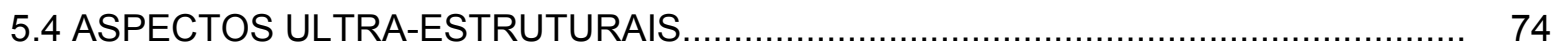

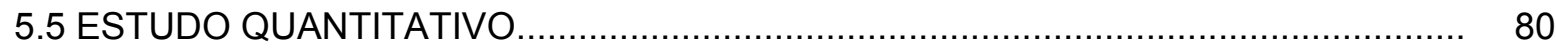

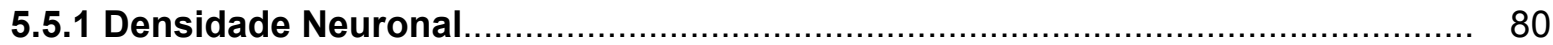

5.5.2 Estimativa do Número Total de Neurônios..................................................... 82

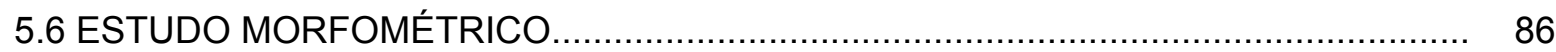

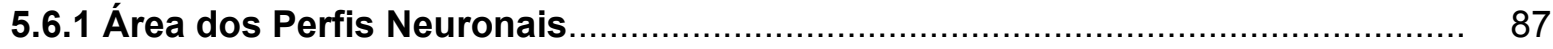

5.6.2 Espessura da Camada Muscular................................................................... 90

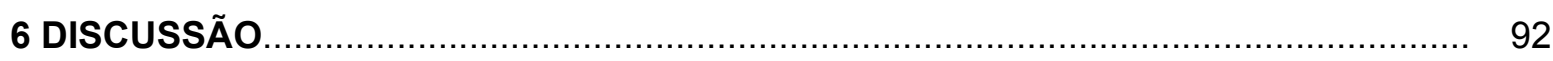

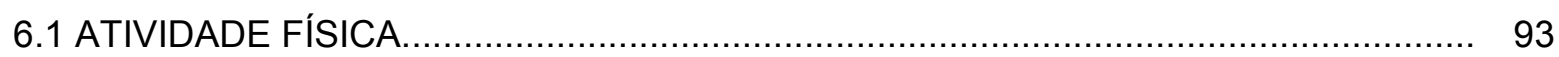

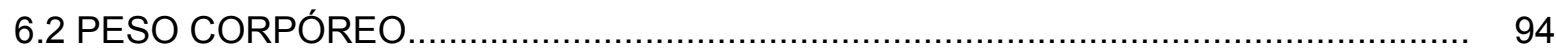

6.3 ANATOMIA MICROSCOPICA DO PLEXO MIOENTÉRICO .................................... 95

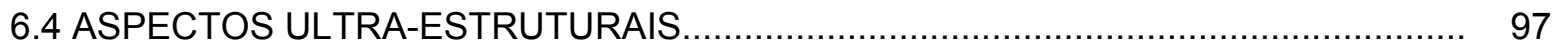

6.5 ESTUDO QUANTITATIVO E MORFOMÉTRICO .............................................. 98

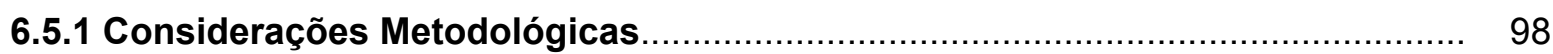

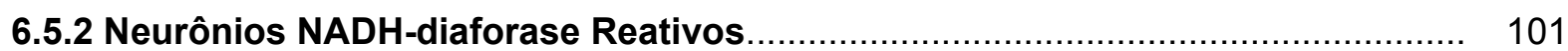

6.5.3 Neurônios NADPH-diaforase Reativos...................................................... 104

6.5.4 Hipóteses Referentes à Atividade Física......................................................... 106

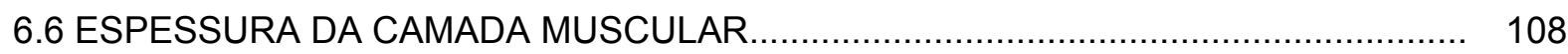

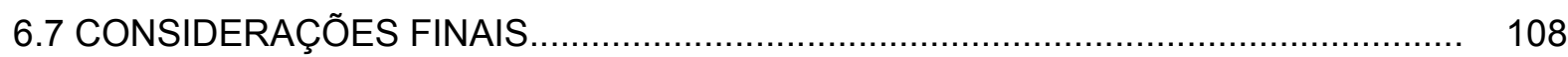

7 CONCLUSÃO

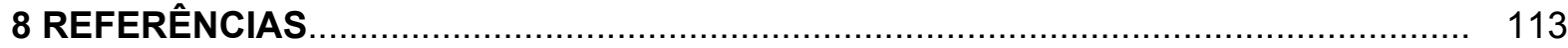


INTRODUCÃO 


\section{INTRODUÇÃO}

Nas últimas décadas aumentou o interesse por temas que envolvem a saúde do idoso. Em grande parte, isto se deve ao aumento da perspectiva de vida da população mundial. De acordo com a ONU (Organização das Nações Unidas), a expectativa de vida ao nascer aumentou de 46,5 anos (1950-1955) para 65 anos (1995-2000) e a cada ano ocorre um aumento de oito milhões de pessoas idosas. No Brasil, conforme os dados do último censo demográfico realizado em 2000, os idosos já representam 8,6\% da população total (IBGE, 2000). Por esta razão, conhecimentos mais precisos sobre o processo de envelhecimento é uma necessidade atual para auxiliar a minimizar os danos que ocorrem nesta etapa do desenvolvimento.

O envelhecimento é uma etapa natural do processo vital caracterizada pelo declínio geral na fisiologia dos diversos sistemas orgânicos (RUTTEN et al., 2003; SWEDA et al., 2003; WILEY, 2002). Em relação ao sistema digestório, sabe-se que a porção superior do trato gastrointestinal (TGI), particularmente a parte oral da faringe e o esôfago, e a parte inferior do trato, representada pelo colo e reto, freqüentemente apresentam distúrbios com o envelhecimento (HALL, 2002). As alterações comumente relacionadas em humanos e em modelos animais são: diminuição na motilidade esofágica (HOLLINS; CASTELL, 1974; KHAN et al., 1977; SOERGEL et al., 1964) e colônica (BUTT et al., 1993; MADSEN, 1992), retardo do esvaziamento gástrico (BROGNA et al., 1999; CLARKSTON et al., 1996; HOROWITZ et al., 1984; MOORE; TWEEDY; CHRISTIAN, 1983; SMITS; LEFEBVRE, 1996b) e o aumento no trânsito 
intestinal (ANURAS; LEONING-BAUCKE, 1984; BROCKLEHURST, 1985; MCDOUGLAS et al., 1984).

As alterações pontuadas com a senescência no TGI correlacionam-se, em parte, com a deterioração da função autonômica. É bem conhecido o fato que a regulação da motilidade é controlada principalmente pelos neurônios mioentéricos do sistema nervoso entérico (SNE) (inervação intrínseca), sendo estes, em sua maioria, neurônios inibitórios nitrérgicos e excitatórios colinérgicos (LOMAX; FURNESS, 2000; MITOLOCHIEPPA et al., 1998; PHILLIPS; KIEFFER; POWLEY, 2003). É facilmente compreensível que distúrbios destes neurônios (por exemplo, uma diminuição no seu número) podem estar relacionados com alterações na função do TGI.

Além do componente de inervação intrínseco, o TGI é modulado pelo componente extrínseco de inervação, cujas alterações podem proporcionar susceptibilidade maior à perda neuronal, uma vez que é relatada que tal inervação apresenta um efeito trófico na sobrevida dos neurônios mioentéricos (PHILLIPS; POWLEY, 2001).

As mudanças com o envelhecimento são variáveis nos diferentes modelos animais. Contudo, há o consenso que as mudanças são mais pronunciadas em extremo velho, com idade igual ou superior a 85 anos e 28 meses em humanos e ratos, respectivamente (HALL, 2002). Desta forma, se faz necessário o conhecimento de alternativas que possam prevenir tais alterações, auxiliando assim para um envelhecimento bem sucedido, menos vulnerável aos desafios do meio ambiente. Por 
isso, são imprescindíveis estudos utilizando modelos animais em fases que antecedem o envelhecimento propriamente dito.

A constipação é um sintoma usualmente reportado em pacientes senis e sedentários (DONALD et al., 1985; SARNA, 1991; WADE; COWEN, 2004), podendo resultar em complicações como obstrução intestinal por impactação fecal, megacolo idiopático e incontinência fecal (BROCKLEHURST,1985). A prática de atividade física de forma regular, associada a uma dieta rica em fibras, são preconizadas para estimular a atividade motora do colo e, conseqüentemente, facilitar a defecação. No entanto, os resultados de tal terapêutica são controversos. Alguns trabalhos descrevem que a atividade física não apresenta efeitos consistentes na função do intestino grosso (BINGHAM; CUMMINGS, 1989; ROBERTSON et al., 1993) e outros já relatam efeitos benéficos na instituição desta terapêutica (DAPOIGNY; SARNA, 1991; YOUNG, RICE; STEINHAUS, 1932).

Dada a capacidade plástica dos neurônios, possíveis efeitos benéficos podem ser observados com a instituição de um programa de atividade física, uma vez que já é relatada neurogênese em regiões do hipocampo em animais submetidos a tal atividade (ARIDA et al., 2004 a, b; BRAZEL; RAO, 2004; CHURCHILL et al., 2006; NEUPER et al., 1996). Desta forma, em busca de possíveis respostas de cunho morfológico sobre os efeitos benéficos da atividade física no TGI, este trabalho teve como metas esclarecer as possíveis mudanças neuronais (quantitativas e qualitativas) verificadas no colo de ratos de meia-idade (doze meses) após a instituição de um programa de atividade física. Ainda, a presente pesquisa também pretendeu descrever as possíveis alterações do desenvolvimento no plexo mioentérico, comparando ratos adultos (seis 
meses) com ratos de meia-idade (doze meses), como também as alterações na camada muscular (circular e longitudinal) entre os grupos de estudo.

A escolha do rato como material da pesquisa se deveu ao fato de este roedor apresentar sintomas similares aos observados em humanos durante o envelhecimento, sendo então considerados excelentes modelos para o estudo de tais alterações (SANTER; BAKER, 1993). Os resultados obtidos poderão auxiliar em terapêuticas que beneficiarão tanto a Medicina Humana quanto a Medicina Veterinária. 
OBJETIVOS 


\section{OBJETIVOS}

A presente pesquisa teve como finalidade estudar nos neurônios do plexo mioentérico do colo (porção ascendente e descendente) de ratos Wistar os efeitos do envelhecimento e da atividade física. Desta forma, os objetivos foram:

- Quantificar os neurônios reativos a NADH-diaforase e NADPH-diaforase;

- Mensurar a área seccional do perfil celular dos neurônios reativos a NADHdiaforase e NADPH-diaforase;

- Analisar a ultraestrutura neuronal;

- Analisar a espessura da camada muscular. 
REVISÃO DA LITERATURA 


\section{REVISÃO DE LITERATURA}

Neste capítulo será encontrado de forma didática uma revisão sobre o colo, o sistema nervoso entérico, os tipos de neurônios, os neurônios inibitórios, número de neurônios, ultra-estrutura neuronal e a atividade física.

\subsection{COLO}

Nos mamíferos, o intestino grosso contribui para o balanço hidroeletrolítico e absorção de nutrientes, controla a velocidade de formação e eliminação das fezes e é o habitat de milhões de microorganismos (CHRISTENSEN, 1989). O intestino grosso do rato é composto pelo ceco, colo ascendente (proximal), colo descendente (distal) e reto. Diferenças funcionais são descritas entre as duas porções do colo, isto é, o colo ascendente é considerado o primeiro sítio de estocagem do bolo fecal e o colo descendente serve para eliminar as fezes (HASLER; KUROSAWA; OWYANG, 1990; TAKAHASHI; OWYANG, 1998).

A estratigrafia do colo é caracterizada por ter uma mucosa com epitélio de revestimento do tipo colunar prismático com uma fina borda estriada (microvilos). A lâmina própria é rica em linfócitos e nódulos linfáticos, que freqüentemente atravessam a muscular da mucosa, invadindo a submucosa. Na submucosa são encontrados neurônios pertencentes ao plexo submucoso do sistema nervoso entérico (SNE). A 
camada muscular é bem desenvolvida e possui duas subcamadas de fibras, uma circular e outra longitudinal, entre as quais estão localizados os neurônios do plexo mioentérico do SNE. A serosa é constituída por tecido conjuntivo frouxo (JUNQUEIRA; CARNEIRO, 1995).

As diferenças funcionais entre as regiões do colo estão relacionadas ao peristaltismo. No colo proximal é encontrado um antiperistaltismo (ou retropropulsão), comprovado por meio de estudos radiográficos com contrastes, que possibilita reter o material fecal por um tempo maior, aumentando a capacidade de mistura, armazenagem e a absorção do excesso de fluidos. Já no colo distal é observada apenas uma intensa contração peristáltica (contração em massa) que resulta na propulsão das fezes já desidratadas (CHRISTENSEN et al., 1984; HASLER; KUROSAWA; OWYANG, 1990; MESSENGER; BORNSTEIN; FURNESS, 1994).

Como já é sabido, o peristaltismo é uma propriedade inerente de muitos tubos de músculo liso sincicial, onde a estimulação em qualquer ponto determina o aparecimento de um anel contrátil que, a seguir, se propaga ao longo do tubo. Contudo, o peristaltismo ocorre de maneira fraca, se é que ocorre, em qualquer porção do trato gastrointestinal (TGI) com a interrupção ou ausência congênita do plexo mioentérico ou mesmo com o bloqueio deste por fármacos como, por exemplo, a atropina. Desta forma, o peristaltismo efetivo requer um plexo mioentérico ativo (GALLIGAN; FURNESS; COSTA, 1989; GUYTON; HALL, 2002)

No colo são verificados três tipos de contrações: fásica rítmica, migratória gigante e a tônica. A primeira é desorganizada em relação a tempo e espaço, 
predominando em períodos de alimentação e jejum. Ela pode não se propagar ou se propagar apenas em distâncias curtas de poucos centímetros. Estas contrações são reguladas por ondas lentas e pelo complexo elétrico de contratilidade, causando a mistura e a lenta propulsão distal do conteúdo luminal. Já a migratória gigante é de grande amplitude, responsável pela oclusão luminal e por produzir o movimento de massa. Esta não é controlada por ondas lentas e sua propagação ocorre ininterruptamente por longas distâncias. Da mesma forma, a contração tônica também não é regulada por ondas lentas (LI et al., 2002).

Em humanos e cães a atividade motora predominante consiste em contração fásica rítmica. Infrequentes contrações migratórias gigantes ocorrem, na periodicidade de uma ou duas por dia. Ao contrário, no rato o predomínio é da contração migratória gigante. Contudo, diferente do humano, esta onda não se propaga por distâncias maiores que poucos centímetros. As diferenças no predomínio de tipos de contrações entre as espécies mencionadas decorrem dos diferentes tipos de armazenagem e da forma do conteúdo luminal. Humanos e cães formam armazenados uma ou duas vezes ao dia. Já os ratos armazenam e defecam freqüentemente. Assim, o colo do rato deve gerar ondas migratórias gigantes mais frequentemente (LI et al., 2002).

A regulação neural da contração migratória gigante se dá por impulsos excitatórios provenientes de neurônios colinérgicos, e impulsos inibitórios provenientes de neurônios nitrérgicos. A inibição da enzima precursora do óxido nítrico promove aumento na freqüência da onda migratória gigante no colo proximal, indicando que a liberação de óxido nítrico (NO) supri a freqüência desta. No entanto, nenhum efeito significativo é verificado na freqüência da onda migratória gigante no colo distal quando 
o NO é suprimido, indicando liberação insuficiente de NO nesta porção do colo para afetar a freqüência da contração migratória gigante espontânea. Ainda, a freqüência desta contração diminui distalmente (LI et al., 2002).

O peristaltismo envolve uma série de eventos coordenados que consistem na contração dos músculos longitudinais com simultâneo relaxamento do músculo circular aboral ao conteúdo alimentar e com intensa contração da musculatura circular e relaxamento da longitudinal oral ao conteúdo alimentar (HASLER; KUROSAWA; OWYANG, 1990). Mudanças neste funcionamento resultam em desconfortos abdominais como, por exemplo, dor, diarréia e constipação. Este último é um freqüente sintoma observado com o envelhecimento em humanos (BROCKLEHURST, 1985).

O processo de envelhecimento no TGI é marcado principalmente por aumento no tempo do trânsito colônico. Pessoas mais velhas, com idade entre 55 e 74 anos, apresentam um trânsito colônico mais lento do que pessoas jovens (21-27 anos) (MADSEN, 1992; WADE; COWEN, 2004). Em ratos, a redução no trânsito colônico também é verificada (aproximadamente 45\%) quando se comparam animais de cinco meses com os de 28 meses (MC DOUGLAS et al., 1984). A produção fecal (número de pelets fecais e massa fecal) (SMITS; LEFEBVRE, 1996a) e a variação na propulsão de pelets sólidos (WADE; EVANS; LIEB, 2002) também diminuem.

A constipação crônica de origem idiopática, isto é, uma desordem na motilidade colônica caracterizada por redução na freqüência, amplitude e duração da contração propulsiva do intestino grosso (MITOLO-CHIEPPA et al, 1998), pode resultar em disfunção de todo colo, devido à diminuição ou perda da contração migratória gigante 
controlada por mecanismos miogênicos, neurais e hormonais. Entre os mecanismos neurais, é relatado que nos pacientes com constipação idiopática crônica há diminuição na densidade neuronal, assim como alterações na produção de alguns neurotransmissores como, por exemplo, maior quantidade de NO e menor quantidade do peptídeo intestinal vasoativo (VIP) (CORTESINI et al., 1995; MITOLO-CHIEPPA et al., 1998).

\subsection{SISTEMA NERVOSO ENTÉRICO}

O SNE é o terceiro componente da divisão autonômica do sistema nervoso, sendo os outros dois o sistema nervoso simpático e o parassimpático. Este sistema é constituído por neurônios entéricos intrínsecos, feixes nervosos, células de suporte e fibras nervosas provenientes do sistema nervoso simpático e parassimpático (COSTA; FURNESS; LLEWELLYN-SMITH, 1987).

O SNE está presente por todo o comprimento do TGI. O arranjo deste sistema constitui os plexos entéricos que se encontram na parede do TGI. Dois grandes plexos ganglionados são encontrados: o plexo mioentérico (ou de Auerbach) localizado dentro da camada muscular externa, e o plexo submucoso situado na submucosa. O plexo submucoso é subdivido em três plexos separados: plexo submucoso interno (ou Meissner), situado sob a muscular da mucosa; o plexo submucoso externo (ou Schabadasch ou Henle), localizado diretamente adjacente à camada muscular circular; 
e um plexo intermediário, que está situado entre os dois anteriores. O plexo mioentérico regula a atividade muscular e o plexo submucoso está relacionado com funções da mucosa (GABELLA, 1979; SCHEMANN; NEUNLIST, 2004), embora não seja uma regra, pois há neurônios do plexo submucoso externo que inervam a camada circular e neurônios do plexo mioentérico que projetam para a mucosa (SCHEMANN; NEUNLIST, 2004).

Pequenos gânglios e fibras nervosas constituem os plexos ganglionados entéricos, formando uma malha embebida na parede do TGI, assim como também na vesícula biliar e no pâncreas. Os gânglios se interconectam formando um sistema nervoso com mecanismos de reflexos, integração e processamento semelhante aos do cérebro e da medula espinhal (FURNESS et al., 1992).

O plexo mioentérico pode ser dividido em plexo primário, secundário e terciário. O primário é formado por gânglios e fibras nervosas internodais que interconectam os gânglios transversalmente e longitudinalmente. O secundário é constituído por finas fibras nervosas orientadas em relação à musculatura circular e ligam os troncos primários entre si. O terciário é composto por ramos muito pequenos que se ramificam entre os espaços formados pelas mechas do plexo primário (SANTER; BAKER, 1993).

Nas diversas regiões do TGI, assim como nas diferentes espécies animais, são verificadas diferenças na quantidade e no formato dos gânglios. Desta forma, no estômago de ratos, por exemplo, os gânglios miontéricos são mais numerosos e maiores perto da curvatura menor, se tornando menos freqüente em áreas próximas a curvatura maior. No intestino delgado de ratos, este mesmo plexo forma cordões 
paralelos com a musculatura circular, sendo os gânglios mais dispersos. Já no intestino grosso de ratos, os gânglios são maiores e bem definidos (GABELLA, 1990, 1995), sendo encontrada maior densidade neuronal na região intermediária do que na antimesocólica (ARAÚJO et al., 2003).

Diferenças também são relacionadas às etapas do desenvolvimento. Em animais jovens e imaturos os gânglios são mais agrupados e relativamente maiores. Já em animais adultos, a maioria dos neurônios está situada dentro dos gânglios, mas alguns podem ser encontrados no trajeto dos feixes de fibras nervosas, os denominados conectivos (FURNESS; COSTA, 1987; GABELLA, 1979, 1987).

Os gânglios do plexo mioentérico de ratos da região do colo proximal (ascendente) apresentam um arranjo compacto desde embriões até a vida pós-natal, verificado por meio da imunomarcação utilizando PGP-9.5. Contudo, aos seis meses de vida pós-natal um aumento no tamanho dos gânglios e uma menor compactação são verificados (BELAI; COOPER; BURNSTOCK, 1995).

Em roedores (ratos, cobaias e coelhos), no colo descendente (distal) o plexo mioentérico tem um arranjo estrelado com gânglios grandes e uma superposição de fibras espessas, com troncos densamente corados, denominados "shunt fascicles". Apresentam uma distribuição regular por todo este segmento, não sendo encontrados plexos esparsos e irregulares (CHRISTENSEN et al., 1984).

A idade e condições patológicas podem afetar a morfologia neuronal. É descrito que o envelhecimento está vinculado a uma dilatação axonal em $100 \%$ dos neurônios que se dirigem à musculatura lisa circular tanto no intestino grosso como no intestino 
delgado. Também são verificados axônios dilatados dentro de gânglios individuais (PHILLIPS; KIEFFER; POWLEY, 2003; SANTER, 1994). Um aumento no perfil neuronal também está associado com o envelhecimento nos neurônios do colo e do reto. Tal aumento pode estar relacionado a uma hipertrofia compensatória em regiões onde há acentuada morte celular e maior dilatação axonal (PHILLIPS; KIEFFER; POWLEY, 2003).

\subsection{TIPOS DE NEURÔNIOS}

Diferentes tipos neuronais têm sido identificados por meio de métodos morfológicos, funcionais, farmacológicos e neuroquímicos (FURNESS, 2000; LOMAX; FURNESS, 2000).

Morfologicamente, os neurônios podem ser classificados como: Dogiel tipo I (neurônios motores com um axônio e muitos dendritos curtos), Dogiel tipo II (neurônios sensoriais com um único longo processo) e Dogiel tipo III (neurônios multipolares envolvendo outros neurônios) (BREHMER; SCHRÖDL; NEUHUBER, 1999; GABELLA, 1979). Atualmente, tem se classificado o neurônio de acordo com a morfologia do corpo celular e da projeção de suas fibras nervosas, de acordo com o código químico e da presumível função. Através desses critérios, Lomax e Furness (2000) já descreveram 17 diferentes tipos neuronais no colo distal da cobaia. 
No colo de camundongo, quatro tipos de neurônios foram identificados de acordo com suas projeções: (1) neurônios uniaxonais que inervam a camada muscular circular; (2) neurônios uniaxonais que inervam a camada muscular longitudinal; (3) neurônios uniaxonais cujos processos se direcionam para regiões oral (ascendente) e anal (descendente), sendo que alguns processos formam troncos nervosos dentro do plexo mioentérico; e (4) neurônios de superfície lisa com vários processos longos formando malhas dentro dos gânglios mioentéricos. Em cobaias, a morfologia equivalente destes neurônios tem sido identificada como: (1) neurônios motores do músculo circular; (2) neurônios motores do músculo longitudinal; (3) interneurônios; e (4) neurônios aferentes primários intrínsecos (FURNESS, 2000).

Dentre os 17 diferentes tipos neuronais encontrados no colo distal de cobaias, 13 são provenientes de neurônios encontrados no plexo mioentérico. Assim, os neurônios podem ser classificados como: neurônios intrínsecos primários aferentes (reagentes a $\mathrm{ACh} /$ calbidina/TK); interneuronios descendentes (reagentes a $\mathrm{ACh} / \mathrm{VIP}$ ), (reagentes a NOS), (reagentes a ACh/5-HT/CGRP/calbidina/tcalretina), (reagentes a $\mathrm{ACh} / \mathrm{VIP} / \mathrm{GRP} / \pm \mathrm{NOS} / \pm$ calbidina); interneuronios ascendente (reagentes a

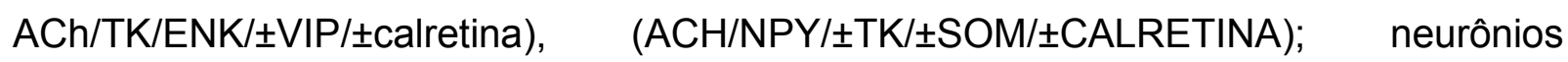
motores excitatórios para a musculatura circular (ACh/TK/土ENK); neurônios motores

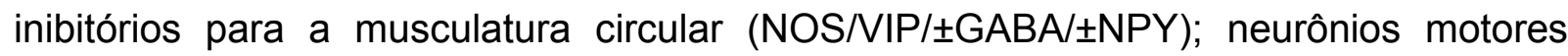
excitatórios para a musculatura longitudinal (ACh/TK/calretina); neurônios motores inibitórios para a musculatura longitudinal (NOS/ $\pm \mathrm{VIP} / \pm \mathrm{ENK}$ ); e neurônios intestinofugais $(\mathrm{ACH} / \pm \mathrm{NOS} / \pm \mathrm{VIP} / \pm \mathrm{GRP} / \pm$ calbidina/ \pm calretina) $(\mathrm{LOMAX} ; \mathrm{FURNESS}$, 2000). 
Quanto à fisiologia, os neurônios encontrados no SNE podem ser distinguidos por suas propriedades eletrofisiológicas. Os neurônios podem ser nomeados "S" ou "AH". A primeira nomeação refere-se a neurônios que apresentam rápido potencial excitatório pós-sináptico quando aplicado um estímulo elétrico em suas conexões interganglionares. Já a segunda nomeação refere-se a neurônios que apresentam um lento potencial excitatório pós-sináptico, seguido de uma hiperpolarização tardia que dura em média de um a 20 segundos. Os neurônios denominados "S" comumente são os interneuronios e os motoneuronios, e os neurônios classificados como "AH" os neurônios sensoriais (GALLIGAN et al., 2000; SCHEMANN; NEUNLIST, 2004).

Por meio de análises do código químico foi possível subdividir os diferentes tipos neuronais encontrados no SNE. Assim, foram encontradas diferenças entre o código químico dos neurônios motores excitatórios com projeções curtas e o dos neurônios motores excitatórios de projeções longas. Ainda, o código químico destes neurônios se diferencia de acordo com a região de inervação, isto é, se forem responsáveis por inervarem a camada muscular longitudinal ou a circular (FURNESS, 2000).

\subsection{NEURÔNIOS INIBITÓRIOS}

A inibição da função do TGI foi antigamente confinada apenas ao neurotransmissor norepinefrina liberado pelos nervos simpáticos. Contudo, hoje é sabido que no TGI são encontrados neurônios que não são classificados como 
adrenérgicos e nem como colinérgicos. Estes neurônios, comumente denominados de NANC (não adrenérgicos e não colinérgicos), são responsáveis pela mediação da maioria das respostas inibitórias no TGI e pela regulação de importantes reflexos, como o relaxamento descendente do colo, essencial para o reflexo peristáltico. 0 neurotransmissor primário destes neurônios é o NO, contudo outros transmissores como o peptídeo intestinal vasoativo (VIP) e o trifosfato de adenosina (ATP) também estão envolvidos (BOECKXSTAENS et al., 1993; FURNESS et al., 1992; FURNESS, 2000; GRIDER, 1993; SANDERS; WARD, 1992).

O VIP está quase sempre co-localizado nos mesmos neurônios que liberam NO (AIMI et al., 1993). Além do VIP, a co-localização de calretina com os neurônios que liberam NO também foi verificada em intestinos fetais de humanos (BELAl; BURNSTOCK, 1999).

O NO é conhecido como o maior mediador do relaxamento induzido por neurônios motores inibitórios NANC no TGI. Estes neurônios em regiões de esfíncteres são normalmente inativos, se tornando ativos somente com a passagem do bolo alimentar, quando então são responsáveis pela abertura do esfíncter. Desta forma a deficiência na produção de NO demonstrada em alguns distúrbios como, por exemplo, na estenose pilórica hipertrófica infantil, atalactasia e na doença de Hirschsprung, devem afetar a modulação do relaxamento esfinctérico. Ao contrário, os neurônios inibitórios motores NANC em regiões não esfinctéricas estão continuamente ativos, mantendo um estado persistente de inibição da atividade contrátil (CORTESINI et al., 1995). Assim, a liberação de NO facilita a propulsão do conteúdo colônico devido a mediação do relaxamento descendente (TAKAHASHI et al., 2000). 
O NO é formado a partir do aminoácido L-arginina. Através da enzima óxido nítrico sintase (NOS) e de um mecanismo NADPH e Ca 2+ ou calmodulina dependente são formados NO e L-citrolina. A produção de NO a partir da L-arginina é enzimática e duas formas de NOS têm sido identificadas. Uma é citosólica e cálcio e/ou calmudolina dependente. Esta enzima é constituinte (cNOS) e provavelmente sintetiza NO quando aumenta a concentração citoplasmática de cálcio. Esta enzima tem sido localizada no endotélio e nas células musculares (ecNOS) ou no SNE (ncNOS). A duração da atividade da NOS é curta, em torno de segundos a minutos (CHO, 2001; SANDERS; WARD, 1992).

A segunda forma de NOS é induzida (iNOS) por vários tipos celulares, incluindo macrófagos e células endoteliais. Uma vez que esta enzima é expressada, pode produzir NO por períodos prolongados, sendo este responsável por respostas patofisiológicas (CHO, 2001; SANDERS; WARD, 1992). Células musculares lisas também liberam a iNOS em resposta ao lipopolissacarídeo, um componente ativo de endotoxinas e outras citocinas (MONCADA; PALMER; HIGGS, 1991).

Os neurônios que sintetizam NO no TGI têm sido identificados por meio de técnicas histoquímicas baseadas na redução do sal tetrazólio solúvel para uma formação insolúvel azul escura na presença de NADPH-redutase (Scherer-Singer et al., 1983) e também por meio de técnicas imunohistoquimica para marcação de NOS. A distribuição da atividade NADPH-diaforase nos neurônios entéricos tem sido demonstrada ser idêntica a imunorreatividade ao NOS (BELAI; COOPER; BURNSTOCK, 1995; FURNESS et al., 1994). Contudo, a distribuição das fibras nervosas que coraram para NOS e NADPH-diaforase nos plexos secundários e 
terciários varia de uma região a outra. Por exemplo, no estômago, duodeno e íleo somente poucas fibras nervosas NOS-positivas foram coradas por NADPH-diaforase. Por outro lado, no ceco e colo distal quase todas as fibras nervosas NOS-positiva foram coradas por NADPH-diaforase (BELAl et al., 1992).

No SNE de cobaias, dois tipos de neurônios que expressam NOS são descritos. O primeiro tipo são os neurônios que se estendem por toda região do TGI e projetam ramos para a musculatura circular, sendo denominados neurônios motores inibitórios para a musculatura circular (FURNESS et al., 1994). A expressão de terminais nervosos NOS-positivos para a musculatura longitudinal é verificada apenas na tênia do ceco em cobaias (SANDERS; WARD, 1992). O segundo tipo são os neurônios que fornecem terminais para gânglios entéricos, particularmente gânglios mioentéricos do íleo e do colo, funcionando possivelmente como interneurônios. Os terminais de NOS são extremamente densos no colo proximal, embora estes sejam comuns no colo distal (FURNESS et al., 1994).

A maioria dos neurônios que expressa NO apresenta morfologia de célula Dogiel tipo I (neurônios motores com um axônio e muitos dendritos curtos) (FURNESS et al., 1994; KRAMMER; ZHANG; KUHNEL, 1994; SANDERS; WARD, 1992). No colo proximal de cobaias, os neurônios mais comuns que liberam NO foram classificados como células Dogiel tipo I, sendo uma proporção delas constituída por células grandes e irregulares, mas a maioria de tamanho pequeno a médio. O outro elemento celular mais encontrado foi a célula fusiforme com um único axônio e um ou mais dendritos lamelares irregulares, que foram, na maioria dos casos, somente vistos quando utilizado grande aumento microscópico. Os elementos celulares mais raros, aproximadamente 
$5 \%$ de neurônios NOS-imunorreativos do colo proximal, foram as células nervosas estreladas de tamanhos médio e grande com quatro a oito longos afilados processos (FURNESS et al., 1994).

Já no colo distal e no reto, os neurônios imunorreativos ao NOS no plexo mioentérico de cobaias foram todos classificadas como Dogiel tipo I, contudo, células fusiformes e estreladas, similares as do colo proximal, foram ocasionalmente observadas (FURNESS et al., 1994).

No colo, o NO contribui de maneira secundária com a capacidade absortiva, por relaxar a musculatura lisa intestinal (SANDERS; WARD, 1992) aumentando, assim, o tempo no trânsito da ingesta (MARTINEZ-CUESTA et al., 1997; MIZUTA et al., 1999) e permitindo mais tempo de contato para a absorção de fluidos e eletrólitos através do epitélio intestinal. O relaxamento, no colo de ratos, é abolido com a administração de LNAME (L-N G -nitro arginine methyl ester), que é um análogo da arginina, indicando que o relaxamento colônico é mediado primariamente pela liberação neuronal de NO (TAKAHASHI; OWYANG, 1998). Já no colo humano, ao menos dois transmissores inibitórios são necessários para exercer o relaxamento, o NO e o ATP (KEEF et al., 1993).

A sensibilidade das células musculares lisas ao NO é maior no colo proximal do que no colo distal de ratos. Contudo, nenhuma diferença na liberação neuronal de NO entre estas duas regiões foi observada. O número de neurônios que contem NOS é significativamente menor no colo distal quando comparado ao proximal. Ainda, Western blot análise também demonstrou redução na síntese de NOS no plexo mioentérico do 
colo distal. Esta diminuição é secundária a redução do gene da transcrição do NOS no plexo mioentérico devido ao menor número de células que contem NOS no colo distal ou a uma redução na transcrição do NOS por falta de estímulo (TAKAHASHI; OWYANG, 1998).

No colo de humanos, os neurônios motores inibitórios projetam preferencialmente em direção descendente (PORTER et al., 1997), sendo que apenas 0,3\% dos neurônios com projeções maiores que $10 \mathrm{~mm}$ em direção ascendente (oral) demonstram imunorreatividade a enzima NOS. Já os neurônios com projeções maiores que $10 \mathrm{~mm}$ em direção descendente (anal) apresentam imunorreativade em $46 \%$ ao NOS e $29 \%$ ao NOS conjugado ao Chat (PORTER et al., 2002).

No colo distal da cobaia, $39 \pm 2.5 \%(n=6)$ da população total de neurônios é imunorreativa ao NOS. Estas células apresentaram morfologia de células Dogiel tipo I (LOMAX; FURNESS, 2000). Nesta mesma região e espécie, Furness et al. (1994) reportaram $25 \%$.

Com o envelhecimento é relatada diminuição significativa na expressão de NOS nos neurônios do plexo mioentérico do íleo de ratos (JOHNSON et al., 1998) e no colo médio de ratos (TAKAHASHI et al., 2000). Uma diminuição também foi relatada nas fases iniciais do desenvolvimento (fetos, 1-2 dias de vida, 5-6 semanas) no intestino delgado (duodeno, jejuno e íleo) de porcos (VAN GINNEKEN et al., 2001). Contudo, Santer (1994) estudando o íleo e Phillips, Kieffer e Powley (2003) estudando o estômago, intestino delgado (duodeno, jejuno e íleo) e o intestino grosso (colo e reto) não relatam perda da subpopulação neuronal que expressa NO com o envelhecimento. 
Por outro lado, aumento na quantidade de neurônios que expressam NO com o envelhecimento foi verificado na vesícula biliar de cobaias quando comparado cobaias de 2-4 dias com cobaias de seis meses (aumento de $33,6 \%$ ) e posteriormente com cobaias de 12 meses (100\%) (SIOU; BELAI; BURNSTOCK, 1994). Da mesma forma, no colo proximal de ratos foi observado que $35 \%$ dos neurônios de embriões com 19 dias expressão NO, $76 \%$ dos neurônios nos animais com seis meses e que quase 100\% dos neurônios nos animais de 26 meses expressão NO (BELAl; COOPER; BURNSTOCK, 1995). Também foi reportado o aumento na quantidade de neurônios no íleo terminal de humanos (idade média de 80 anos) (BELAI; BURNSTOCK, 1999).

A não perda de neurônios nitrérgicos é consistente com a função protetora do NO, sendo que Cowen et al. (2000) sugerem que os neurônios que utilizam cNOS devem ter um aumento no mecanismo de defesa contra os radicais livres.

Na doença de Crohn (BELAI; BURNSTOCK, 1999) e na constipação crônica de origem idiopática, também se observa aumento no número de neurônios que expressam NO (CORTESINI et al., 1995).

\subsection{NÚMERO DE NEURÔNIOS}

A contagem do número de neurônios no plexo mioentérico tem sido realizada em várias espécies de mamíferos e referem-se ao número de neurônios por centímetro quadrado $\left(\mathrm{cm}^{2}\right)$ da superfície do órgão. Os valores são aproximados, uma vez que a 
área da superfície externa varia com o grau de distensão do órgão. Contudo, os valores representam um bom indicador das diferenças relativas na densidade neuronal em várias partes do TGI (GABELLA, 1979). Assim, a densidade neuronal segue a seguinte ordem, do maior para o menor: colon > duodeno > jejuno-ileo (KARAOSMANOGLU et al., 1996). Ainda, maior densidade é verificada em pequenos animais do que em grandes (GABELLA, 1990).

Inúmeras técnicas têm sido propostas para a marcação completa dos neurônios, como as colorações com corantes básicos em tecido fixado (azul de toluidina, azul de metileno e prata) (GABELLA, 1979), a imuno-histoquimica utilizando o marcador neuronal PGP 9.5 - "protein gene product" (BELAI; COOPER; BURNSTOCK, 1995; JOHNSON et al., 1998; TAKAHASHI et al., 2000; SIOU; BELAI; BURNSTOCK, 1994), o marcador cuprolinic blue (HOLST; POWLEY, 1995; KARAOSMANOGLU et al, 1996; VAN GINNEKEN et al., 1999) e o marcador NCB - "nerve cell body" (FURNESS et al., 1994), e as técnicas de coloração histoquímica NADH (ARAUJO et al., 2003; GABELLA, 1989) e Giemsa (ARAÚJO et al., 2003). De acordo com Young et al. (1993), a utilização da coloração com NADH não evidencia todos os neurônios. Da mesma forma, PGP 9.5 também falha em corar 100\% dos neurônios (EAKER; SALLUSTIO, 1994), levando a uma subestimação dos resultados (JOHNSON et al.,1998).

As alterações na quantidade de neurônios com o envelhecimento são discutíveis. Análises semi-quantitativas com Western blot utilizando PGP 9.5 revelaram que a expressão deste marcador não diminui com a idade no colo médio de ratos, sugerindo que o avanço da idade não esteja associado com uma redução significante no número de neurônios (TAKAHASHI et al., 2000). Da mesma maneira, Johnson et al. (1998) não 
observaram diminuição significativa na quantidade de neurônios no intestino delgado de ratos idosos quando comparados com ratos jovens utilizando o marcador PGP 9.5. Entretanto, este trabalho foi conduzido com a utilização de uma dieta com restrição calórica, podendo este dado estar vinculado a não perda de neurônios.

Diferentemente, Santer e Baker (1988) descreveram que no intestino delgado (jejuno e íleo) e no intestino grosso (colo e reto) de ratos ocorre uma significativa diminuição na densidade neuronal, quando comparam-se animais de seis meses com animais de 24 meses. A diminuição é mais pronunciada no colo, perfazendo $64 \%$.

Da mesma forma, Gabella (1989) relata que o número total de neurônios mioentéricos no intestino delgado de cobaias senis, estimado pela média da densidade neuronal e área da superfície total, representou 40-60\% daquele obtido em adultos jovens. De acordo com o autor, a perda neuronal é acompanhada por mudanças estruturais e por uma reorganização dos neurônios sobrevivente, liderando a sugestão de que a perda neuronal deve ser parte integrante da história programada dos neurônios.

Ainda, Phillips, Kieffer e Powley (2003) relatam uma diminuição neuronal significativa na região do intestino delgado (duodeno, jejuno e íleo) e grosso (colo e reto) de ratos com o envelhecimento. No intestino grosso, aproximadamente $39 \%$ dos neurônios morrem aos 24 meses. A perda neuronal, de acordo com os autores, é caracterizada por um processo degenerativo que resulta eventualmente em declínio da função. Ainda, esta perda neuronal refere-se a específicos fenótipos. 
Menor quantidade de neurônios por gânglio também foi observada no colo de camundongos. Animais de 12 e 24 meses de idade apresentam menos neurônios do que os de três meses (EL-SALHY; SANDSTRÖM; HOLMLUND, 1999).

Uma significativa redução no número de células da glia ocorre juntamente com a redução neuronal durante o envelhecimento. Tais fenômenos podem estar associados e juntos resultarem em distúrbios na função gastrointestinal (PHILLIPS; KIEFFER; POWLEY, 2004).

A perda neuronal varia de acordo com o órgão estudado. Nenhuma perda neuronal é relatada no estômago, diferente do que é referido para o intestino delgado e para o intestino grosso. Ainda, um gradiente para a perda neuronal é observado de regiões orais para anais, isto é, a perda celular no estômago é menor que no intestino delgado, que é menor que no intestino grosso. Ainda, dentro de um órgão, há graus regionais de perda neuronal e estes não são uniformes (PHILLIPS; KIEFFER; POWLEY, 2003).

Doenças como a disautonomia familiar, desordem autossômica de caráter recessivo caracterizada por uma sintomatologia decorrente de alteração no sistema nervoso periférico (BAR-SHAl et al., 2004) e a constipação crônica de origem idiopática (CORTESINI et al., 1995) levam a diminuição na densidade neuronal e no número de gânglios mioentéricos. 


\subsection{ULTRA-ESTRUTURA NEURONAL}

Ultra-estruturalmente, os gânglios mioentéricos apresentam uma estrutura compacta, sendo constituídos por células (células da glia e neurônios) e seus processos. O formato e a espessura destes gânglios mudam de acordo com a contração muscular adjacente (GABELA, 1995).

O gânglio mioentérico não é subdividido em unidades constituintes. Uma única lâmina basal envolve todo o gânglio e nenhuma fibrila de colágeno, fibroblastos, células intersticiais ou vaso sanguíneo são encontrados dentro do gânglio, e sim em torno do gânglio (GABELLA, 1990, 1995; SAFFREY, 2004).

As células gliais não formam um envoltório individual em torno dos neurônios, mas se estendem por todo o gânglio, preenchendo todos os espaços. Apenas um estreito espaço se mantém entre as membranas adjacentes. Os processos das células da glia e dos neurônios constituem o neurópilo (GABELLA, 1990), sendo os gânglios mioentéricos caracterizados por um denso neuropil (SAFFREY, 2004)

Os neurônios ganglionares apresentam um formato irregular. Caracteristicamente, parte do pericário alcança a superfície do gânglio, e sua membrana está em contato direto com a lâmina basal. Sinapses axossomática e axodendrítica são numerosas (GABELLA, 1995).

Sinais ultraestruturais de degeneração não são incomuns nos neurônios mioentéricos e nos respectivos processos nervosos em animais senis, embora limitados 
para células únicas onde o gânglio como um todo demonstra uma estrutura bem preservada (GABELLA, 1989). O aumento de elastina e de colágeno em torno do gânglio é descrito com o envelhecimento (GOMES et al., 1997).

\subsection{ATIVIDADE FÍSICA}

Um programa de atividade física aeróbico contribui para a saúde em um todo, isto é, melhora o humor, a qualidade de vida, reduz os sintomas de ansiedade e depressão e está comumente associada com a melhora no funcionamento de vários sistemas, como o sistema cardiovascular (MCARDLE, 1998), o sistema nervoso central (ARIDA et al., 2004a; ARIDA et al., 2004b; BRAZEL; RAO, 2004; CHURCHILL et al., 2002; NEEPER et al., 1996), o sistema nervoso autônomo central e o sistema endócrino (GILBERT, 1995). Evidências clínicas sugerem que o exercício físico ou a falta deste deva também influenciar a função do sistema digestório (DAPOIGNY; SARNA, 1991).

Um programa de atividade física é capaz de prevenir doenças crônicas e degenerativas entre pacientes idosos (SKALICKY; LITTITZ; VIIDIK, 1996). Por outro lado, o exercício e uma dieta balanceada (redução de calorias) pode reduzir os riscos das mesmas (MATTSON, 2000). Além de um efeito benéfico para a saúde, é descrito na literatura um aumento no tempo de vida. Animais de laboratório têm a expectativa de 
vida aumentada em três a quatro meses quando exercem a atividade física (GOODRICK , 1980; HOLLOSZY et al., 1985).

A constipação é uma complicação que freqüentemente acomete pessoas idosas e sedentárias (DONALD et al., 1985; SARNA, 1991). Assim, o exercício físico poderia contribuir para solucionar tal problema (BOCKUS, 1985; RAO et al., 1999), embora seja relatado que um programa de atividade física intenso, como aquele exercido por corredores de longa distância (maratonistas), pode causar diarréia, sangramento gastrointestinal, dor abdominal, náuseas e vômito (RIDDOCH; TRINICK, 1998). Tais sintomas podem ser atribuídos a uma possível isquemia experimentada com o exercício máximo (CANTWELL, 1981), ou mesmo, a uma possível hipertrofia do músculo psoas maior, liderando a compressão do colo durante a corrida (DAWSON; KHAN; SHREEVE, 1985).

$\mathrm{Na}$ porção superior do TGI, os efeitos da atividade física no esvaziamento gástrico são conflitantes. Dependendo da composição do alimento, da intensidade do exercício e do método de mensuração, a média de esvaziamento pode ser acelerada (MOORE; DATZ; CHRISTIAN, 1990), normal (FORDTRAN; SALTIN, 1967) ou retardada (CAMMACK et al., 1982). Também na porção inferior do trato, os efeitos da atividade física na motilidade colônica são controversos. Alguns trabalhos relatam a existência de aumento na motilidade (DAPOIGNY; SARNA, 1991; VAN LIERE; HESS; EDWARDS, 1954; YOUNG; RICE; STEINHAUS, 1932) enquanto outros não observam efeito algum (BINGHAM; CUMMINGS, 1989; ROBERTSON et al., 1993). 
Ainda, alguns trabalhos descrevem aumento na motilidade colônica após a atividade física, o que pode ser explicado pelo fato que durante o exercício físico as funções corpóreas viscerais ficam sob domínio da atividade simpática. Esta, além de aumentar as freqüências respiratória, cardíaca e a pressão sanguínea sistólica, é responsável por desviar o fluxo sanguíneo dos intestinos para a musculatura esquelética e pele. A redução do fluxo sanguíneo deve inibir a função intestinal durante o exercício. Após este, a atividade simpática diminui, e o fluxo sanguíneo é restaurado, melhorando a motilidade (RAO et al., 1999).

Variações fisiológicas regionais também são relatadas com a atividade física. Assim, foi descrito que os colos transverso e descendente apresentam uma menor atividade durante o exercício do que a região do colo sigmóide e do reto (RAO et al; 1999).

A intensidade da atividade física, associada à freqüência e a duração são fatores importantes para se promover possíveis mudanças fisiológicas. Contudo, um aumento na intensidade, isto é, um exercício mais intenso, poderia ter um maior impacto no trânsito colônico, podendo assim ser útil no tratamento da constipação. (MESHKINPOUR et al., 1998). 
MATERIAL EMÉTODOS 


\section{MATERIAL E MÉTODOS}

Neste capítulo estão relatados o material e os diferentes métodos que foram utilizados para a realização deste trabalho.

\subsection{MATERIAL}

Foram coletados 60 colos $(n=60)$ provenientes de ratos (Rattus norvegicus) da linhagem Wistar, machos, oriundos do Biotério Central da Universidade Federal de São Paulo (UNIFESP). Os animais foram reunidos em três diferentes grupos:

x GRUPO A: 20 ratos adultos (seis meses de idade).

x GRUPO B: 20 ratos de meia idade sedentários (12 meses de idade).

× GRUPO C: 20 ratos de meia idade submetidos à atividade física (12 meses de idade).

Cada grupo ( $A$, B e C) foi subdividido, de acordo com o método a ser utilizado, em quatro diferentes subgrupos:

× Subgrupo MICROSCÓPICO: colos submetidos ás técnica de microscopia de luz convencional $(n=15)$ e de cortes semi-finos e microscopia eletrônica de transmissão $(n=15)$ 
× Subgrupo NADH: colos submetidos à técnica histoquímica da NADH-diaforase $(n=15)$.

× Subgrupo NADPH: colos submetidos à técnica histoquímica da NADPHdiaforase $(n=15)$.

Os animais foram alojados em caixas de polipropileno providas de bebedouro e comedouro, mantidos em condições ambientais controladas de temperatura $\left(22-24^{\circ} \mathrm{C}\right) \mathrm{e}$ de iluminação (ciclo de 12 horas claro e 12 horas escuro). Para todos os grupos foi fornecida ração comercial referência para ratos (Nuvital ${ }^{\circledR}$ ) e água ad libitum. Os procedimentos utilizados nesta investigação científica foram conduzidos em acordo com os princípios éticos de experimentação animal da Comissão de Bioética da Faculdade de Medicina Veterinária e Zootecnia da Universidade de São Paulo (Protocolo $\mathrm{n}^{\circ}$ 463/2004).

\subsection{MÉTODOS}

Os métodos foram aplicados em oito diferentes etapas: protocolo experimental de atividade física (protocolo de atividade física para os animais do grupo $\mathrm{C}$ e protocolo de atividade física para os animais do grupo B), eutanásia dos animais, processamento do material para o estudo histológico (microscopia de luz convencional, microscopia de luz de cortes semi-finos e microscopia eletrônica de transmissão), processamento do material para as técnicas histoquímicas de NADH-diaforase e NADPH-diaforase 
(técnica histoquímica de NADH-diaforase e técnica histoquímica de NADPH-diaforase), obtenção dos preparados de membrana, estudo quantitativo (densidade neuronal e estimativa do número total de neurônios), estudo morfométrico (área dos perfis neuronais e espessura da camada muscular) e análise estatística.

\subsubsection{Protocolo Experimental De Atividade Física}

O programa de atividade física foi instituído apenas para os animais do grupo $B$ (ratos de meia idade sedentários) e do grupo $\mathrm{C}$ (ratos de meia idade submetidos à atividade física).

Os ratos iniciaram o programa de atividade física (corrida) em esteira ergométrica (Inbrasport $^{\circledR}$ ) a partir dos seis meses de idade (180 dias) até os 12 meses (360 dias) de idade. Contudo, estes animais foram inicialmente habituados à atividade física em esteira, durante duas semanas, para depois se iniciar o protocolo experimental. Ainda, de acordo com a performance na esteira, cada animal foi classificado por meio de uma escala de 1-5. Os animais classificados como um (1) eram aqueles que se recusaram a correr, como dois (2) aqueles abaixo da média de corredores (esporádico, para e corre, corre em direção errada), como três (3) os corredores médio, como quatro (4) aqueles acima da média de corredor (corredor consistente, mas ocasionalmente retrocede na esteira) e como cinco (5) os excelentes corredores (mantém consistentemente na esteira) (DISHMAN et al.,1988). Apenas os animais classificados como três (3) ou maior 
que este (4 e 5) foram incluídos nos grupos de estudos (Grupo B e C). Os animais classificados como um ou dois (1 ou 2) foram excluídos do experimento.

4.2.1.1 Protocolo de Atividade Física para os Animais do Grupo C

Os animais do grupo $\mathrm{C}$ realizaram um programa de atividade física intenso, isto é, praticaram a atividade física (corrida) cinco vezes por semana.

Para determinar a intensidade do exercício físico aplicado, os animais do grupo C foram primeiramente submetidos ao teste de esforço máximo. Assim, para a instituição do protocolo inicial foi necessário um primeiro teste de esforço máximo, onde a velocidade inicial da esteira foi de $0,3 \mathrm{Km} / \mathrm{h}$ (ou $5 \mathrm{~m} / \mathrm{min}$ ) e a cada quatro minutos a velocidade foi aumentada na mesma proporção $(0,3 \mathrm{Km} / \mathrm{h})$, conforme o protocolo de Silva et al. (1997). A média das velocidades máxima em que cada animal conseguiu correr na esteira correspondeu à velocidade máxima média do exercício.

Foram realizados seis testes de esforço máximo nos animais (um teste/mês de experimento) para a manutenção do protocolo de exercício. Desta forma, o protocolo de atividade física para este grupo de animais variou mensalmente de acordo com os resultados obtidos nos testes de esforço máximo. Assim, na primeira semana após o teste, os animais foram submetidos à atividade física com duração de 30 minutos, na segunda semana com duração de 40 minutos, na terceira semana com duração de 50 minutos e na quarta semana com duração de 60 minutos. A velocidade máxima 
estipulada no protocolo de atividade física correspondeu a $60 \%$ da velocidade média máxima do exercício. Um sétimo teste de esforço foi realizado antes do sacrifício dos animais, para saber a eficiência do treinamento.

Em cada teste de esforço máximo, foi realizada a pesagem dos animais. Assim sendo, sete pesagens foram realizadas.

\subsubsection{Protocolo de Atividade Física para os Animais do Grupo B}

Os animais do grupo B desenvolveram atividade física somente uma vez por semana e com duração de dez minutos. A velocidade estabelecida para este grupo foi a menor cabível, isto é, $0,3 \mathrm{Km} / \mathrm{h}$, apenas para este grupo de animais não perder a habilidade para correr.

Da mesma forma que os animais do Grupo C, os animais do grupo B foram submetidos a sete testes de esforço máximo e a sete correspondentes pesagens. 


\subsubsection{Eutanasia dos Animais}

Ao final do experimento (Grupo $A=$ seis meses; Grupos $B$ e $C=12$ meses), os animais foram sacrificados com dose letal de anestésico (Tiopental ${ }^{\circledR}-40 \mathrm{mg} / \mathrm{kg}$, via intraperitoneal). Contudo, previamente ao sacrifício, os animais foram submetidos a jejum de 12 horas, para controlar o grau de distensão do trato gastrointestinal (TGI).

\subsubsection{Processamento do Material para o Estudo Histológico}

O estudo histológico foi dividido em três técnicas: microscopia de luz convencional, microscopia de luz de cortes semi-finos e microscopia eletrônica de transmissão. Para o processamento destas técnicas, os animais tiveram o sistema circulatório lavado com uma solução contendo salina tamponada fosfatada (PBS) $\left(\right.$ Sigma $\left.^{\circledR}\right)$ a 0,1 M e pH 7,4 e heparina a $2 \%\left(\right.$ Roche $\left.^{\circledR}\right)$ previamente. Para a lavagem, as veias jugulares foram seccionadas e uma cânula foi inserida no ventrículo esquerdo, permitindo a completa lavagem do sistema. 


\subsubsection{Microscopia de Luz Convencional}

Após a lavagem, uma solução fixadora constituída por formoldeido a 10\% (Sigma ${ }^{\circledR}$ ) foi perfundida nos animais destinados ao estudo histológico por meio da microscopia de luz convencional. A perfusão foi realizada através do mesmo orifício utilizado para a lavagem do sistema circulatório. Contudo, para a perfusão das soluções fixadoras, as veias jugulares foram previamente laqueadas. A seguir, a cavidade abdominal foi exposta (celiotomia na linha alba) para evidenciar o colo (limite cranial - junção ceco-cólica, limite caudal esfíncter anal) e permitir sua retirada do abdome.

Depois de retirado, o colo foi seccionado transversalmente em planos macroscópicos paralelos e seriados, com a utilização de uma lâmina cortante, originando seis diferentes fatias consecutivas (três no colo ascendente e três no colo descendente). A distância média entre as fatias foi de $20 \mathrm{~mm}$ e cada fatia apresentava em média $10 \mathrm{~mm}$ de comprimento. Após, os fragmentos foram fixados por imersão na mesma solução fixadora perfundida, por um período mínimo de 72 horas.

Posteriormente, os fragmentos foram desidratados em série crescente de etanol $(70 \%$ em 1 hora, $80 \%$ em 1 hora, 90\% em 1 hora e 100\% em 3 trocas de 1 hora cada), diafanizados em xilol (2 trocas de 30 minutos cada) e embebidos e incluídos em Paraplast (Sigma $\left.{ }^{\circledR}\right)$. A inclusão dos três fragmentos de cada colo (ascendente e descendente) se deu no mesmo bloco, tendo o cuidado de manter a orientação de cada fragmento. Assim, foram obtidos dois blocos por animal, sendo cada bloco constituído por três fragmentos separados por uma distância conhecida. Em seguida os blocos foram seccionados com $5 \mu \mathrm{m}$ de espessura, 
corados com hematoxilina-eosina, cobertos com resina Permount (Synth ${ }^{\circledR}$ ) e montados sob lamínula.

4.2.3.2 Microscopia de Luz de Cortes Semi-Finos e Microscopia Eletrônica de Transmissão

Após a lavagem, uma solução fixadora constituída por glutaraldeído a 5\% $\left(\right.$ Merck $\left.^{\circledR}\right)$ e formoldeido a $1 \%\left(\right.$ Sigma $\left.^{\circledR}\right)$ em tampão cacodilato de sódio $\left(\mathrm{EMS}^{\circledR}\right)$ a $0,125 \mathrm{M}$ e pH 7.4 (solução fixadora de Karnovsky modificada) foi perfundida nos animais. A perfusão, assim como a retirada do colo do abdome, procedeu-se da mesma forma descrita para a microscopia de luz convencional.

Pequenos fragmentos do colo ascendente e descendente foram coletados. Estes foram lavados com solução salina para a remoção do conteúdo fecal e, posteriormente, acondicionados em recipientes contendo a mesma solução fixadora utilizada na perfusão, por um período mínimo de 72 horas, promovendo a fixação por imersão.

Depois os fragmentos foram lavados em solução tampão de cacodilato de sódio $\left(E S^{\circledR}\right)$ a 0,125M e pH 7,4 e imersos em uma solução aquosa de tetróxido de ósmio $\left(\mathrm{EMS}^{\circledR}\right)$ a $2 \%$. As amostras permaneceram nesta solução durante 60 minutos, no escuro e sob agitação constante. Em seguida, foram lavados na mesma solução de tampão de cacodilato anteriormente referida, seguido de água destilada, para serem contrastados em blocos com a 
solução aquosa saturada de acetato de uranila $\left(\right.$ Reagen ${ }^{\circledR}$ ) durante 60 minutos sob agitação constante e em recipiente escuro.

Os fragmentos foram lavados com água destilada e desidratados em série crescente de etanóis (50\% em 10 minutos, $70 \%$ em 10 minutos, 90\% em 10 minutos e $100 \%$ em 20 minutos), sendo depois desidratados em óxido de propileno $\left(\mathrm{EMS}^{\circledR}\right)$ por 10 minutos. As amostras foram embebidas com uma solução de óxido de propileno $\left(\mathrm{EMS}^{\circledR}\right)$ e resina araldite (502 Polyscience Inc. ${ }^{\circledR}$ ), em constante agitação e em diferentes proporções. Após estas etapas, os espécimes foram transferidos para resina araldite pura (502 Polyscience Inc. ${ }^{\circledR}$ ) e levados à estufa $\left(60^{\circ} \mathrm{C}\right)$, permanecendo durante um período mínimo de dois dias.

Os blocos de resina formados foram trimados e posteriormente seccionados com navalha de vidro a $2 \mu \mathrm{m}$ de espessura. A seguir, as secções semi-finas foram coletadas sobre lâminas e coradas com uma solução de azul de toluidina alcoólica. Em seguida, foram cobertas com uma gota de araldite (502 Polyscience Inc. ${ }^{\circledR}$ ) e montados sob lamínula, possibilitando o estudo da microscopia de luz de cortes semi-finos.

Para o estudo da microscopia eletrônica de transmissão, os mesmos blocos usados para o estudo da microscopia de luz de cortes semi-finos foram utilizados. Contudo, os blocos foram trimados novamente, na região de interesse, e secções de 70 a $90 \mathrm{~nm}$ de espessura foram obtidas por meio de navalha de diamante. As secções foram colocadas em placas de cobre e coradas com acetato de uranila (Reagen ${ }^{\circledR}$ ) a $3 \%$ e citrato de chumbo $\left(\operatorname{Sigma}^{\circledR}\right)$, sendo examinadas em microscópio eletrônico de transmissão. 


\subsubsection{Processamento do Material para as Técnicas Histoquímicas de NADH- Diaforase e NADPH-Diaforase}

Os animais destinados para as técnicas histoquímicas de $\mathrm{NADH}$-diaforase e NADPH-diaforase, após o sacrifício, tiveram o colo retirado do abdome por meio de uma celiotomia na linha alba (limite cranial - junção ceco-cólica, limite caudal - esfíncter anal) e posteriormente mensurado o seu comprimento com o auxílio de régua milimetrada. Em seguida, o colo foi decalcado em uma de suas faces em papel branco, para a determinação da área de superfície colônica. Os desenhos obtidos foram escaneados juntamente com uma escala de papel milimetrado e a área foi determinada por meio do software analisador de imagem específico (Image Pro-Plus 3.0.1 ${ }^{\circledR}$ ).

\subsubsection{Técnica Histoquímica de NADH-Diaforase (Gabella,1969)}

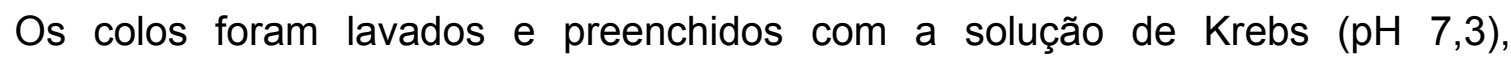
constituída por $1,3 \mathrm{~g}$ de bicarbonato de sódio $\left(\mathrm{NaHCO}_{3}\right)\left(\operatorname{Sinth}^{\circledR}\right), 0,24 \mathrm{~g}$ de cloreto de magnésio $\left(\mathrm{MgCl}_{2} \cdot 6 \mathrm{H}_{2} \mathrm{O}\right)\left(\mathrm{Sinth}^{\circledR}\right), 0,44 \mathrm{~g}$ de cloreto de potássio $(\mathrm{KCl})\left(\mathrm{Sinth}^{\circledR}\right), 0,165 \mathrm{~g}$ de hipofosfato de sódio $\left(\mathrm{NaH}_{2} \mathrm{PO}_{2}\right)\left(\operatorname{Sinth}^{\circledR}\right), 7,05 \mathrm{~g}$ de cloreto de sódio $(\mathrm{NaCl})\left(\mathrm{Sinth}^{\circledR}\right)$ e $0,27 \mathrm{~g}$ de cloreto de cálcio $\left(\mathrm{CaCl}_{2}\right)$ em 1 litro de água destilada $\left(\mathrm{Sinth}^{\circledR}\right)$. A seguir, foram imediatamente submetidos ao procedimento para evidenciar neurônios, que compreendeu duas lavagens de 10 minutos cada em solução de Krebs, seguida da 
permeabilização em Krebs contendo Triton X-100 (Sigma $\left.{ }^{\circledR}\right)$ a 0,3\% durante cinco minutos. Após, mais duas lavagens de 10 minutos cada em Krebs foram realizadas, para posterior incubação em meio de reação constituído por $25 \mathrm{ml}$ de solução estoque de Nitro Blue Tetrazolium (NBT, solução estoque na concentração de $0,5 \mathrm{mg} / \mathrm{ml}$ ) $\left(\right.$ Sigma $\left.^{\circledR}\right), 25 \mathrm{ml}$ de tampão fosfato de sódio $\left(\operatorname{Sinth}^{\circledR}\right)(0,1 \mathrm{M} ; \mathrm{pH} 7,3), 50 \mathrm{ml}$ de água destilada e 0,05 g de $\beta-\mathrm{NADH}\left(\right.$ Sigma $\left.^{\circledR}\right)$.

O desenvolvimento da reação histoquímica foi controlado visualmente com o auxílio do estereomicroscópio $\left(\right.$ Tecnival $^{\circledR}$ ). A incubação durou em média 45 minutos. Após, os colos foram abertos e fixados em solução de formoldeido a $10 \%$ em tampão fosfato de sódio $\left(\right.$ Sigma $\left.^{\circledR}\right)(0,1 \mathrm{M} ; \mathrm{pH} 7,3)$.

4.2.4.2 Técnica Histoquímica de NADPH-Diaforase (Scherer-Singler et al., 1983)

Os colos foram lavados e preenchidos com a solução de Krebs pH 7,3 (1,3g de $\mathrm{NaHCO}_{3}-\operatorname{Sinth}^{\circledR}, 0,24 \mathrm{~g}$ de $\mathrm{MgCl}_{2}, 6 \mathrm{H}_{2} \mathrm{O}-\operatorname{Sinth}^{\circledR}, 0,44 \mathrm{~g}$ de $\mathrm{KCl}-\operatorname{Sinth}^{\circledR}, 0,165 \mathrm{~g}$ de $\mathrm{NaH}_{2} \mathrm{PO}_{2}-$ Sinth $^{\circledR}, 7,05 \mathrm{~g}$ de $\mathrm{NaCl}-$ Sinth $^{\circledR}$ e $0,27 \mathrm{~g}$ de $\mathrm{CaCl}_{2}-$ Sinth $^{\circledR}$ em 1 litro de água destilada). Em seguida, para evidenciar os neurônios, os colos foram submetidos a duas lavagens em solução de Krebs (10 minutos cada) seguidas de permeabilização em Krebs contendo Triton X-100 $\left(\right.$ Sigma $\left.^{\circledR}\right)$ a $0,3 \%$ dissolvido em tampão fosfato de sódio (PBS) $\left(\right.$ Sigma $\left.^{\circledR}\right)(\mathrm{pH} 7,3)$ durante 10 minutos. Depois, mais duas lavagens em salina tamponada fosfatada (PBS) durante 10 minutos cada foram necessárias para 
posterior incubação em meio de reação constituída por 50mg de NBT (Sigma ${ }^{\circledR}$ ), 100mg de $\beta$-NADPH $\left(\right.$ Sigma $\left.^{\circledR}\right)$ e $0,3 \%$ de Triton X-100 ${ }^{\circledR}\left(\right.$ Sigma $\left.^{\circledR}\right)$ em tampão Tris-HCl (Sigma $\left.{ }^{\circledR}\right)$ $(0,1 \mathrm{M} \mathrm{pH} \mathrm{7,6)} \mathrm{(duas} \mathrm{horas).}$

O desenvolvimento da reação histoquímica foi controlado visualmente com o auxílio de estereomicroscópio $\left(\right.$ Tecnival $^{\circledR}$ ). A incubação durou em média duas horas. Após, os colos foram abertos e imersos em solução de formaldeído a $4 \%$, para a fixação e armazenagem.

\subsubsection{Obtenção dos Preparados de Membrana}

Foram coletados quatro diferentes fragmentos do colo (dois fragmentos da porção ascendente e dois fragmentos da porção descendente). Os fragmentos coletados apresentavam aproximadamente $15 \mathrm{~mm}$ de comprimento e foram coletados de maneira sistemática, permitindo que todos os fragmentos fossem eqüidistantes entre si. Os fragmentos, após a coloração, foram abertos cuidadosamente pela sua borda mesentérica. A mucosa e a submucosa foram microdissecadas com o auxílio de estereomicroscópio $\left(\right.$ Tecnival $^{\circledR}$ ) (aumento de 4X). Os fragmentos foram montados entre lâmina e lamínula com glicerina $\left(\operatorname{Sinth}^{\circledR}\right)$ tamponada em tampão fosfato de sódio $\left(\right.$ Sigma $\left.^{\circledR}\right)$. 
Problemas no processamento foram responsáveis pela perda de um animal do grupo B (ratos de meia idade sedentários) quando utilizado a técnica histoquímica de $\mathrm{NADH}$-diaforase.

\subsubsection{Estudo Quantitativo}

O estudo quantitativo foi dividido em duas etapas: determinação da densidade neuronal e estimativa do número total de neurônios.

\subsubsection{Densidade Neuronal}

A densidade neuronal, neste trabalho definida como número de neurônios por unidade de área (unidade utilizada: $\mathrm{mm}^{2}$ ), foi calculada por meio dos quatro preparados de membrana (dois da porção ascendente do colo e dois da porção descendente do colo) escolhidos sistematicamente e aleatoriamente por todo o comprimento do colo, como descrito anteriormente. A quantificação neuronal foi realizada com o auxílio do microscópio Olympus $B \times 60^{\circledR}$ (objetiva 40X) e da câmara digital Axio Cam HRc - Zeiss ${ }^{\circledR}$, na qual a imagem era capturada e transferida para a tela de um computador, permitindo desta forma a contagem dos perfis neuronais na tela. 
A imagem do campo verificada na tela do computador foi delimitada por uma área teste, constituída por linhas de inclusão (margem superior e margem direita) e exclusão (margem inferior e margem esquerda), sendo considerados apenas os perfis neuronais que estavam dentro da área teste e que não tocavam as linhas de exclusão. Tal procedimento permite uma igual chance de amostragem dos neurônios, independente do tamanho destes. Os neurônios que tocaram a margem inferior e direita do campo de análise foram excluídos, e os que tocaram as extremidades opostas foram contados.

Os campos de análise foram estabelecidos por meio de um sistema teste adaptado para cada preparado de membrana. Em cada preparado, foram estabelecidos 21 campos. Baseado na largura do preparado de membrana (aproximadamente 15mm), os 21 campos foram distribuídos como três colunas com sete áreas cada, permitindo amostrar todas as regiões (mesentérica e antimesentérica) do preparado de membrana. Assim, foram analisados 42 campos por colo, totalizando 84 campos por toda a extensão do colo.

Em virtude do colo, assim como todo o intestino, variar em sua circunferência, um sistema teste de amostragem retangular com dimensões fixadas não pode ser adequado neste material. Assim um ajustamento para cada coluna dentro do preparado de membrana foi necessário. Contudo, os pontos das colunas foram sempre ajustados de maneira que sempre mantiveram a mesma distancia entre si (JARVINEN et al., 1999). 
Para realizar o cálculo da densidade neuronal, é descrito na literatura especializada a utilização de alguns fatores de correção. O primeiro fator de correção relaciona-se com a faixa etária dos animais estudados, uma vez que é relatado que os animais mais velhos podem apresentar comprimento e largura dos intestinos maiores do que os animais jovens, gerando conseqüentemente uma "diluição neuronal", isto é, a redução do número de neurônios por unidade de área nos animais mais velhos (GABELLA, 1971, 1989; JOHNSON et al., 1998; PHILLIPS; KIEFFER; POWLEY, 2003; PHILLIPS; POWLEY, 2001), o que poderia levar a conclusões errôneas na interpretação dos resultados quando se compara as densidades neuronais entre si. Entretanto, neste trabalho tal fator não foi utilizado, uma vez que nenhuma diferença de área foi verificada nos diferentes grupos etários estudados (seis meses e 12 meses).

O segundo fator de correção, este utilizado neste trabalho, visa evitar as diferenças naturais que há no diâmetro dos fragmentos do intestino e também as diferenças no diâmetro dos intestinos causadas pelas etapas do processamento do material (aumento ou redução da área intestinal). Assim, para a utilização deste fator, antes do processamento do material a área do fragmento foi calculada e depois, após o processamento, foi mensurada novamente, quando o fragmento já estava montado em lâmina (GABELLA, 1971; SOUZA et al., 1993). Deste modo, foi possível verificar a porcentagem do aumento ou diminuição do campo, permitindo a correção dos resultados. 
4.2.6.2 Estimativa do Número Total de Neurônios

A estimativa do número total de neurônios se deu através do produto entre a densidade numérica (neurônios $/ \mathrm{mm}^{2}$ ) utilizando o fator de correção para as alterações no diâmetro dos fragmentos pela área de superfície colônica obtida no início do processamento das técnicas histoquímicas de NADH e NADPH-diaforase, descritas anteriormente.

\subsubsection{Estudo Morfométrico}

O estudo morfométrico foi dividido em duas etapas: determinação área dos perfis neuronais e mensuração da espessura da camada muscular.

4.2.7.1 Área dos Perfis Neuronais

Para mensurar a área dos perfis neuronais, os mesmos campos utilizados para a quantificação foram analisados, permitindo assim uma análise sistemática e aleatória. 
Desta forma, foram analisados 42 campos por colo (ascendente e descendente), totalizando 84 campos por toda a extensão do colo.

As imagens dos campos de análise foram obtidas com o auxílio do microscópio Olympus BX60 ${ }^{\circledR}$ (objetiva 40X) e de uma câmara digital Axio Cam HRc - Zeiss ${ }^{\circledR}$, na qual a imagem era capturada e transferida para a tela de um computador. Após, por meio do software analisador de imagem específico (Image-Pro-Plus 3.0.1 ${ }^{\circledR}$ ), calibrado com o auxílio de uma lâmina de calibragem, o perímetro de cada perfil neuronal foi contornado e, posteriormente, a área seccional foi calculada automaticamente.

O campo de análise foi delimitado por uma área teste constituída por linhas de inclusão e exclusão. Apenas os perfis neuronais que estavam dentro da área teste e que não tocavam as linhas de exclusão foram analisados.

O fator de correção para evitar as diferenças no diâmetro dos intestinos causadas pelas diferenças naturais e pelas etapas do processamento do material também foi utilizado, impedindo desta forma um possível aumento ou diminuição no tamanho real do neurônio (GABELLA, 1971; SOUZA et al., 1993).

\subsubsection{Espessura da Camada Muscular}

Por meio dos cortes histológicos provenientes da microscopia de luz convencional, a espessura das camadas muscular longitudinal e circular foi mensurada 
com o auxílio do software analisador de imagem específico (Image- Pro-Plus 3.0.1 ${ }^{\circledR}$ ), devidamente calibrado com uma lâmina de calibragem. As imagens foram obtidas com o auxílio do microscópio Olympus $B \times 60^{\circledR}$ (objetiva $4 \mathrm{X}$ ) e de uma câmara digital Axio Cam HRc - Zeiss ${ }^{\circledR}$, na qual a imagem era capturadas e transferidas para a tela de um computador.

Cada lâmina foi composta por três fragmentos de cada porção do colo (ascendente e descendente), separados de maneira eqüidistante, como descrito anteriormente. Em cada fragmento, quatro diferentes campos foram mensurados. Assim, em cada colo foram analisados 12 campos, totalizando 24 campos por todo o colo. A escolha do campo para a mensuração se deu por meio de quadrantes. Uma vez que o colo, assim como todo o TGI, apresenta um formato tubular, quatro diferentes campos foram amostrados $\left(0^{\circ}-90^{\circ}, 90^{\circ}-180^{\circ}, 180^{\circ}-270^{\circ}\right.$ e $\left.270^{\circ}-0^{\circ}\right)$. Dentro de cada campo, a maior espessura foi mensurada.

\subsubsection{Análise Estatística}

Para a análise estatística, foi utilizado o software GraphPad Prism $4.1^{\circledR}$. A análise de significância dos resultados de quantificação e morfométricos foi testada usando o procedimento ANOVA para análises de variância e, em caso de detecção de efeitos significativos $(P<0,05)$, utilizou-se o teste de Tukey. Para a análise do peso corpóreo e 
da atividade física foi utilizado o procedimento ANOVA para análises de variância e, em caso de detecção de efeitos significativos $(P<0,05)$, utilizou-se o teste t de Student. 
RESULTADOS 


\section{RESULTADOS}

Os resultados foram reunidos em seis ítens: atividade física, peso corpóreo, anatomia microscópica do plexo mioentérico, aspectos ultra-estruturais, estudo quantitativo (densidade neuronal e estimativa do número total de neurônios) e estudo morfométrico (área dos perfis neuronais e espessura da camada muscular).

\subsection{ATIVIDADE FÍSICA}

Os resultados referentes ao protocolo experimental de atividade física foram descritos apenas nos grupos B (ratos de meia idade sedentários) e C (ratos de meia idade submetidos à atividade física), uma vez que os animais pertencentes ao grupo $\mathrm{A}$ (ratos adultos) não exerceram atividade física.

Nos animais pertencentes ao grupo $B$, a velocidade variou de $0,6-1,2 \mathrm{Km} / \mathrm{h}$ no primeiro teste (média 0,9 Km/h, desvio padrão 0,2; coeficiente de variação $23 \%$ ), variou de $0,6-1,5$ no segundo teste (média $0,8 \mathrm{Km} / \mathrm{h}$, desvio padrão 0,24 ; coeficiente de variação $29,7 \%$ ), variou de $0,6-1,2$ no terceiro teste (média $0,8 \mathrm{Km} / \mathrm{h}$, desvio padrão 0,2; coeficiente de variação $25 \%$ ), variou de 0,3-1,2 no quarto teste (média 0,7 Km/h, desvio padrão 0,21 ; coeficiente de variação de $30 \%$ ), variou de $0,3-1,2$ no quinto teste (média $0,7 \mathrm{Km} / \mathrm{h}$, desvio padrão 0,22 ; coeficiente de variação $32 \%$ ), variou de $0,3-1,2$ no sexto 
teste (média de $0,7 \mathrm{Km} / \mathrm{h}$, desvio padrão 0,25; coeficiente de variação $38 \%$ ) e variou de 0,3-0,9 no sétimo teste (média de $0,6 \mathrm{Km} / \mathrm{h}$, desvio padrão 0,23 ; coeficiente de variação 37\%) (Figura 1).

Nos animais pertencentes ao grupo $C$ a velocidade variou de 0,9-1,2 Km/h no primeiro teste (média $1,0 \mathrm{Km} / \mathrm{h}$, desvio padrão 0,16 ; coeficiente de variação $17 \%$ ), variou de 0,9-1,8 no segundo teste (média 1,2 Km/h, desvio padrão 0,27; coeficiente de variação 23,5\%), variou de 0,9-2,1 no terceiro teste (média 1,3 Km/h, desvio padrão 0,3; coeficiente de variação $23 \%$ ), variou de $0,9-1,8$ no quarto teste (média $1,3 \mathrm{Km} / \mathrm{h}$, desvio padrão 0,3 ; coeficiente de variação $23 \%$ ), variou de $0,9-1,8$ no quinto teste (média 1,2 $\mathrm{Km} / \mathrm{h}$, desvio padrão 0,3 ; coeficiente de variação $24 \%$ ), variou de $0,9-1,8$ no sexto teste (média 1,2 Km/h, desvio padrão 0,3; coeficiente de variação $25 \%$ ) e variou de 0,6-1,8 no sétimo teste (média $1,1 \mathrm{Km} / \mathrm{h}$, desvio padrão 0,32 ; coeficiente de variação $30 \%$ ) (Figura 1).

Os resultados referentes ao protocolo de treinamento diferiram significativamente $(P<0,05)$ entre os grupos $B$ e $C$ a partir do segundo teste (Tabela 1). 


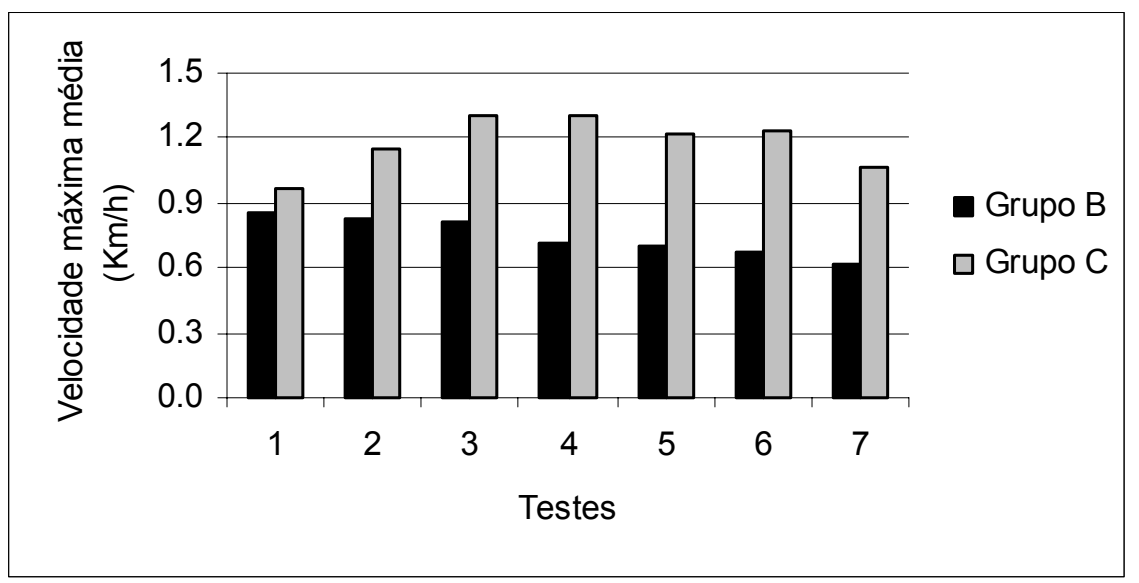

Figura 1 - Velocidade máxima média obtida nos diferentes testes de esforço máximo nos grupos $B$ (ratos de meia idade sedentários) e C (ratos de meia idade submetidos à atividade física)

Tabela 1 - Velocidade máxima média $(\mathrm{Km} / \mathrm{h})$ obtida nos testes de esforço máximo e sua significância estatística

\begin{tabular}{|c|c|c|c|c|c|c|c|}
\hline & $1^{\circ}$ teste & $2^{\circ}$ teste & $3^{\circ}$ teste & $4^{\circ}$ teste & $5^{\circ}$ teste & $6^{\circ}$ teste & $7^{\circ}$ teste \\
\hline Grupo B & $0,9 a$ & $0,8 a$ & $0,8 a$ & $0,7 a$ & $0,7 a$ & $0,7 a$ & $0,6 a$ \\
\hline Grupo C & $1,0 a$ & $1,2 b$ & $1,3 b$ & $1,3 b$ & $1,2 b$ & $1,2 b$ & $1,1 b$ \\
\hline
\end{tabular}

* Médias seguidas por letras diferentes na mesma coluna diferem pelo método de $t$ de Student $(\mathrm{P}<0,05)$.

\subsection{PESO CORPÓREO}

No grupo A o peso corpóreo variou de 365-567g (média 441,6g, desvio padrão 59 e coeficiente de variação 13\%) (Figura 2). 
No grupo B, o peso corpóreo variou de 354-494g na primeira pesagem (média 427g, desvio padrão 47; coeficiente de variação 11\%), variou de 368-536g na segunda pesagem (média de 459g, desvio padrão 46,7; coeficiente de variação 10\%), variou de 386-540g na terceira pesagem (média de 474g, desvio padrão 46; coeficiente de variação $10 \%$ ), variou de 400-578g na quarta pesagem (média de 489g, desvio padrão 49; coeficiente de variação $10 \%$ ), variou de 418-580g na quinta pesagem (média de 505g, desvio padrão 50; coeficiente de variação $10 \%$ ), variou de $376-606 \mathrm{~g}$ na sexta pesagem (média de 511g, desvio padrão 59,7; coeficiente de variação 11,7\%) e variou de 392-584 na sétima pesagem (média de 509g, desvio padrão 49; coeficiente de variação 9\%) (Figura 2).

Nos animais pertencentes ao grupo C, o peso corpóreo variou de 326-464g na primeira pesagem (média 410g, desvio padrão 36; coeficiente de variação $8,7 \%$ ), variou de 338-476g na segunda pesagem (média 423g, desvio padrão 33; coeficiente de variação $8 \%$ ), variou de $374-486$ g na terceira pesagem (média 439g, desvio padrão 37; coeficiente de variação $8 \%$ ), variou de $386-508 \mathrm{~g}$ na quarta pesagem (média 452g, desvio padrão 37 ; coeficiente de variação $8 \%$ ), variou de $380-518 \mathrm{~g}$ na quinta pesagem (média 465,7g, desvio padrão 39; coeficiente de variação $8 \%$ ), variou de $380-530$ g na sexta pesagem (média 469g, desvio padrão 45; coeficiente de variação 9\%) e variou de 360-571 na sétima pesagem (média 464g, desvio padrão 66,7; coeficiente de variação 14,3\%) (Figura 2).

Os resultados referentes ao peso corpóreo diferiram significativamente $(P<0,05)$ entre os grupos $B$ e $C$ a partir da segunda pesagem. O peso corpóreo do grupo A 
diferiu significativamente $(P<0,05)$ do grupo $B$. Nenhuma diferença significativa no peso foi verificada entre os grupos A e C (Tabela 2).

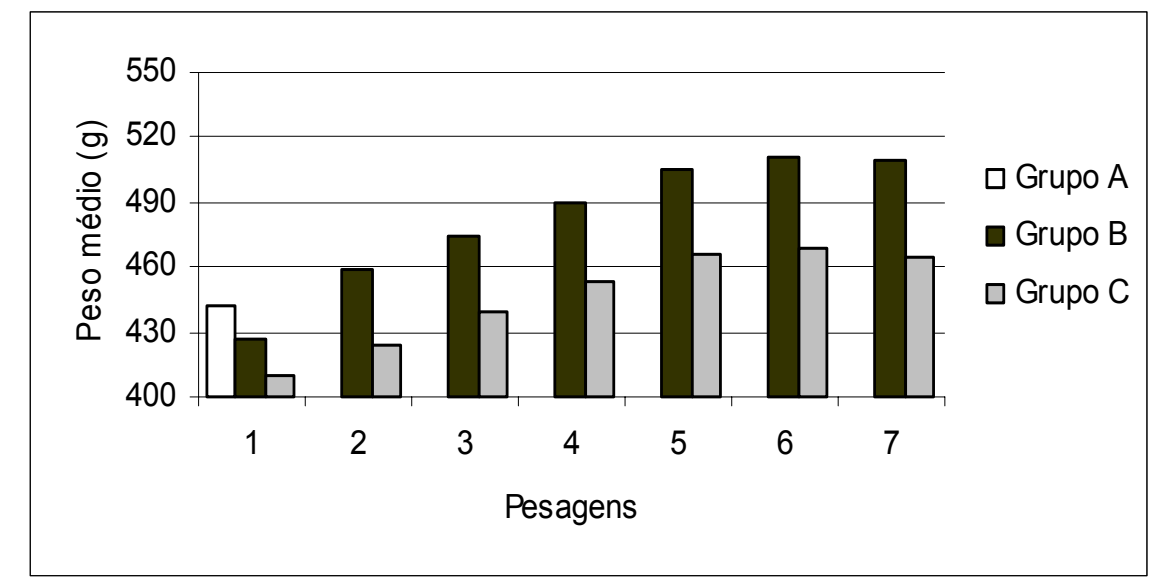

Figura 2 - Média dos pesos corpóreo ( $\mathrm{g}$ ) nas diferentes pesagens nos grupos A (ratos adultos), B (ratos de meia idade sedentários) e C (ratos de meia idade submetidos à atividade física)

Tabela 2 - Média do peso corpóreo (g) e sua significância estatística

$1^{\circ}$ teste $2^{\circ}$ teste $\quad 3^{\circ}$ teste $4^{\circ}$ teste $5^{\circ}$ teste $6^{\circ}$ teste $7^{\circ}$ teste

\begin{tabular}{lrrrrrrr} 
Grupo A & - & - & - & - & - & - & $441 \mathrm{a}$ \\
Grupo B & $427 \mathrm{a}$ & $459 \mathrm{a}$ & $474 \mathrm{a}$ & $489 \mathrm{a}$ & $505 \mathrm{a}$ & $511 \mathrm{a}$ & $509 \mathrm{~b}$ \\
Grupo C & $410 \mathrm{a}$ & $423 \mathrm{~b}$ & $439 \mathrm{~b}$ & $452 \mathrm{~b}$ & $465,7 \mathrm{~b}$ & $469 \mathrm{~b}$ & $461 \mathrm{a}$ \\
\hline
\end{tabular}

* Médias seguidas por letras diferentes na mesma coluna diferem pelo método de $t$ de Student $(\mathrm{P}<0,05)$ 


\subsection{ANATOMIA MICROSCOPICA DO PLEXO MIOENTÉRICO}

As características microestruturais do plexo mioentérico não diferiram entre os grupos estudados (grupos A, B e C). Os neurônios mioentéricos, encontrados entre as túnicas circular e longitudinal da camada muscular (Figura 3A-B), estavam, em maioria, localizados em gânglios, sendo estes freqüentemente alongados e com seu maior eixo orientado na mesma direção da camada circular (Figura 3C-F). Contudo, neurônios no trajeto dos feixes de fibras nervosas foram eventualmente observados (Figura 3E).

Neurônios de vários tamanhos e formas foram vistos nos gânglios tanto na porção ascendente quanto na porção descendente do colo. Os neurônios eram na maioria alongados e com núcleo em forma oval. Entretanto, neurônios de forma arredondados também foram encontrados.

Os gânglios eram conectados uns aos outros por uma malha espessa de fibras nervosas (plexos primários). Feixes nervosos mais finos (plexos secundários) formavam uma malha interligando os feixes primários entre si, e vários ramos finos e fibras nervosas isoladas (plexos terciários) conectando-se entre si (Figura 3F).

O arranjo do plexo mioentérico apresentou algumas diferenças entre as porções ascendente e descendente do colo. Assim, na porção ascendente a distribuição dos gânglios e das fibras nervosas foi heterogênea. A região mesentérica apresentava um denso plexo, isto é, os gânglios estavam mais próximos, sendo conectados por espessas e densas fibras primárias. Já na região antimesentérica os gânglios eram 
mais espaçados em relação uns aos outros e conectados por fibras não tão espessas como na região anteriormente descrita. Na porção descendente a distribuição dos gânglios e das fibras nervosas foi uniforme entre as regiões mesentérica e antimesentérica.

\subsection{ASPECTOS ULTRA-ESTRUTURAIS}

Ultra-estruturalmente, nenhuma diferença marcante entre os grupos $(A, B, C)$ foi verificada nos neurônios dos gânglios mioentéricos. Nos três grupos os neurônios apresentaram membranas citoplasmática e nuclear integras. O núcleo dos neurônios era grande, arredondado ou ovóide, sendo constituído por um proeminente nucléolo e cromatina, sendo esta última constituída por uma maior quantidade de regiões densas (heterocramatina) nos grupos $\mathrm{A}$ (ratos adultos) e $\mathrm{C}$ (ratos de meia-idade submetidos à atividade física). Por outro lado, o grupo B (ratos de meia idade sedentários) apresentou uma maior quantidade de cromatina dispersa (eucromatina) (Figuras 4A-B; 5A-B; 6A-B). No citoplasma, agregados de retículo endoplasmático rugoso, aparelho de Golgi e numerosas mitocôndrias foram facilmente observados em todos os grupos (Figuras 4C; $5 C ; 6 C)$.

Um denso neuropilo (processos neuronais e das células da glia) foi evidenciado em todos os grupos. As terminações nervosas eram constituídas por inúmeras vesículas sinápticas agranulares (colinérgicas) e granulares (contendo neuropeptídeos), 
mitocôndrias, filamentos intermediários (neurofilamentos) e microtúbulos (Figuras 4D; 5D; 6D).

Os gânglios mioentéricos eram envolvidos por tecido conjuntivo e uma delgada membrana basal, sendo esta mais bem delineada nos animais do grupo B do que nos grupos A e C (Figuras 4E; 5E; 6E). Os espaço entre as camadas musculares (espaço periganglionar) apresentou uma espessura semelhante entre os grupos. Entretanto, uma quantidade de colágeno mais agrupado e melhor delineado foi verificada no grupo B (Figuras 4E-F; 5E-F; 6E-F). Fibroblastos (Figuras 4G; 5G; 6G) e capilares também foram evidenciados. 
Figura 3 (A-F) - Fotomicrografias do plexo mioentérico de ratos. A-B: Microestrutura do colo evidenciando a localização do plexo mioentérico entre as túnicas longitudinal (TL) e circular (TC) da camada muscular e os neurônios mioentéricos $(\rightarrow)$ corados com azul de toluidina. C-F: Preparados de membrana do colo com as técnicas histoquímicas de NADHdiaforase (D) e NADPH-diaforase (C, E e F). Gânglio mioentérico evidenciado em $C$ e D. Neurônio no trajeto do feixe nervoso $(\rightarrow)$ é verificado em E. Em F é evidenciado o arranjo do plexo mioentérico 

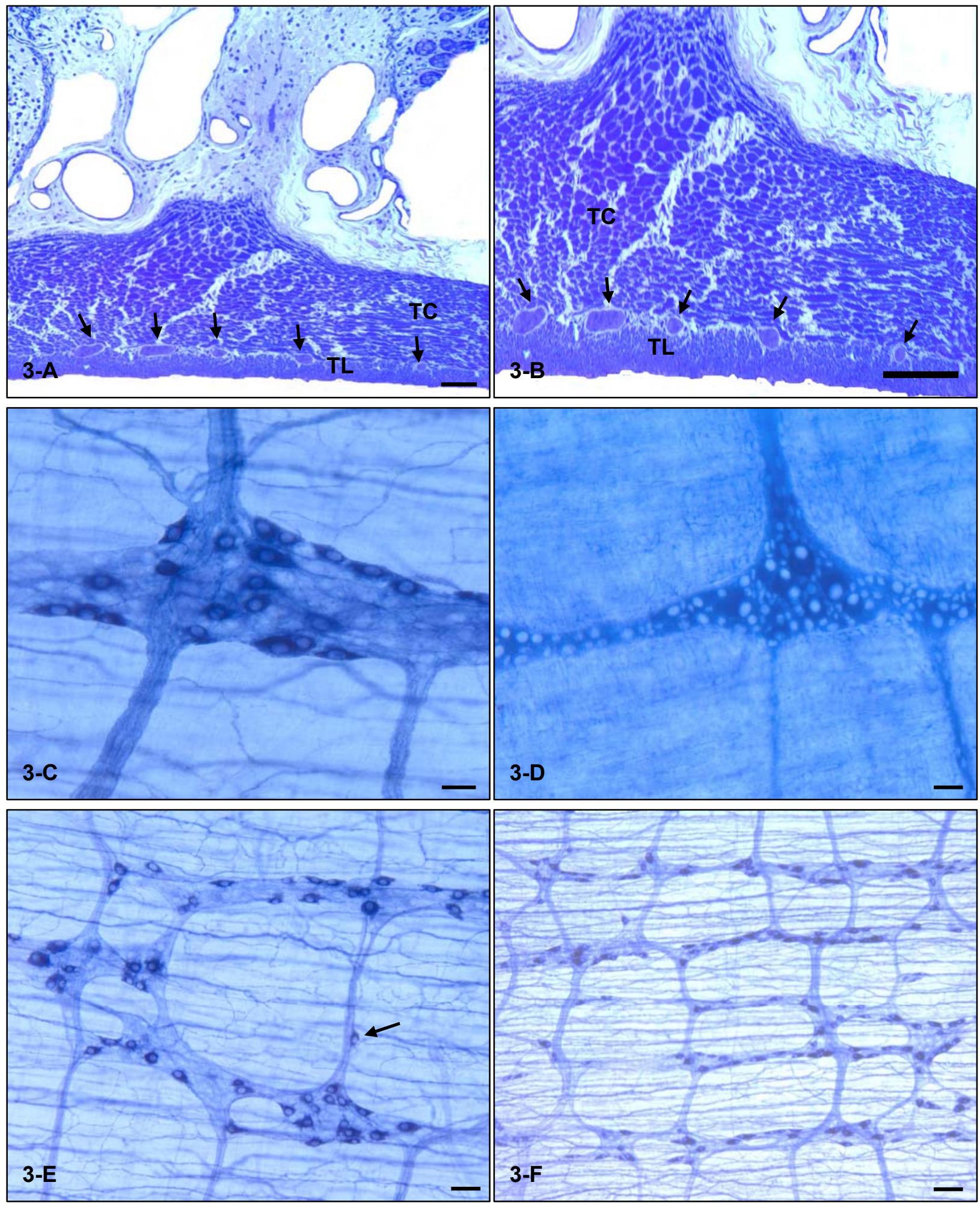
Figura $4(\mathrm{~A}-\mathrm{H})$ - Ultra-estrutura dos gânglios mioentéricos do colo de ratos adultos (Grupo A). A: Núcleo do neurônio (n), delimitado por sua respectiva membrana nuclear (seta), apresentando um formato ovóide. Constituído por um proeminente nucléolo $(n)$ e cromatina. B: Neurônio delimitado por uma integra membrana citoplasmática (cabeça de seta) e seu núcleo por uma correspondente membrana nuclear (seta). Externamente ao neurônio $(\mathrm{N})$, um denso neuropilo. C: Organelas como retículo endoplasmático rugoso (cabeça de seta quadrada), complexo de Golgi (cabeça de seta redonda) e mitocôndrias $\left(^{*}\right)$ no citoplasma (c) do corpo celular. D: Terminações nervosas (estrela) constituídas por vesículas granulares (cabeça de seta), agranulares (seta) e neurofilamentos (\#) no interior do gânglio mioentérico. E: Gânglio mioenterico $(\mathrm{GM})$ envolvido externamente pela membrana basal (seta branca). F: Espaço periganglionar (EP) entre o gânglio mioentérico (GM) e a camada muscular (CM). G: Fibras colágenas (seta) no espaço periganglionar (EP). H - Fibroblastos (f) no espaço periganglionar (EP) 

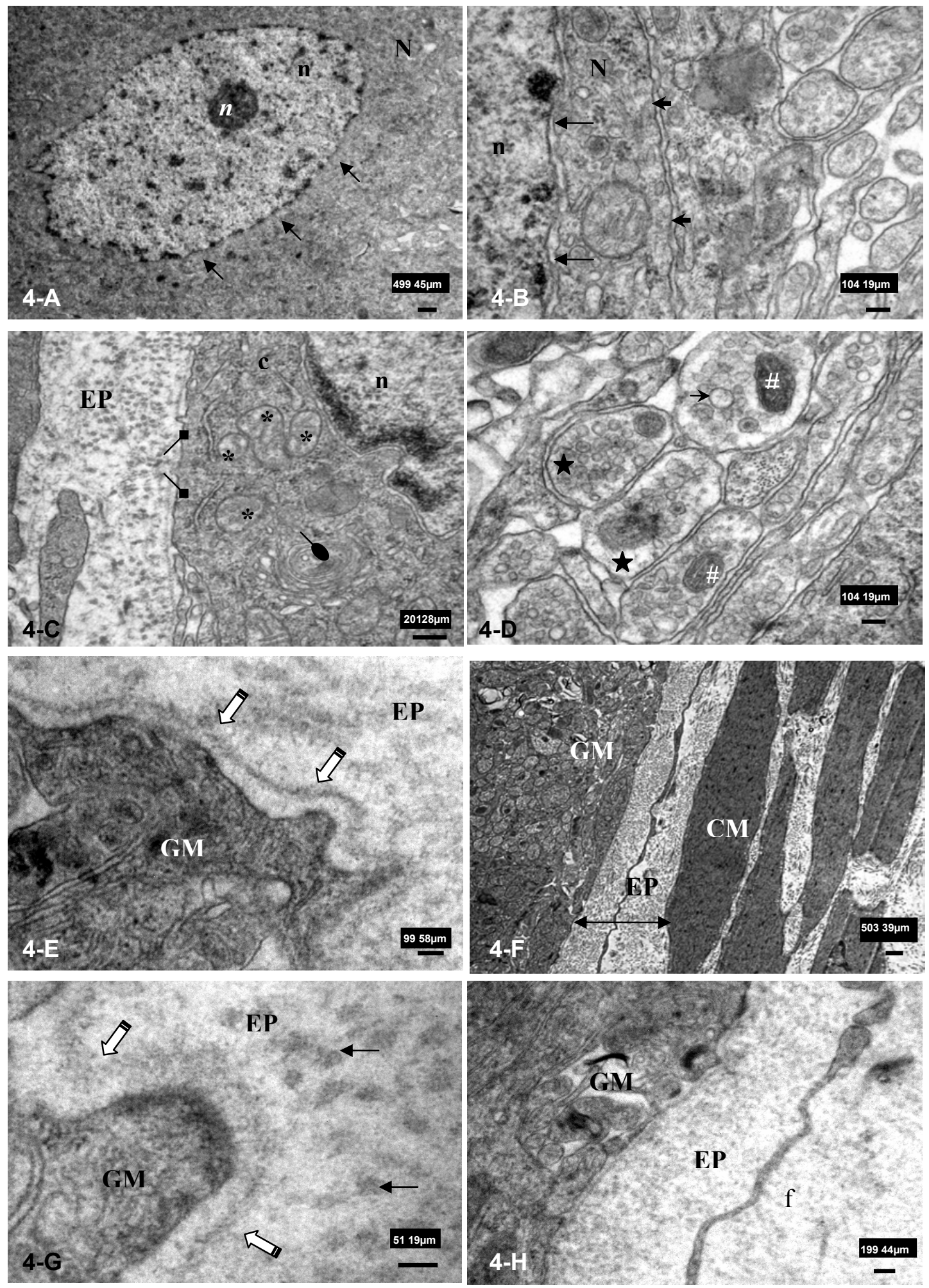
Figura $5(\mathrm{~A}-\mathrm{H})$ - Ultra-estrutura dos gânglios mioentéricos do colo de ratos de meia idade sedentários (Grupo B) $(A-H)$. A: Núcleo do neurônio (n), delimitado por sua respectiva membrana nuclear (seta), apresentando um formato arredondado. Constituído por um proeminente nucléolo $(n)$ e cromatina. B: Neurônio delimitado por uma integra membrana citoplasmática (cabeça de seta) e seu núcleo por uma correspondente membrana nuclear (seta). C: Organelas como retículo endoplasmático rugoso (cabeça de seta quadrada) e complexo de Golgi (cabeça de seta redonda) no citoplasma do corpo celular. D: Terminações nervosas (estrela) constituídas por vesículas granulares (seta) no interior do gânglio mioentérico. E: Gânglio mioentérico (GM) envolvido externamente pela membrana basal (seta branca). F: Espaço periganglionar (EP) entre o gânglio mioentérico (GM) e a camada muscular (CM). G: Fibras colágenas (seta) no espaço periganglionar. HFibroblastos ( $f$ ) no espaço periganglionar 

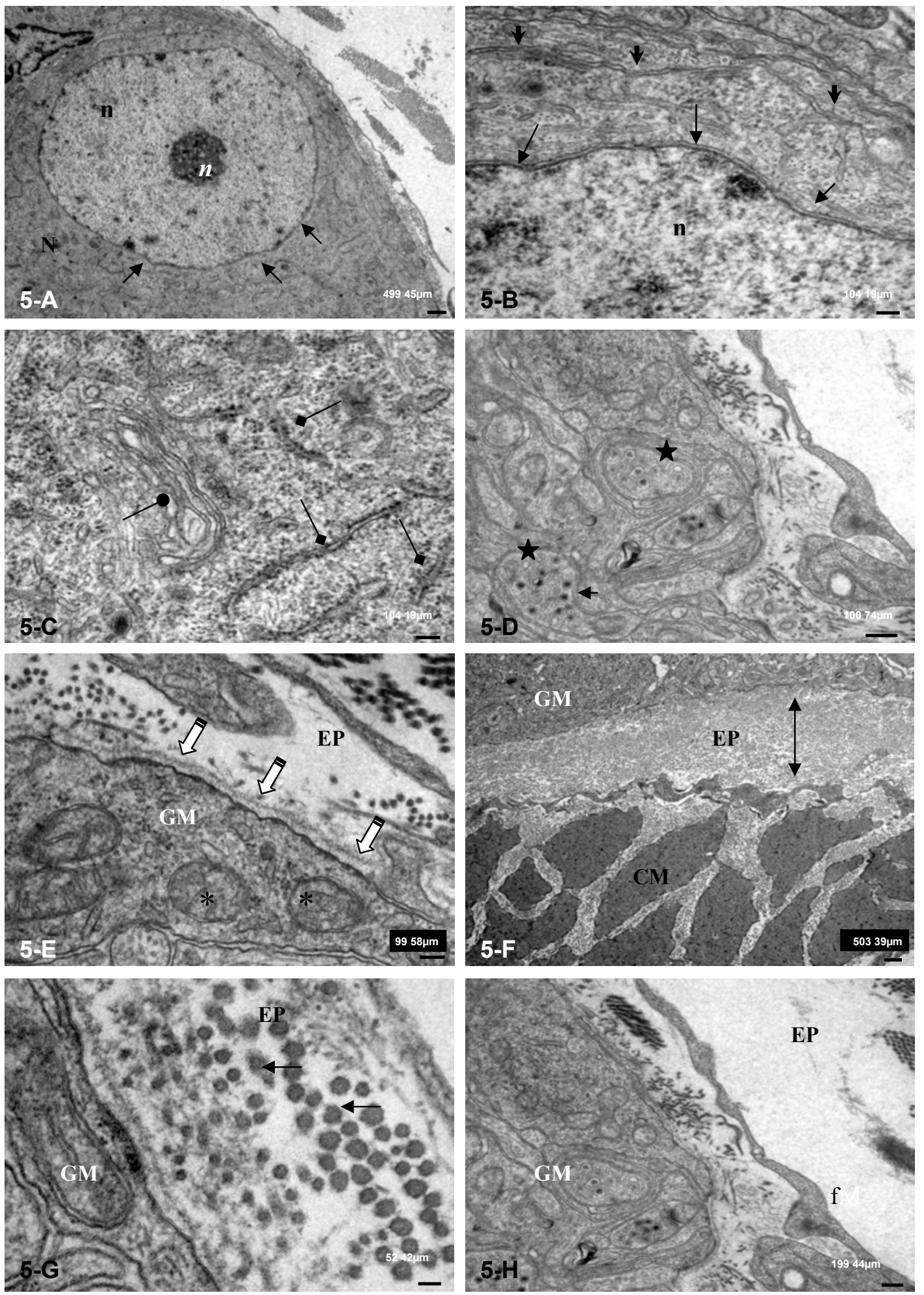
Figura $6(\mathrm{~A}-\mathrm{H})$ - Ultra-estrutura dos gânglios mioentéricos do colo de ratos de meia idade submetidos à atividade física (Grupo C). A: Núcleo do neurônio (n), delimitado por sua respectiva membrana nuclear (seta), apresentando um formato redondo. B: Núcleo do neurônio (n) delimitado por uma integra membrana nuclear (seta). C: Organelas como retículo endoplasmático rugoso (cabeça de seta quadrada) e complexo de Golgi (cabeça de seta redonda) no citoplasma do corpo celular (c). D: Terminações nervosas (estrela) constituídas por vesículas granulares (cabeça de seta), agranulares (seta), e neurofilamentos (\#) no interior do gânglio mioentérico (GM). E: Gânglio mioentérico (GM) envolvido externamente pela membrana basal (seta branca). F: Espaço periganglionar (EP) entre o gânglio mioentérico (GM) e a camada muscular (CM). G: Fibras colágenas (seta) no espaço periganglionar. $\mathrm{H}$ - Fibroblastos (f) no espaço periganglionar (EP). 

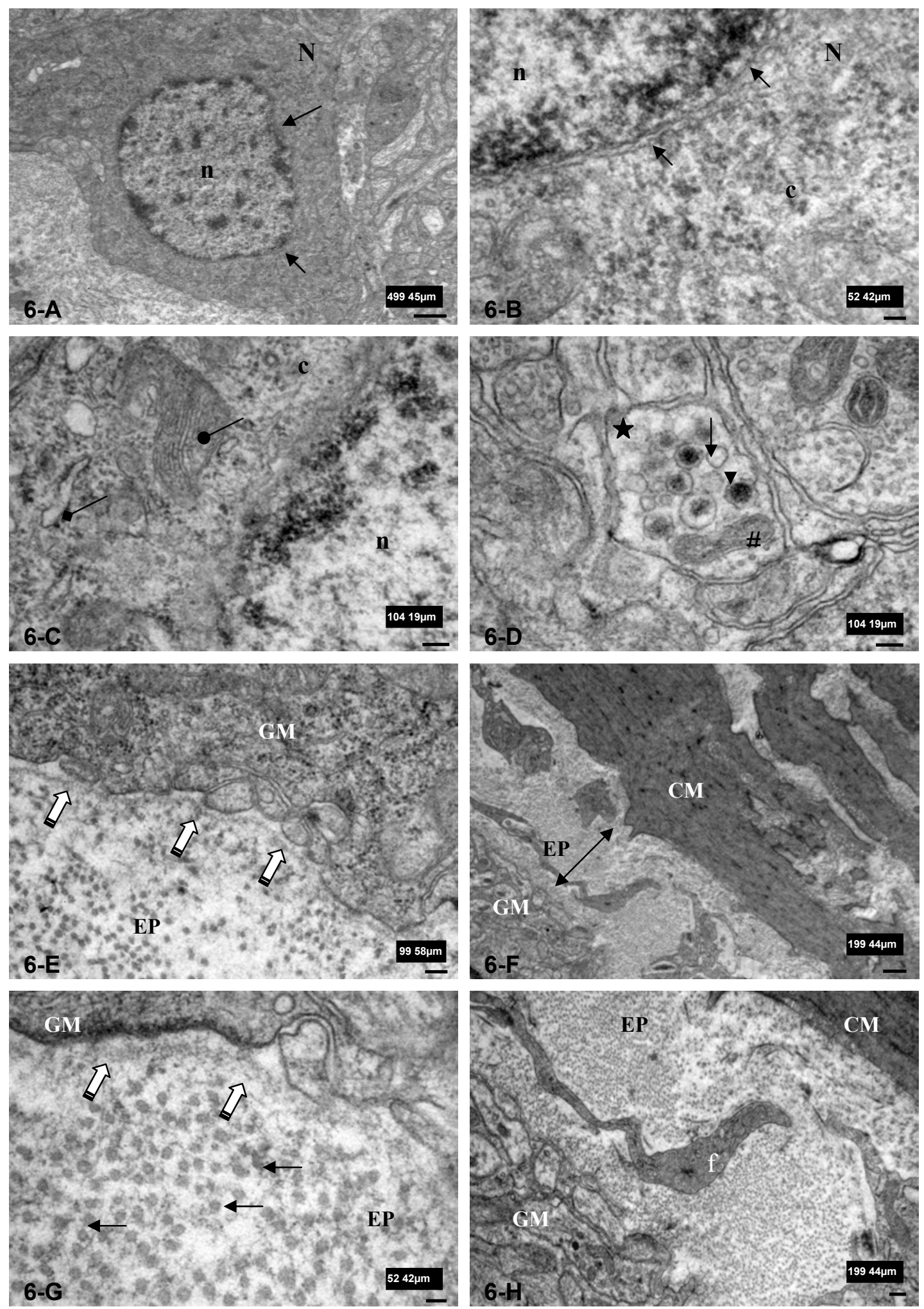


\subsection{ESTUDO QUANTITATIVO}

Os resultados referentes ao estudo quantitativo (densidade neuronal e estimativa do número total de neurônios) do plexo mioentérico do colo de ratos referentes às técnicas histoquímicas de NADH- e NADPH-diaforase estão representados sistematicamente na tabela 3.

\subsubsection{Densidade Neuronal}

A densidade neuronal para a técnica histoquímica de $\mathrm{NADH}$-diaforase no colo dos animais do grupo A variou de 238 a 306 neurônios/ mm² (média 276; desvio padrão 29,5; coeficiente de variação $10,7 \%$ ), sendo encontrado na porção ascendente do colo em média 286 neurônios $/ \mathrm{mm}^{2}$ e na porção descendente 267 neurônios $/ \mathrm{mm}^{2}$. No grupo B variou de 181,7 a 285,7 neurônios $/ \mathrm{mm}^{2}$ (média 228,7; desvio padrão 51,5; coeficiente de variação $22,5 \%$ ), sendo encontrado na porção ascendente do colo em média 227,7 neurônios $/ \mathrm{mm}^{2}$ e na porção descendente 230 neurônios $/ \mathrm{mm}^{2}$. No grupo C variou de 243,7 a 315,7 neurônios $/ \mathrm{mm}^{2}$ (média 280; desvio padrão 31,6 e coeficiente de variação $11 \%$ ), sendo encontrado na porção ascendente do colo em média 283 neurônios $/ \mathrm{mm}^{2}$ e na porção descendente 277 neurônios $/ \mathrm{mm}^{2}$ (Figura 7A). 
Os resultados referentes à densidade neuronal dos neurônios NADH-diaforase reativos não diferiram significativamente $(P<0,05)$ quando comparados os grupo entre si. Ainda, nenhuma diferença significativa $(P>0,05)$ foi encontrada entre as porções ascendente e descendente do colo (Tabela 4).

A densidade neuronal para a técnica histoquímica de NADPH-diaforase no colo dos animais do grupo A variou de 40 a 53 neurônios $/ \mathrm{mm}^{2}$ (média 48; desvio padrão 5; coeficiente de variação $11,7 \%$ ), sendo encontrado na porção ascendente do colo em média 45 neurônios $/ \mathrm{mm}^{2}$ e na porção descendente 50 neurônios $/ \mathrm{mm}^{2}$. No grupo B variou de 26 a 36 neurônios $/ \mathrm{mm}^{2}$ (média 33; desvio padrão 4; coeficiente de variação $12 \%$ ), sendo encontrado na porção ascendente do colo em média 33 neurônios $/ \mathrm{mm}^{2}$ e na porção descendente 33 neurônios $/ \mathrm{mm}^{2}$. No grupo C variou de 25 a 31 neurônios $/ \mathrm{mm}^{2}$ (média 27; desvio padrão 2,5 e coeficiente de variação $9 \%$ ), sendo encontrado na porção ascendente do colo em média 26 neurônios $/ \mathrm{mm}^{2}$ e na porção descendente 28 neurônios/mm² (Figura 7B).

Os resultados referentes à densidade neuronal dos neurônios NADPH-diaforase reativos demonstraram diferenças significativas $(P<0,05)$ quando comparado o grupo $A$ aos demais grupos (B e C). No entanto, o grupo B e C não diferiram entre si $(P>0,05)$. Ainda, nenhuma diferença significativa $(P>0,05)$ foi encontrada entre as porções ascendente e descendente do colo (Tabela 4). 


\subsubsection{Estimativa do Número Total de Neurônios}

Para estimar o número total de neurônios no colo de ratos, foi necessário o conhecimento da densidade neuronal, descrita anteriormente, e da área colônica, sendo descrita a seguir. O produto entre estas duas variáveis forneceu o número total de neurônios.

A área colônica dos animais do grupo A variou de 3.374 a 4.475 mm² (média $3.861 \mathrm{~mm}^{2}$; desvio padrão 448; coeficiente de variação $11 \%$ ). No grupo B variou de 3.259 a $4.371 \mathrm{~mm}^{2}$ (média $3.872 \mathrm{~mm}^{2}$; desvio padrão 366; coeficiente de variação 9\%). No grupo C variou de 2.969 a $4.702 \mathrm{~mm}^{2}$ (média $3.771 \mathrm{~mm}^{2}$; desvio padrão 487; coeficiente de variação 13\%) (Tabela 3)

A área colônica não diferiu significativamente $(P>0,05)$ entre os grupos estudados (Tabela 4)

A estimativa do número total de neurônios para a técnica histoquímica de NADHdiaforase no colo dos animais do grupo A variou de 819.416 a 1.291.277,7 (média 993.349; desvio padrão 183.872; coeficiente de variação $18,5 \%$ ). No grupo B variou de 736.952 a 1.236 .499 neurônios (média 889.887; desvio padrão 236.221; coeficiente de variação 26,5\%). No grupo C variou de 774.343 a 1.310 .764 neurônios (média 999.808; desvio padrão 213.111 e coeficiente de variação 21\%) (Figura 7C).

Os resultados referentes à estimativa do número total de neurônios NADHdiaforase reativos não diferiram significativamente $(P>0,05)$ entre os grupos $(A, B$ e $C)$. 
A estimativa do número total de neurônios para a técnica histoquímica de NADPH-diaforase no colo dos animais do grupo A variou de 144.117 a 237.775 (média 200.371; desvio padrão 38.986; coeficiente de variação 19\%). No grupo B variou de 105.366 a 154.674 (média 128.044; desvio padrão 17.791; coeficiente de variação 14\%). No grupo C variou de 90.587 a 131.698 (média 109.954; desvio padrão 19.017 e coeficiente de variação 17\%) (Figura 7D).

Os resultados referentes à estimativa do número total de neurônios NADPHdiaforase reativos foram diferentes significativamente $(P<0,05)$ quando comparado o grupo $A$ aos demais grupos (B e C). No entanto, nenhuma diferença significativa $(P>0,05)$ foi encontrada quando comparado o grupo $B$ ao $C$. 
Tabela 3 - Valores da densidade neuronal, área colônica e da estimativa do número total dos neurônios NADH- e NADPH-diaforase reativos do colo dos animais dos grupos A (ratos adultos), B (ratos de meia-idade sedentários) e C (ratos de meia idade submetidos a atividade física)

\begin{tabular}{|c|c|c|c|c|c|c|}
\hline & \multicolumn{2}{|c|}{$\begin{array}{c}\text { DENSIDADE } \\
\text { (neurônios/mm²) }\end{array}$} & \multicolumn{2}{|c|}{$\begin{array}{l}\text { ÁREA COLÔNICA } \\
\left(\mathrm{mm}^{2}\right)\end{array}$} & \multicolumn{2}{|c|}{$\begin{array}{l}\text { NÚMERO TOTAL DE } \\
\text { NEURÔNIOS }\end{array}$} \\
\hline & NADH & NADPH & NADH & NADPH & NADH & NADPH \\
\hline Grupo A & $\begin{array}{l}258,7 \\
306,0 \\
305,0 \\
273,7 \\
238,0\end{array}$ & $\begin{array}{l}53 \\
40 \\
48 \\
45 \\
53\end{array}$ & $\begin{array}{l}3.407,0 \\
4.217,0 \\
3.374,0 \\
3.450,7 \\
3.439,0\end{array}$ & $\begin{array}{l}4.475,0 \\
3.622,0 \\
4.061,0 \\
4.104,0 \\
4.461,0\end{array}$ & $\begin{array}{c}881.593,0 \\
1.291 .277,7 \\
1.029 .991,0 \\
944.468,0 \\
819.416,0\end{array}$ & $\begin{array}{c}236.483,0 \\
144.177,0 \\
197,0 \\
186.574,0 \\
237.775,0\end{array}$ \\
\hline Média & $\begin{array}{c}276 \\
286 C A^{*} \\
267 C D^{*}\end{array}$ & $\begin{array}{c}48 \\
45 C A^{*} \\
50 C D^{*} \\
\end{array}$ & \multicolumn{2}{|c|}{$3861^{* *}$} & $993.349,0$ & $200.371,0$ \\
\hline Grupo B & $\begin{array}{l}188.7 \\
259,0 \\
181.7 \\
285.7\end{array}$ & $\begin{array}{l}36 \\
35 \\
34 \\
35 \\
26\end{array}$ & $\begin{array}{l}3.934,0 \\
3.259,0 \\
4.055,0 \\
4.327,0\end{array}$ & $\begin{array}{l}3.595,0 \\
4.371,0 \\
3.600,0 \\
3.685,0 \\
4.007,0\end{array}$ & $\begin{array}{l}742.465,0 \\
843.633,0 \\
736.952,0 \\
123.649,0\end{array}$ & $\begin{array}{l}128.935,0 \\
154.674,0 \\
121.741,0 \\
129.506,0 \\
105.366,0\end{array}$ \\
\hline Média & $\begin{array}{c}228,7 \\
227,7 C A^{*} \\
230,0 C D^{*}\end{array}$ & $\begin{array}{c}33 \\
33 C A^{*} \\
33 C D^{*}\end{array}$ & \multicolumn{2}{|c|}{$3872^{* *}$} & $889.887,0$ & $128.044,0$ \\
\hline Grupo C & $\begin{array}{l}260,7 \\
243,7 \\
310,0 \\
269,7 \\
315,7\end{array}$ & $\begin{array}{l}28 \\
31 \\
26 \\
26 \\
25\end{array}$ & $\begin{array}{l}2.969,0 \\
3417,7 \\
3.476,0 \\
3.713,0 \\
4.151,0\end{array}$ & $\begin{array}{l}4.702,0 \\
4.091,0 \\
3.406,0 \\
3.939,0 \\
3.842,0\end{array}$ & $\begin{array}{c}774.343,0 \\
832.968,0 \\
1.079 .166,0 \\
1.001800,0 \\
1.310 .764,0\end{array}$ & $\begin{array}{c}131.698,0 \\
128.502,0 \\
90.587,0 \\
103.718,0 \\
95.265,0\end{array}$ \\
\hline Média & $\begin{array}{c}280,0 \\
283 C A^{*} \\
277 C D^{*}\end{array}$ & $\begin{array}{c}27 \\
26 C A^{*} \\
28 C D^{*}\end{array}$ & \multicolumn{2}{|c|}{$3771^{* *}$} & $999.808,0$ & $109.954,0$ \\
\hline
\end{tabular}

${ }^{*} \mathrm{CA}=$ colo ascendente; $\mathrm{CD}=$ colo descendente

** Média colônica geral (média dos colos destinados as técnicas de NADH- e NADPH-diaforase) 


\section{DENSIDADE NEURONAL (neurônios/mm²)}

$\mathrm{NADH}$

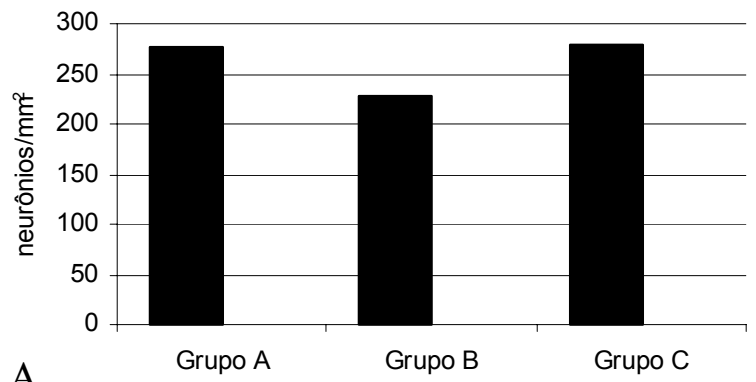

NADPH

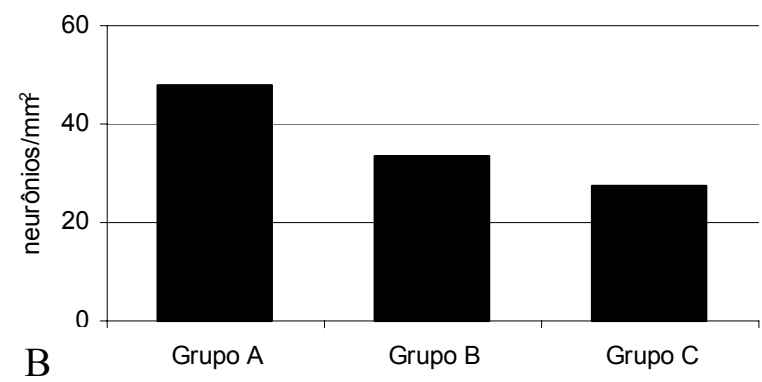

\section{ESTIMATIVA DO NÚMERO TOTAL DE NEURÔNIOS}

$\mathrm{NADH}$

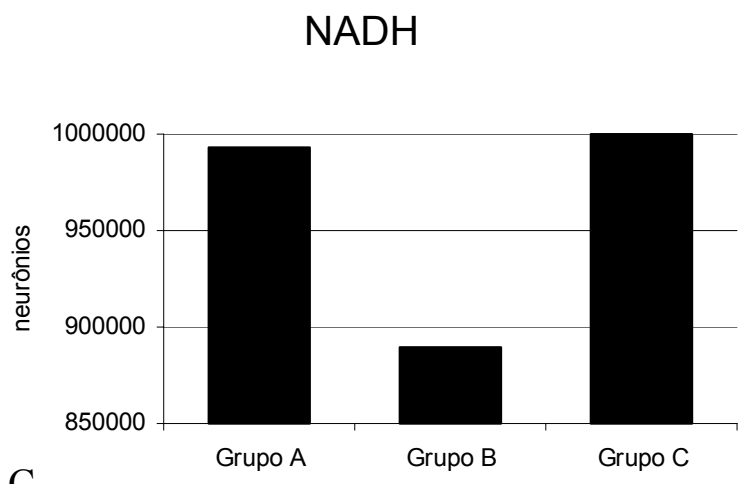

$\mathrm{C}$

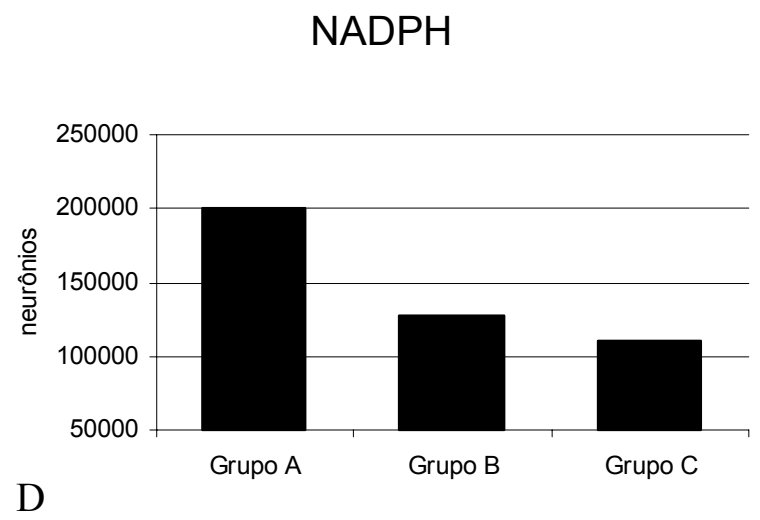

NADPH

Figura 7 (A-D) - Gráficos referentes ao estudo quantitativo (densidade neuronal e estimativa do número total de neurônios). (A): Média da densidade neuronal dos neurônios $\mathrm{NADH}$-diaforase reativos nos grupos $\mathrm{A}, \mathrm{B}$ e $\mathrm{C}$. (B): Média da densidade neuronal dos neurônios NADPH-diaforase reativos nos grupos A, B e C. (C): Média da estimativa do número total de neurônios $\mathrm{NADH}$-diaforase reativos nos grupos $\mathrm{A}, \mathrm{B}$ e C. (D): Média da estimativa do número total de neurônios NADPH-diaforase reativos nos grupos $A, B$ e $C$ 
Tabela 4 - Médias da densidade neuronal, da área colônica e da estimativa do número total de neurônios nos grupos $A$ (ratos adultos), $B$ (ratos de meia idade sedentários) e $\mathrm{C}$ (ratos de meia idade submetidos à atividade física) e sua significância estatística

\begin{tabular}{lcclcc}
\hline & \multicolumn{2}{c}{$\begin{array}{c}\text { DENSIDADE } \\
\text { NEURONAL }\end{array}$} & $\begin{array}{c}\text { ÁREA } \\
\text { COLÔNICA }\end{array}$ & \multicolumn{2}{c}{$\begin{array}{c}\text { NÚMERO TOTAL DE } \\
\text { NEURÔNIOS }\end{array}$} \\
& NADH & NADPH & & NADH & NADPH \\
\cline { 2 - 6 } & & & & & \\
Grupo A & $276 a^{*}$ & $48 a$ & $3861 a$ & $993.349 a$ & $200.371 a$ \\
Grupo B & $228,7 a$ & $33 b$ & $3872 a$ & $889.887 a$ & $128.044 b$ \\
Grupo C & $280 a$ & $27 b$ & $3771 a$ & $999.808 a$ & $109.954 b$ \\
\hline
\end{tabular}

* Médias seguidas por letras diferentes na mesma coluna diferem pelo método de Tukey $(P<0,05)$

\subsection{ESTUDO MORFOMÉTRICO}

Os resultados morfométricos (área dos perfis neuronais e espessura da camada muscular) estão descritos a seguir. 


\subsection{1 Área dos Perfis Neuronais}

A área do perfil neuronal para a técnica histoquímica de NADH-diaforase no colo dos animais do grupo A variou de 17 a $555 \mu \mathrm{m}^{2}$ (média $129 \mu \mathrm{m}^{2}$; desvio padrão 26,7; coeficiente de variação $20,7 \%$ ), sendo na porção ascendente do colo em média $130,7 \mu \mathrm{m}^{2}$ e na porção descendente $127,7 \mu \mathrm{m}^{2}$. No grupo B variou de 28 a $667 \mu \mathrm{m}^{2}$ (média $164 \mu \mathrm{m}^{2}$; desvio padrão 24,5; coeficiente de variação $15 \%$ ), sendo na porção ascendente do colo em média $175 \mu \mathrm{m}^{2}$ e na porção descendente $153 \mu \mathrm{m}^{2}$. No grupo C variou de 15 a $598 \mu \mathrm{m}^{2}$ (média 137; desvio padrão 18,7 e coeficiente de variação $13,7 \%)$, sendo encontrado na porção ascendente do colo em média $155 \mu m^{2}$ e na porção descendente $119 \mu \mathrm{m}^{2}$ (Figura 8A).

Não foi verificada diferença significativa $(P>0,05)$ na área dos neurônios NADHreativos entre os grupos $A, B$ e $C$ (Tabela 4). Ainda, nenhuma diferença significativa $(P>0,05)$ foi verificada entre as porções ascendente e descendente do colo.

No grupo A, 85\% dos neurônios apresentaram tamanho entre 1-200 $\mu \mathrm{m}^{2}$, sendo $43 \%$ destes entre $1-100 \mu m^{2}$ e $42 \%$ entre $100-200 \mu \mathrm{m}^{2}$. No grupo $B, 46 \%$ dos neurônios apresentaram tamanho entre 100-200 $\mu^{2}$. No grupo C, 43,2\% dos neurônios apresentaram tamanho entre $100-200 \mu \mathrm{m}^{2}$ (Figura 8B).

A área do perfil neuronal para a técnica histoquímica de NADPH-diaforase no colo dos animais do grupo A variou de 55 a $919 \mu \mathrm{m}^{2}$ (média 208,7 $\mu \mathrm{m}^{2}$; desvio padrão 33,7 ; coeficiente de variação $16 \%$ ), sendo na porção ascendente do colo em média 
$195 \mu \mathrm{m}^{2}$ e na porção descendente $222 \mu \mathrm{m}^{2}$. No grupo B variou de 23 a $724 \mu \mathrm{m}^{2}$ (média $161 \mu \mathrm{m}^{2}$; desvio padrão 46; coeficiente de variação $28,7 \%$ ), sendo na porção ascendente do colo em média $198 \mu \mathrm{m}^{2}$ e na porção descendente $125 \mu \mathrm{m}^{2}$. No grupo C variou de 20 a $967 \mu m^{2}$ (média 174; desvio padrão 78 e coeficiente de variação 44\%), sendo encontrado na porção ascendente do colo em média $151 \mu \mathrm{m}^{2}$ e na porção descendente $197 \mu \mathrm{m}^{2}$ (Figura $8 \mathrm{C}$ ).

Não foi verificada diferença significativa $(P>0,05)$ na área do perfil dos neurônios NADPH-reativos entre os grupos A, B e C (Tabela 6). Ainda, nenhuma diferença significativa $(P>0,05)$ foi verificada entre as porções ascendente e descendente do colo.

No grupo A, 52\% dos neurônios apresentaram tamanho entre $100-200 \mu m^{2}$. No grupo B, $42 \%$ dos neurônios apresentaram tamanho dentre $100-200 \mu m^{2}$. No grupo C, $41 \%$ dos neurônios apresentaram tamanho entre 1-100 $\mu^{2}$ (Figura 8D). 


\section{NADH}

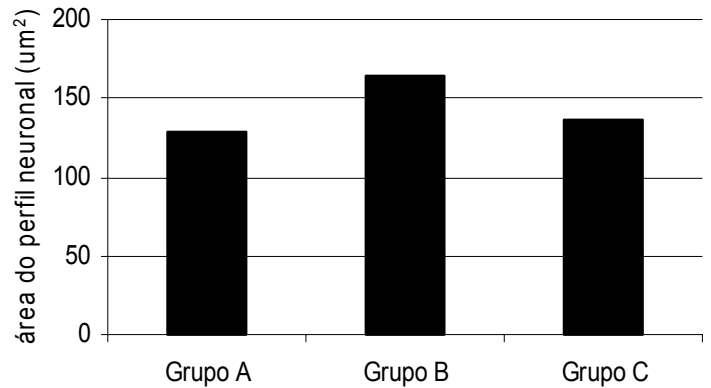

A

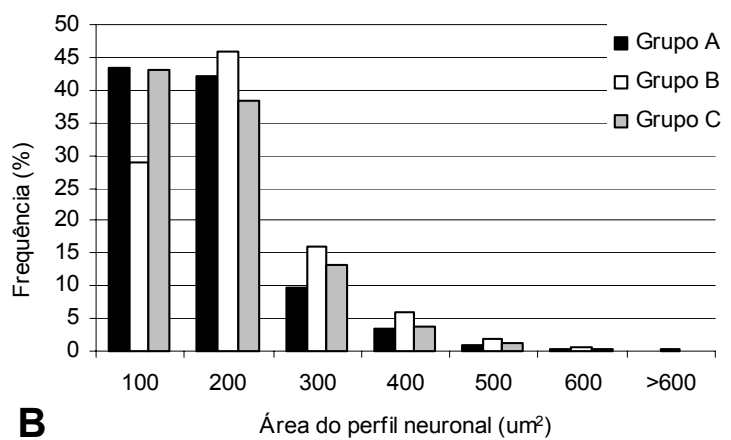

B

\section{NADP}
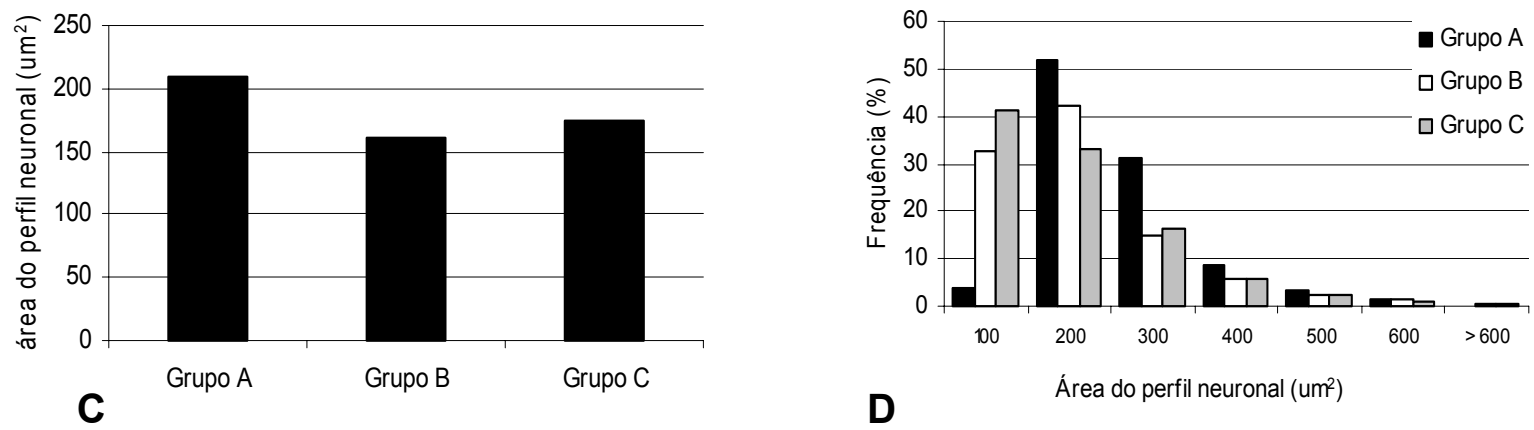

Figura 8 (A-D) - Gráficos referentes à área seccional dos neurônios. (A): Média da área seccional dos neurônios NADH-reativos nos grupos A, B e C. (B): Distribuição neuronal de acordo com os intervalos de classes de área dos neurônios NADH-reativos nos grupos A, B e C. (C): Média da área seccional dos neurônios NADPH-reativos nos grupos A, B e C. (D): Distribuição neuronal de acordo com os intervalos de classes de área dos neurônios $\mathrm{NADPH}$-reativos nos grupos A, B e C 


\subsubsection{Espessura da Camada Muscular}

A espessura da camada muscular (circular e longitudinal) no grupo A variou de 169 a $210 \mu \mathrm{m}^{2}$ (média $192 \mu \mathrm{m}^{2}$; desvio padrão 21; coeficiente de variação 12\%), sendo na porção ascendente do colo em média $201,7 \mu \mathrm{m}^{2}$ e na porção descendente $183 \mu \mathrm{m}^{2}$. No grupo B variou de 205 a 247,7 $\mu \mathrm{m}^{2}$ (média $225 \mu \mathrm{m}^{2}$; desvio padrão 19; coeficiente de variação $8 \%$ ), sendo na porção ascendente do colo em média $226 \mu m^{2}$ e na porção descendente 223,7 $\mu \mathrm{m}^{2}$. No grupo C variou de 140,7 a $245 \mu \mathrm{m}^{2}$ (média 205; desvio padrão 40 e coeficiente de variação 19), sendo encontrado na porção ascendente do colo em média $212 \mu \mathrm{m}^{2}$ e na porção descendente $197 \mu \mathrm{m}^{2}$ (Figura 9).

Não foi verificada diferença significativa $(P>0,05)$ na espessura da camada muscular entre os grupos $A, B, C$. Ainda, nenhuma diferença significativa $(P>0,05)$ foi verificada entre a porção ascendente e descendente do colo (Tabela 6). 


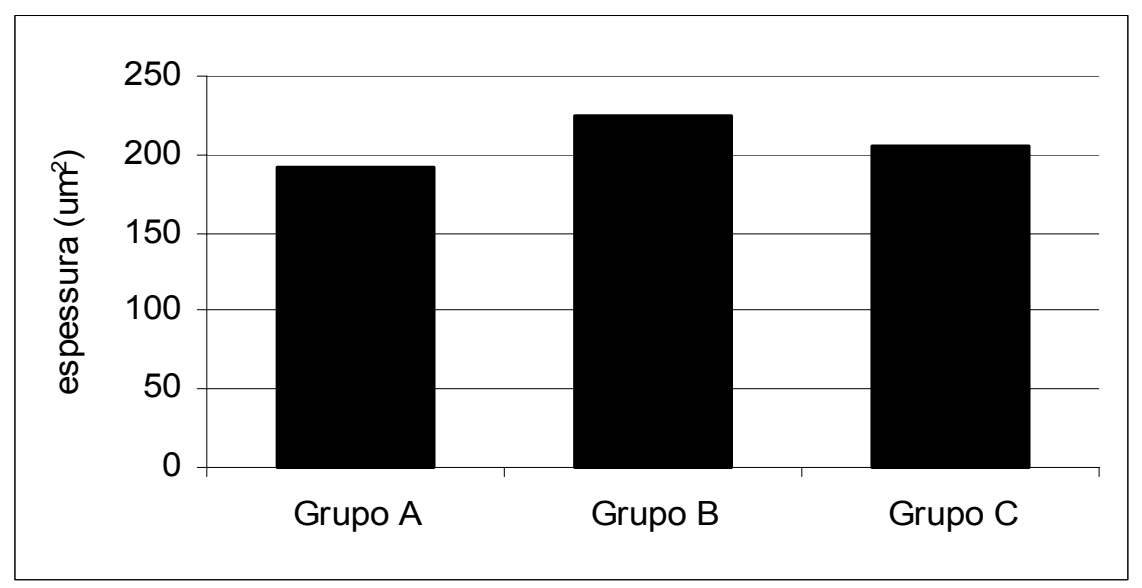

Figura 9 - Média da espessura da camada muscular (circular e longitudinal) nos grupos A (ratos adultos), B (ratos de meia idade sedentários) e C (ratos de meia idade submetidos à atividade física)

Tabela 6 - Médias da área dos perfis neuronais dos neurônios NADH- e NADPHdiaforase positivos e da espessura da camada muscular nos grupos $A$ (ratos adultos), B (ratos de meia idade sedentários) e C (ratos de meia idade submetidos à atividade física) e sua significância estatística.

\begin{tabular}{|c|c|c|c|}
\hline & \multicolumn{2}{|c|}{$\begin{array}{l}\text { ÁREA DO PERFIL NEURONAL } \\
\left(\mu^{2}\right)\end{array}$} & \multirow[t]{2}{*}{$\begin{array}{l}\text { ESPESSURA DA } \\
\text { CAMADA MUSCULAR }\end{array}$} \\
\hline & $\mathrm{NADH}$ & NADPH & \\
\hline Grupo A & $129 a$ & $208,7 a$ & $192 a$ \\
\hline Grupo B & $164 a$ & $161 a$ & $225 a$ \\
\hline Grupo C & $137 a$ & $174 a$ & $205 a$ \\
\hline
\end{tabular}

* Média seguidas por letras diferentes na mesma coluna diferem pelo método de Tukey $(P<0,05)$. 


\section{DISCUSSÃO}

Este capítulo visa discutir os seguintes itens: atividade física, peso corpóreo, anatomia microscópica do plexo mioentérico, aspectos ultra-estruturais, estudo morfométrico, espessura da camada muscular. Ainda apresenta algumas considerações finais.

\subsection{ATIVIDADE FÍSICA}

A instituição de um programa de treinamento físico é responsável por uma melhora significativa na performance dos animais. Tal afirmação baseia-se nos resultados obtidos nesta investigação científica, onde os animais (ratos) submetidos a um programa diário de treinamento, com intensidade sub-máxima (60\%) (grupo C), apresentaram melhora significativa $(P<0,05)$ no desempenho quando comparado com animais (ratos) sedentários (grupo B). O desempenho observado nos animais do grupo C seguiu três diferentes fases: uma ascensão, um platô e posterior declínio. Contudo, mesmo em fase de declínio, o desempenho do grupo $C$ foi incomparável com os animais do grupo B. O declínio no desempenho nos animais do grupo $\mathrm{C}$, de acordo com Mcardle (1998), associa-se ao envelhecimento, onde é natural uma diminuição da performance. 


\subsection{PESO CORPÓREO}

Os animais do grupo B (ratos de meia idade sedentário), assim como os animais do grupo C (ratos de meia idade submetidos à atividade física), ganharam progressivamente peso durante o período experimental, com exceção do ultimo mês de análise, onde ambos os grupos tiveram uma redução no peso comparado com as pesagens anteriores. Todavia, do primeiro mês de experimento para o segundo, enquanto os animais do grupo C aumentaram em apenas 3\% o peso corpóreo, os animais do grupo B aumentaram em 7,5\%. A partir do segundo mês, ambos os grupos tiveram, aproximadamente, a mesma porcentagem de ganho de peso, entre 3-4\%. Contudo, a partir da quinta pesagem, tanto os animais do grupo $\mathrm{B}$, quanto os animais do grupo C, começaram a ganhar uma porcentagem menor de peso, em comparação com os outros meses, progredindo para uma perda de peso corpóreo verificada na sétima pesagem.

Os resultados obtidos nesta investigação assemelham-se as descrições encontradas na literatura onde, na espécie humana, é relatado que após os 35 anos de idade, tanto homens como mulheres, que não participam de um programa diário de atividade física, tendem a ganhar mais gordura corporal até a quinta ou sexta década de vida. Após os sessenta anos de idade, o peso corporal total é reduzido apesar de um maior nível de gordura corporal. Entretanto, os indivíduos que participam de um programa de treinamento, aumentam o seu peso corporal magro e reduzem a gordura corporal. Porém, dependendo do grau de envelhecimento, ocorre perda de peso dado o 
declínio geral na função neuromuscular e a deterioração na capacidade celular de realizar a síntese protéica (MCARDLE, 1998).

\subsection{ANATOMIA MICROSCÓPICA DO PLEXO MIOENTÉRICO}

As características microestruturais do plexo mioentérico entre os grupos A (ratos adultos), B (ratos de meia idade sedentário) e C (ratos de meia idade submetidos à atividade física) não diferiram entre si e nem dos relatos encontrados na literatura. Assim, a localização do plexo mioentérico, a disposição dos neurônios no interior de gânglios e eventualmente no trajeto das fibras nervosas e a presença de fibras nervosas que se interconectam formando os plexos primário, secundário e terciário já foram amplamente descritos (FURNESS; COSTA, 1987; GABELLA, 1979, 1995; SANTER; BAKER, 1993; SCHEMANN; NEUNLIST, 2004).

Mudanças morfológicas no corpo neuronal (pericário), nos gânglios e no arranjo do plexo não foram observadas entre os grupos por meio da microscopia de luz utilizando as técnicas histoquímicas de NADH- e NADPH- diaforase. Entretanto, alterações na densidade de neurônios e no tamanho do perfil neuronal entre os grupos foram verificadas.

Quanto ao arranjo, o plexo mioentérico do colo de ratos apresentou diferenças entre suas porções (ascendente e descendente). Na porção ascendente do colo, foi verificada uma distribuição heterogênea, tendo a região mesentérica um denso plexo e 
na região antimesentérica um plexo não tão denso, constituído por gânglios mais espaçados e fibras nervosas não tão espessas. Um aspecto heterogêneo do plexo mioentérico também foi verificado por Gabella $(1979,1990)$ em cobaias, onde o plexo era constituído por pequenos gânglios na região abaixo da prega do peritônio, gânglios grandes e muito próximos em regiões adjacentes a prega peritonial e gânglios mais afastados na região antiperitonial.

Já a porção descendente do colo de ratos apresentou distribuição regular do plexo mioentérico por toda a circunferência intestinal, descrita também por Araújo et al. (2003). Em espécies onívoras e carnívoras, como o cão, gato, macaco e marsupiais (American opossum e Australian brush-tailed possum), foi relatada a presença de uma região que não é encontrada em roedores como rato, coelho e cobaia. Esta região é representada pela porção mais distal do colo descendente, e é verificada por um plexo de disposição irregular, com muitas fibras nervosas de vários tamanhos com poucos e pequenos gânglios. As outras regiões do colo descendente apresentam um grande plexo estrelado, com disposição regular conectados por fibras nervosas, sendo comum nas espécies onívoras e carnívoras (CHRISTENSEN et al.,1984). 


\subsection{ANATOMIA ULTRA-ESTRUTURAL}

Nenhuma alteração significativa na ultra-estrutura dos neurônios entéricos entre os grupos (A, B e C) foi verificada. As possíveis alterações associadas ao envelhecimento, como sinais de degeneração, não foram evidenciadas. Tal fato pode estar vinculado aos relatos de Gabella (1989), onde este afirma que os sinais de degeneração não acometem todos os neurônios no interior dos gânglios. Ainda, a não evidencia de sinais de degeneração pode estar associado à fase de desenvolvimento destes animais. Talvez aos doze meses de idade as alterações do envelhecimento não tenham sido iniciadas. Entretanto, uma maior síntese protéica é sugerida nos animais do grupo B (ratos de meia idade sedentários), devido à presença de uma maior quantidade de heterocromatina no núcleo. Tal fato pode estar vinculado a uma maior produção de determinados tipos de neurotransmissores dada a uma possível diminuição na produção destes por outros neurônios presentes no gânglio, diminuição esta possivelmente associada às etapas iniciais do envelhecimento.

Diferenças também não foram evidenciadas nos neurônios dos animais (ratos) submetidos á atividade física (grupo C). No entanto, a cromatina destes neurônios apresentava-se mais dispersa, semelhantemente a dos animais do grupo A. Provavelmente, os neurônios do grupo A e C não necessitam de uma intensa atividade protéica.

Externamente ao gânglio, algumas alterações foram evidenciadas. Uma maior quantidade de colágeno no espaço periganglionar nos animais do grupo B quando 
comparados aos demais grupos. Esta afirmação condiz aos relatos de Gomes et al. (1997), onde um aumento de colágeno e também elastina foi verificado com o envelhecimento. A não ocorrência de tal fato nos animais do grupo C sugere o efeito benéfico da atividade física, em manter a estrutura do gânglio semelhantemente a dos animais do grupo $A$, ratos adultos.

\subsection{ESTUDO QUANTITATIVO E MORFOMÉTRICO}

As discussões referentes ao estudo quantitativo e morfométrico foram divididas em quatros subitens: considerações metodológicas, neurônios NADH-diaforase reativos, neurônios NADPH-diaforase reativos e hipóteses referentes à atividade física.

\subsubsection{Considerações Metodológicas}

Os estudos quantitativo e morfométrico dos neurônios foram conduzidos por meio de preparados de membrana do colo, ao invés de secções histológicas. De acordo com Konigsmark (1970), a utilização de preparados de membrana elimina problemas de processamento (fixação, inclusão e secção), que poderiam afetar aparentemente a densidade neuronal (KARAOSMANOGLU et al., 1996). Ainda, há relatos na literatura científica que a utilização de preparados de membrana permite uma eficiente 
comparação de dados referentes à densidade neuronal, como também torna possível uma rápida amostragem do grande número de gânglios em apenas um único preparado de tecido (SAFFREY, 2004). Contudo, esta última afirmação deve ser considerada, uma vez que um determinado órgão pode apresentar variações regionais no número de neurônios. Estas variações, quando estudadas em apenas um preparado de membrana, podem refletir erroneamente mudanças patológicas ou mesmo alterações decorrentes do envelhecimento (PHILLIPS; POWLEY, 2001). Por esta razão, a presente pesquisa utilizou para cada animal quatro preparados de membrana coletados de maneira sistemática e aleatória por todo o comprimento do colo.

O crescimento dos segmentos do trato gastrointestinal (TGI), verificado nas etapas do desenvolvimento, resulta em uma redução aparente na densidade neuronal do plexo mioentérico (GABELLA, 1971, 1989). Desta forma, é descrito na literatura a utilização de um fator de correção para evitar erros na interpretação de dados referentes à densidade neuronal, onde este fator é derivado da razão entre a área do intestino de um animal jovem pela área de um animal senil (GABELLA, 1971, 1989; JOHNSON et al., 1998; PHILLIPS; KIEFFER; POWLEY, 2003; PHILLIPS; POWLEY, 2001). Entretanto, este fator de correção não foi utilizado nos resultados desta pesquisa, uma vez que não houve diferença significativa $(P>0,05)$ na área colônica nos diferentes grupos estudados (grupos A, B e C), permitindo uma comparação direta entre os resultados.

Além da possível diluição neuronal que acomete os animais de diferentes idades quando não utilizado o fator de correção, uma diminuição na densidade neuronal devido a um aumento no perfil neuronal pode ocorrer durante as etapas de processamento, 
uma vez que a distensão do órgão, com solução específica, é uma etapa usual para a elaboração do preparado de membrana (GABELLA, 1971). Ainda, durante a microdissecção pode ocorrer alterações na área, podendo levar a alterações sobre a real área de análise, originando uma supra-estimação ou subestimação dos resultados (SOUZA et al., 1993). Neste trabalho, procurou-se eliminar estas influências, através de correções apropriadas.

A marcação neuronal realizada por meio das técnicas histoquímicas de NADHdiaforase e NADPH-diaforase permitiu a obtenção de dados relevantes entre os grupos estudados. Embora a técnica de NADH-diaforase não evidencie em 100\% os neurônios, ela fornece um bom parâmetro de comparação entre os grupos estudados, por corar a grande maioria dos neurônios (YOUNG et al., 1993). Ainda, devido à reação histoquímica ser principalmente localizada na mitocôndria, e esta organela ser responsável pelo funcionamento energético, é possível verificar por meio da técnica de NADH-diaforase apenas os neurônios metabolicamente ativos.

Já a técnica histoquímica de NADPH-diaforase apresenta a distribuição idêntica da realizada por técnicas imunohistoquímicas para a detecção da enzima óxido nítrico sintase neuronal (BELAI; COOPER; BURNSTOCK, 1995; FURNESS et al., 1994), permitindo uma acurada estimativa da subpopulação de neurônios que sintetizam NO, neurotransmissor este responsável pelo relaxamento da musculatura lisa intestinal (SANDERS; WARD, 1992). 


\subsubsection{Neurônios NADH-Diaforase Reativos}

A perda de neurônios entéricos com o processo de envelhecimento é amplamente relatada, sendo esta perda muita extensa quando comparada com outras regiões do sistema nervoso (FINCH, 2003). No entanto, a diminuição neuronal pode relacionar-se com uma eliminação natural de neurônios, sendo vinculada ao processo natural do desenvolvimento (GABELLA, 1989) ou com uma deterioração neuronal devido ao envelhecimento, uma vez que eventualmente resulta em declínio funcional do órgão (PHILLIPS; POWLEY, 2001). Assim, como as demais porções do TGI, é descrito na literatura que o colo, porção do intestino grosso, apresenta uma significativa perda neuronal com o envelhecimento e, com exceção dos relatos de Takahashi et al. (2000) para o colo médio de ratos, é descrita uma diminuição de até $64 \%$ da população neuronal (SANTER; BAKER,1988).

A perda de neurônios mioentéricos colônicos pôde ser verificada por Santer e Baker (1988) quando compararam ratos de seis meses a ratos de 24 meses de idade, por El-Salhy, Sandström e Holmlund (1999) quando comparando camundongos de três meses com animais de 12 e 24 meses, por Phillips e Powley (2001) entre ratos de três a 27 meses de idade e por Phillips, Kieffer e Powley (2004) quando compararam ratos de 5-6 meses com ratos de 26 meses. Os resultados desta investigação científica também demonstram uma diminuição neuronal, embora não significativa $(P>0,05)$, com o envellhecimento (grupo A comparado ao grupo B). A perda neuronal não foi tão pronunciada, perfazendo apenas $17 \%$. Tal resultado sugere que a perda de neurônios 
pode ser gradativa e progressiva, sendo mais acentuada em ratos com idade mais avançada, uma vez que Hall (2002) constatou que as mudanças são mais pronunciadas em animais extremo velhos (ratos a partir de 28 meses de idade).

De acordo com dados da literatura, o exercício influencia a neurogênese em certas regiões do sistema nervoso central (hipocampo) (ARIDA et al., 2004a, b; BRAZEL; RAO, 2004; CHURCHILL et al., 2002; NEUPER et al., 1996). No entanto, no sistema nervoso entérico nenhum efeito da atividade física foi estudado anteriormente. De acordo com os nossos resultados, um programa de atividade física com carga submáxima (apenas $60 \%$ da capacidade máxima) e diário foi responsável por um ligeiro aumento (1\%) na densidade neuronal (grupo A comparado ao grupo C). Tal efeito pode ser vinculado a uma possível manutenção dos fatores neurotróficos, (WADE; COWEN, 2004), ou a uma maior resistência aos radicais livres, como verificado nas pesquisas que utilizaram modelos de restrição calórica (COWEN et al., 2000; JOHNSON et al., 1998), ou mesmo a uma diferenciação das células tronco neuronais encontradas no intestino (KRUGER et al., 2002) com a atividade física.

Da mesma forma, o tamanho dos perfis neuronais não demonstrou diferenças significativas entre si. No entanto, nos animais do grupo B (ratos de meia idade sedentário) os neurônios apresentaram um tamanho $27 \%$ maior do que os animais do grupo A (ratos adultos), podendo ser o início de uma hipertrofia compensatória em resposta ao inicio da perda neuronal, como também descrito por Phillips, Kieffer e Powley (2003). Já os animais do grupo C (ratos de meia idade submetidos à atividade física) não apresentaram diferenças marcantes, tendo um ligeiro aumento de $6 \%$ no tamanho dos neurônios em relação aos animais do grupo A. 
O histograma referente à área do perfil neuronal do colo entre os grupos estudados demonstrou uma extensa variação de tamanhos, tendo classes neuronais que atingiram até $700 \mu m^{2}$. A distribuição neuronal, verificada por meio do histograma, no grupo A assemelhou-se a do grupo C, onde grande maioria dos neurônios apresentou tamanhos incluídos no intervalo de classe $0-200 \mu \mathrm{m}^{2}$, sendo $85 \%$ no grupo A e $81,6 \%$ no grupo C. Já os animais do grupo B apresentaram uma menor porcentagem de neurônios neste intervalo (74\%), conseqüentemente, uma maior porcentagem nas demais classes. Tal fato reafirma a hipótese de hipertrofia neuronal compensatória à morte celular. De acordo com Gabella (1971), um aumento no território de inervação é acompanhado de um aumento no neuroplasma. Assim, devido morte celular, os neurônios sobreviventes aumentam de tamanho para suprir o mesmo território de inervação.

Nenhuma diferença significativa $(P>0,05)$ no tamanho dos neurônios NADHdiaforase reativos foi verificada entre as porções ascendente e descendente do colo. Diferentemente, Takahashi e Owyang (1998) referem que os neurônios da porção ascendente são maiores do que os neurônios da porção descendente.

Quanto à estimativa do número total de neurônios, nenhuma diferença significativa $(P>0,05)$ foi verificada entre os diferentes grupos (grupo $A, B$ e $C$ ), embora o número total de neurônios estimado para o grupo $\mathrm{B}$ tenha sido $10,5 \%$ inferior ao do grupo $\mathrm{A}$, as analises dos dados no contexto unicamente estatístico corroboram os resultados obtidos para a densidade neuronal. 


\subsubsection{Neurônios NADPH-Diaforase Reativos}

Os diferentes fenótipos do sistema nervoso entérico no rato, assim como nas demais espécies animais, não devem ser igualmente susceptíveis ou protegidos do processo de neurodegeneração que ocorre com o envelhecimento (WADE, 2002), sendo a perda dos neurônios entéricos um processo seletivo. De acordo com Johnson et al. (1998), Phillips, Kieffer e Powley (2003) e Wade e Cowen (2004), a população de neurônios colinérgicos é mais vulnerável do que a de neurônios nitrérgicos. Segundo Wade e Cowen (2004), os neurônios nitrérgicos são protegidos talvez como uma conseqüência do uso do radical livre NO como um neurotransmissor.

Os dados referentes à expressão de NO no plexo mioentérico do colo são conflitantes. Phillips, Kieffer e Powley (2003) não verificaram diminuição na densidade da subpopulação neuronal que expressa NO no intestino grosso (colo e reto) quando comparado ratos jovens (3 meses) com ratos velhos (24 meses). Já Belai, Cooper e Burnstock (1995) verificaram aumento na quantidade de neurônios que expressam NO por gânglio durante o envelhecimento, relatando que $76 \%$ dos neurônios expressam NO aos seis meses idade e $100 \%$ dos neurônios aos 26 meses de idade no colo proximal de ratos. Por outro lado, Takahashi et al. (2000) verificaram uma diminuição significativa no número de neurônios do colo médio que expressam NOS por gânglio quando comparados ratos jovens (4-8 meses) com ratos senis (22-28 meses). Da mesma forma, verificamos uma significativa perda neuronal (15\%) entre os animais do 
grupo A (ratos adultos) comparados com os animais do grupo B (ratos de meia idade sedentários).

O tamanho dos perfis neuronais dos grupos $A$ e B não diferiu significativamente. No entanto, nos animais do grupo A, os neurônios apresentaram um tamanho $23 \%$ maior do que aqueles dos animais do grupo B. Este fato, relacionado a uma maior densidade neuronal, reflete um agrupamento maior de neurônios no grupo $A$ do que nos animais do grupo B. Já os neurônios do grupo B são mais esparsos e possivelmente estão em processo de degeneração (atrofia) uma vez que analisando o histograma deste dois grupos foi verificado que 32\% dos neurônios do grupo B apresentaram tamanhos que variam entre $0-100 \mu m^{2}$, enquanto que no grupo $A$ apenas $4 \%$ encontrava-se no referido intervalo de classe.

A densidade dos neurônios nitrérgicos também diminui significativamente $(P<0,05)$, com valores em torno de $43,7 \%$, entre os animais do grupo $C$ (ratos de meia idade submetidos a atividade física) quando comparada aos animais do grupo A (ratos adultos), sendo a diminuição mais pronunciada do que nos animais do grupo B (ratos de meia idade sedentários). Entretanto, quando verificado o tamanho do perfil neuronal, a diminuição deste foi de $17 \%$, menos pronunciada no grupo $\mathrm{C}$ do que nos animais do grupo B (23\%). A análise do histograma de distribuição dos neurônios dos grupos B e C segundo os intervalos de classes do tamanho neuronal foi similar, ambos os grupos apresentando $74 \%$ dos neurônios com tamanho que variou entre 0-200 $\mu \mathrm{m}^{2}$, entretanto, $41 \%$ dos neurônios no grupo $C$ apresentaram em tamanhos entre $0-100 \mu m^{2}$, talvez relacionado com a perda celular mais pronunciada. 
A estimativa do número total de neurônios NADPH-reativos, igualmente a técnica de NADH-diaforase, serviu para consolidar os dados referentes à densidade neuronal. Ainda, analisando as médias do número total de neurônios entre os grupo de estudados e entre as diferentes técnicas histoquimicas (NADH- e NADPH-diaforase), foi possível constatar que no animal adulto (grupo A) aproximadamente $20 \%$ da população de neurônios metabolicamente ativa é constituída por neurônios nitrérgicos. Nos animais de meia-idade sedentários (grupo B) é aproximadamente $14 \%$ e nos animais de meia idade submetidos à atividade física (grupo C) é de aproximadamente $11 \%$. Os dados obtidos diferem daqueles obtidos por Belai, Cooper e Burnstock (1995), onde no colo proximal de ratos de seis meses e de 26 meses de idade foi constatado, respectivamente, que $76 \%$ e $100 \%$ dos neurônios liberam NO.

\subsubsection{Hipóteses Referentes à Atividade Física}

Algumas especulações podem ser sugeridas aos resultados obtidos nesta investigação. É sabido que para um trânsito normal da ingesta no TGI os neurônios excitatórios devem estar equilibrados em quantidade com os neurônios inibitórios (LOMAX; FURNESS, 2000; MITOLO-CHIEPPA et al., 1998; PHILLIPS; KIEFFER; POWLEY; 2003). Contudo, é descrito um aumento no tempo do trânsito colônico com o envelhecimento relacionado ao desequilíbrio entre as populações neuronais excitatórias e inibitórias. De acordo com Phillips, Kieffer e Powley (2003), os efeitos do envelhecimento (diminuição neuronal) ocorrem exclusivamente na população 
colinérgica (neurônios excitatórios). Tal fato, associado à manutenção (PHILLIPS; KIEFFER; POWLEY, 2003) ou aumento (BELAI; COOPER; BURNOSTOCK, 1999) da população nitrérgica com o envelhecimento resulta no aumento do trânsito colônico, uma vez que o relaxamento da camada circular é mantido e o tônus da camada longitudinal diminuído.

Entretanto, os resultados desta investigação científica diferem dos resultados descritos anteriormente. Embora tenha se mantido a população de neurônios metabolicamente ativos com o envelhecimento em ratos submetidos à atividade física (grupo C), a população de neurônios nitrérgicos diminuiu significativamente nestes animais, sendo mais acentuada do que nos animais sedentários (grupo B). Assim, não é possível relatar os efeitos da atividade física diretamente na motilidade colonica, uma vez que outras populações de neurônios inibitórios podem suprir a diminuição acentuada do neurotransmissor inibitório (óxido nítrico). Contudo, o benefício da atividade física nos neurônios entéricos pode estar intimamente relacionado à manutenção de neurônios metabolicamente ativos do colo, uma vez que a densidade dos neurônios evidenciados pela NADH-diaforase que inclui outros neurônios inibitórios, sem serem os nitrérgicos, não diminui significativamente em relação ao grupo A. 


\subsection{ESPESSURA DA CAMADA MUSCULAR}

De acordo com a literatura, o envelhecimento é responsável por uma perda parcial ou completa da inervação dos músculos intestinais, levando estes a uma subseqüente hipertrofia compensatória (SOUZA et al., 1993). Os resultados desta investigação cientifica confirmam tal afirmação, dado o aumento em 18\% na espessura das camadas musculares circular e longitudinal do colo quando comparados os animais do grupo A (ratos adultos) com os animais do grupo B (ratos de meia idade sedentários).

Por outro lado e embora não significativo estatisticamente, um aumento (7\%) na camada muscular circular e longitudinal também foi verificado nos animais do grupo C (ratos de meia idade submetidos a atividade física) quando comparado com os animais do grupo A (ratos adultos). De acordo com Van Liere, Hess e Edwards (1954), é concebível pensar que os músculos viscerais, como ocorre com a musculatura estriada esquelética, estariam fortalecidos (hipertrofiados) pelo aumento de trabalho.

\subsection{CONSIDERAÇÕES FINAIS}

Os resultados do presente trabalho mostram que algumas alterações próprias do envelhecimento estão presentes no plexo mioentérico do colo de ratos, ainda que 
incipientes. É possível que com o passar do tempo, até idades mais avançadas, estas alterações já estejam presentes em sua totalidade. Por outro lado, a atividade física mostrou-se, pelo menos parcialmente, importante para minimizar aquelas alterações. Novos trabalhos utilizando outros parâmetros deverão evidenciar os efeitos da atividade física em animais mais velhos. 
CONCLUSÃO 


\section{CONCLUSÃO}

Após a análise dos resultados e de acordo com os métodos empregados, podese concluir que:

- Um programa diário de atividade física, com intensidade sub-maxima (60\%) e longa duração (seis meses) é tolerado por animais de laboratório (ratos) e capaz de promover uma significativa melhora na performance e um ganho de peso corporal magro.

- Nenhuma diferença é observada no arranjo do plexo mioentérico quando comparado ratos de seis meses com ratos de doze meses e com a instituição de um programa de atividade física.

- A porção ascendente do colo apresenta uma distribuição heterogênea do plexo mioentérico enquanto que a porção descendente do colo apresenta uma distribuição homogênea.

- Nenhuma alteração neuronal significativa é verificada na ultra-estrutura dos neurônios entéricos do colo quando comparados ratos de seis meses com ratos de doze meses de idade.

- Uma membrana basal bem contornada e um colágeno mais agrupado e melhor delineado é encontrado no plexo mioéntérico do colo de ratos de meia idade sedentários. 
- A população de neurônios NADH-diaforase reativos do colo de ratos diminuiu com o envelhecimento e aumentou com a instituição de um programa de atividade física.

- Nenhuma diferença significativa é verificada na população de neurônios NADHdiaforase reativos entre as porções ascendente e descendente do colo de ratos.

- A população de neurônios NADPH-diaforase reativos do colo de ratos diminui significativamente com o envelhecimento e com a instituição de um programa de atividade física.

- Nenhuma diferença significativa é verificada na população de neurônios NADPHdiaforase reativos entre as porções ascendente e descendente do colo de ratos.

- Um aumento nas camadas musculares (circular e longitudinal) do colo de ratos é verificado com o envelhecimento e com a instituição de um programa de atividade física. 
REFERÊNCIAS 


\section{REFERÊNCIAS}

AIMI, Y.; KIMURA, H.; KINOSHITA, T.; MINAMI, Y.; FUJIMURA, M.; VINCENT, S. R. Histochemical localization of nitric oxide synthase in rat enteric nervous system. Neuroscience, v. 53, p. 553-560, 1993.

ANURAS, S.; LEONING-BAUCKE, V. Gastrointestinal motility in the elderly. J. Am. Geriatr. Soc., v. 32, p. 386-390, 1984.

ARAÚJO, E. J. A.; SANT'ANA, D. M. G.; MOLINARI, S. L.; MIRANTA NETO, M. H. Regional differences in the number and type of myenteric neurons in the descending colon of rats. Arq. Neuropsiquiatr., v. 61, p. 220-225, 2003.

ARIDA, R. M.; SCORZA, F. A.; SANTOS, N. F.; PERES, C. A.; CAVALHEIRO, E.A. Effect of physical exercise on seizure occurrence in a model of temporal lobe epilepsy in rats. Epilepsy Research, v. 37, p. 45-52, 1999.

ARIDA, R. M.; SCORZA, F. A.; SILVA, A. V.; SCORZA, F. A.; CAVALHEIRO, E. A. Differential effects of the spontaneous versus forced exercise in rats on the staining of parvalbumin-positive neurons in the hippocampal formation. Neuroscience Letters, v. 364, p. 135-138, 2004.

BAR-SHAI, A.; MAAYAN, C.; VROMEN, A.; UDASSIN, R.; NISSAN, A.; FREUND, H. R.; HANANI, M. Decreased density of ganglia and neurons in the myenteric plexus of familial dysautonomia patients. Journal of the Neurological Sciences, v. 220, p. 8994, 2004.

BELAI, A.; BURNSTOCK, G. Distribution and colocalization of nitric oxide synthase and calretin in myenteric neurons of developing, aging, and Crohn's disease human small intestine. Digestive Diseases and Sciences, v. 44, p. 1579-1587, 1999.

BELAI, A.; COOPER, S.; BURNSTOCK, G. Effect of age on NADPH-diaforasecontaining myenteric neurones of rat ileum and proximal colon. Cell Tissue Research, v. 279, p. $379-383,1995$.

BELAI, A.; SCHMIDT, H. H. H. W.; HOYLE, C. H. V.; HASSALL, C. J. S.; SAFFREY, M. J.; MOSS, J.; FÖRSTMANN, U.; MURAD, F.; BURNSTOCK, G. Colocalization of nitric oxide synthase and NADPH-diaforase in the myenteric plexus of the rat gut. Neuroscience Letters, v. 143, p. 60-64, 1992.

BINGHAM, S. A.; CUMMINGS, J. H. Effect of exercise and physical fitness on large intestinal function. Gastroenterology, v. 97, p. 1389-1399, 1989. 
BOCKUS, H. L. Textbook of Gastroenterology, 4. ed. Philadelphia: WB Saunders, 1985, v. II p. 116.

BOECKXSTAENS, G. E.; PELCKMANS, P. A.; HERMAN, A. G.; VAN MAERCKE, Y. M. Involvement of nitric oxide in the inhibitory innervation of the human isolated colon. Gastroenterology, v. 104, p. 690-697, 1993.

BRAZEL, C. Y.; RAO, M. S. Aging and neuronal replacement. Ageing Research Reviews, v. 3, p. 465-483, 2004.

BREHMER, A.; SCHRODL, F.; NEUHUBER, W. Morphological classifications of enteric neurons - 100 years after Dogiel. Anatomy Embryology, v. 200, p. 125-135, 1999.

BROCKLEHURST, J. C. Colonic disease in the elderly. In: JAMES, O.F.W. Clinics in Gastroenterology. W.B. London: Saunders Company, 1985. p. 725-747.

BROGNA, A.; FERRARA, R.; BUCCERI, A. M.; LANTERI, E.; CATALANO, F. Influence of aging on gastrointestinal transit time. Invest. Radiol., v. 34, p. 357-359, 1999.

BUTT, W. G.; WANG, I. S.; KAUFMAN, S. T.; RYAN, J. P.; COHEN, S. Age-related changes in rat colon mechanics. Gastrointest. Mot., v. 5, p. 123-128,1993.

CAMMACK, J.; READ, N. W.; CANN, P. A.; GREENWOOD, B.; HOLGATE, A. M. Effect of prolonged exercise on the passage of a solid meal through the stomach and small intestine. Gut, v. 23, p. 957-961, 1982.

CANTWELL, J. D. Gastrointestinal disorders in runners. J. Am. Med. Assoc., v. 246, p. 1404-1405, 1981.

$\mathrm{CHO}, \mathrm{C} . \mathrm{H}$. Current roles of nitric oxide in gastrointestinal disorders. Journal of Physiology, v. 95, p. 253-256, 2001.

CHRISTENSEN, J. Colonic motility. In: SCHULTZ, S.G.; WOOD, J.D. RAUNER, B.B. Handbook of Physiology - The gastrointestinal System. Maryland: American Physiological Socity, 1989. p. 939-973.

CHRISTENSEN, J.; STILES, M. J.; RICK, G. A.; SUTHERLAND, J. Comparative anatomy of the myenteric plexus of the distal colon in eight mammals. Gastroenterology, v.86, p. 706-713, 1984.

CHURCHILL, J. D.; GALVEZ, R.; COLCOMBE,S.; SWAIN, R. A.; KRAMER, A. F.; GREENOUGH, W. T. Exercise, experience and aging brain. Neurobiology of Aging, v.23, p. 941-955, 2002. 
CLARKSTON, W. K.; PANTANO, M. M.; MORLY, J. E.; HOROWITZ, M.; LITTLEFIELD, J. M.; BURTON, F. R.: Evidence for anorexia of aging. Gastrointestinal transit and hunger in healthy elderly vs. young adults. Am. J. Physiol., v. 272, p. R243 - R248, 1996.

CORTESINI, C.; CIANCHI, F.; INFANTINO, A.; LISE, M. Nitric oxide synthase and VIP distribution in enteric nervous system in idiopathic chronic constipation. Digestive Diseases and Sciences, v. 40, p. 2450-2455, 1995.

COSTA, M.; FURNESS, J. B.; LLEWELLYN-SMITH, I. J. Histochemistry of enteric nervous system. In: JONSON, L.R.; CHRISTENSEN, J.; JACKSON, M.J.; JACOBSON, E.D.; WALSH, J.H. , Physiology of the gastrointestinal tract, New York: Raven Press, .1987. p. 1-39.

COWEN, T.; JOHNSON, R. J. R.; SOUBEYRE, V.; SANTER, R. M. Restricted diet rescues rat enteric motor neurons from age related cell death. Gut, v. 47, p. 653-660, 2000.

DAPOIGNY, M.; SARNA, S. K. Effects of physical exercise on colonic motor activity. Am. J. Physiol., v. 260, p. G646-G652, 1991.

DAWSON, D. J.; KHAN, A. N.; SHREEVE, D. R. Psoas muscle hypertrophy: mechanical causes for "joggers trots"? Br. Med. J., v. 291, p. 787-788, 1985.

DISHMAN, R. K.; ARMSTRONG, R. B.; DELP, M. D.; GRAHAM, R. E.; DUNN, A. L. Open-field behavior is not related to treadmill performance in exercising rats. Physiol. Behav., v. 43, p. 541-546, 1988.

DONALD, I. P.; SMITH, R. G.; CRUIKSHANK, J. G; ELTON, R. A.; STODDART, M. E. A study of constipation in the elderly living at home. Gerontology, v. 31, p. 112-118, 1985.

EAKER, E. Y.; SALLUSTIO, J. E. The distribution of novel intermediate filament proteins defines subpopulations of myenteric neurons in rat intestine. Gastroenterology, v. 107, p. 666-674, 1994.

EL-SALHY, M.; SANDSTRÖM, O.; HOLMLUND, F. Age-induced changes in the enteric nervous system in the mouse. Mechanisms of Ageing and Development, v. 107, p. 93-103, 1999.

FINCH; C. E. Neurons, glia, and plasticity in normal brain aging. Neurobiol Aging, v.24, p. S123-127, 2003. 
FORDTRAN, J. S; SALTIN, B. Gastric emptying and intestinal absorption during prolonged severe exercise. J. Appl. Physiol., v. 23, p. 331-335, 1967.

FURNESS, J. B. Types of neurons in the enteric nervous system. Autonomic Nervous System, v. 81, p. 87-96, 2000.

FURNESS, J. B.; BORNSTEIN, J. C.; MURPHY, R.; POMPOLO, S. Roles of peptides in transmission in the enteric nervous system. TINS, v. 15, p. 66-71, 1992.

FURNESS, J. B.; COSTA, N. The enteric nervous system. New York: Churchill Livengston, 1987. p. 87-96.

FURNESS, J. B.; LI, Z. S.; YOUNG, H. M.; FORSTERMANN, U. Nitric oxide synthase in the enteric nervous system of the guinea-pig: a quantitative description. Cell Tissue Research, v. 277, p. 139-149, 1994.

GABELLA, G. Autonomic nervous system. In: The rat nervous system. 2. ed. London: Academic Press, 1995. p. 81-103.

GABELLA, G. Detection of nerve cells by a histochemical technique. Experientia, v. 25, p. 218-219, 1969.

GABELLA, G. Fall in the number of myenteric neurons in aging guinea pigs. Gastroenterology, v. 96, p. 1487-1493, 1989.

GABELLA, G. Innervation of gastrointestinal tract. International Review of Cytology, v. 79 , p. 129-193, 1979.

GABELLA, G. On the plasticity of the form and structure of enteric ganglia. Journal of the Autonomic Nervous System, v. 30, p. S59-S66, 1990.

GABELLA, G. The number of neurons in the small intestine of mice, guinea-pigs and sheep. Neuroscience, v. 22, p. 737-752, 1987.

GALLIGAN, J. J.; FURNESS, J. B.; COSTA, M. Migration of the myoelectric complex after interruption of the myenteric plexus: intestinal transection and regeneration of enteric nerves in the guinea pig. Gastroenterology, v. 97, p. 1135-1146, 1989.

GALLIGAN, J. J.; LePARD, K. J.; SCHNEIDER, D. A.; ZHOU, X. Multiple mechanisms of fast excitatory synaptic transmission in the enteric nervous system. Autonomic Nervous System, v. 81. p. 97-103, 2000. 
GILBERT, C. Optimal physical performance in athletes: key roles of dopamine in a specific neurotransmitter/hormonal mechanism. Mechanisms of Aging and Development, v. 84, p. 83-102, 1995.

GOMES, O. A..; DE SOUZA, R. R.; LIBERTI, E. A. A preliminary investigation of the effects of ageing on the nerve cell number in the myenteric ganglia of the human colon. Gerontology, v. 43, p. 210-217, 1997.

GOODRICK, C. L. Effects of long-term voluntary wheel exercise on male and female Wistar rats. Longevity, body weight and metabolic rate. Gerontology, v. 26, p. 22-33, 1980.

GRIDER, J. R. Interplay of VIP and nitric oxide in regulation of descending relaxation phase of peristalse. Am. J. Physiol., v. 264, p. G334-G340, 1993.

GUYTON, A. C.; HALL, J. E. Princípios gerais da função gastrointestinal - motilidade, controle nervoso e circulação. In: Tratado de fisiologia médica. 10. ed. São Paulo: Guanabara Koogan, 2002. p. 668-676.

HALL. K. E. Aging and neural control of the GI tract II. Neural control of the aging gut: can an old dog learn new tricks? Am. J. Physiol. Gastrointest. Liver Physiol., v. 283, p. G827-G832, 2002.

HASLER, W. L.; KUROSAWA, S.; OWYANG, C. Regional cholinergic differences between distal and proximal colonic myenteric plexus. Am. J. Physiol Gastrointest. Liver Physiol., v. 21, p. G404-G410, 1990.

HOLLINS, J. B.; CASTELL, D.O. Esophageal function in elderly men. A new look at presbuyoesophagus. Ann. Intern. Med., v. 80, p. 371, 1974.

HOLLOSZY, J. O.; SMITH, E. K.; VINING, M.; ADAMS, S. A. Effects of voluntary exercise on longevity of rats. J.Appl. Physiol., v. 59, p. 826-831, 1985.

HOLST, M. C.; POWLEY, T. L. Cuprolinic Blue (quinolinic phthalocyanine) counterstaining of enteric neurons for peroxidase immunocytochemistry. Journal of Neuroscience Methods, v. 62, p. 121-127, 1995.

HOROWITZ, M.; MADDERN, G. J.; CHATTERTON, B. E.; COLLINS, P. J.; HARDING, P. E.; SHERMAN, D. J. C. Changes in gastric emptying with age. Clin. Sci., v. 67, p. 213-218, 1984.

IBGE (Fundação Instituto Brasileiro de Geografia e Estatística). Censo demográfico: Brasil, 2000. Rio de Janeiro: IBGE, 2000. 
JARVINEN, M. K.; WOLLMANN, W. J.; POWROZEK, T. A.; SCHULTZ, J. A.; POWLEY, T. L. Nitric oxide synthase-containing neurons in the myenteric plexus of the rat gastrointestinal tract: distribution and regional density. Anat. Embryol., v. 199, p. 99112, 1999.

JOHNSON, R. J. R.; SCHEMANN, M.; SANTER, R. M.; COWEN, T. The effects of age on the overall population and on sub-populations of myenteric neurons in the rat small intestine. J. Anat., v. 192, p. 479-488, 1998.

JUNQUEIRA, L. C.; CARNEIRO, J. O tubo digestivo. In: Guanabara Koogan: Rio de Janeiro. 1995, p. 241-267. Histologia básica.

KARAOSMANOGLU, T.; AYGUN, B.; WADE, P. R.; GERSHON, M. D. Regional differences in the number of neurons in the myenteric plexus of the guinea pig small intestine and colon: an evolution of markers used to count neurons. The Anatomical Record, v. 244, p. 470-480, 1996.

KEEF, K. D.; DU, C.; WARD, S. M.; MCGREGOR, B.; SANDERS, K. M. Enteric inhibitory neural regulation of human colonic circular muscle: role of nitric oxide. Gastroenterology, v. 105, p. 1009-1016, 1993.

KHAN, T. A.; SHARAGGE, B. W.; CRISPIN, J. S.; LIND, J. F. Esophageal motility in the elderly. Dig. Dis. Sci., v. 20, p. 1049, 1977.

KONIGSMARK, B. W. Methods for the counting of neurons. In: NAUTA., W. J. H.; EBBESON, S. O. E. Contemporany Research Methods in Neuroanatomy. SpringerVerlag: New York. 1970, p. 315-340.

KRAMMER, H., J.; ZHANG, M.; KÜHNEL, W. Distribution of NADPH-diaphorasepositive neurons in the enteric nervous system of the human colon. Annals of Anatomy, v. 176, p. 137-141, 1994.

LI, M.; JOHNSON, C. P.; ADAMS, M. B.; SARNA, S. K. Cholinergic and nitrergic regulation of in vivo giant migration contractions in rat colon. Am. J. Gastrointest. Liver Physiol., v. 283, p. G544-G552, 2002.

LOMAX, A. E.; FURNESS, J. B. Neurochemical classification of enteric neurons in the guinea-pig distal colon. Cell Tissue Research, v. 302, p. 59-72, 2000.

MADSEN, J. L.: Effect of gender, age and body massaindex on gastrointestinal transit. Times Dig. Dis. Sci., v. 37, p. 1548-1553, 1992. 
MARTINEZ-CUESTA, M. A.; BARRACHINA, M. D.; BELTRAN, B.; CALATAYUD, S.; ESPLUGUES, J. Nitric oxide modulates the acute increase of gastrointestinal transit induced by endotoxin in rats: a possible role for tachykinins. J. Pharmacol., v. 49, p. 988-990, 1997.

MATTSON, M.P. Neuroprotective signaling and the aging brain: take away my food and let me run. Brain Research, v. 886, p. 47-53, 2000.

MC. DOUGLAS, J. N.; MILLER, M. S.; BURKS, T. F.; KREULEN, D. L.: Age-related changes in colonic function in rats. A.M.J. Physiol., v. 247, p. 6542-6546, 1984.

MCARDLE, W.D. Atividade física, saúde e envelhecimento. In: Fisiologia do exercício. 4ed. Rio de Janeiro: Guanabara Koogan: 1998. p. 605-633.

MESHKINPOUR, H.; SELOD, B. S.; MOVAHEDI, H.; NAMI, N.; JAMES, N.; WILSON, A. Effects of regular exercise in management of chronic idiopathic constipation. Digestive Diseases and Sciences, v. 43, p. 2379-2383, 1998.

MESSENGER, J.P.; BORNSTEIN, J.C.; FURNESS, J.B. Electrophysiological and morphological classification of myenteric neurons in the proximal colon of guinea-pig. Neuroscience, v. 60, p. 227-244, 1994.

MITOLO-CHIEPPA, D.; MANSI, G.; RINALDI, R.; MONTAGNANI, M.; POTENZA, M.A.; GENUALDO, M.; SERI, M.; MITOLO, C. I.; RINALDI, M. ALTOMARE, D. F.; MEMEO, V. Cholinergic stimulation and nonadrenergic, noncholinergic relaxion of human colonic circular muscle in idiopathic chronic constipation. Digestive Diseases and Sciences, v. 43, p. 2719-2726, 1998.

MIZUTA, Y.; TAKAHASHI, T.; OWYANG, C. Nitrergic regulation of colonic transit in rats. Am. J. Physiol., v. 277, p. G275-G279, 1999.

MONCADA, S.; PALMER, R. M. J.; HIGGS, E. A. Nitric oxide: physiology, pathophysiology and pharmacology. Pharmacol. Rev., v. 43, p. 109-142, 1991.

MOORE, J. G.; DATZ, F. L.; CHRISTIAN, P. E. Exercise increases solid meal gastric emptying rates in men. Digestive Diseases and Sciences, v. 35, p.428-432, 1990.

MOORE, J. G.; TWEEDY, C.; CHRISTIAN, P. E. Effect of age on gastric emptying of liquid-solid meals in man. Dig. Sci., v. 28, p. 340-340, 1983.

NEEPER, S. A.; GOMEZ-PINILLA, F.; CHOI, J.; COTMAN, C. W. Physical activity increases mRNA for brain-derived neurotrophic factor and nerve growth factor in rat brain. Brain Research, v. 726, p. 49-56, 1996. 
PHILLIPS, R. J.; KIEFFER, E. J.; POWLEY, T. L. Aging of the myenteric plexus:neuronal loss is specific to cholinergic neurons. Autonomic Neuroscience: Basic and Clinical, v. 106, p. 69-83, 2003.

PHILLIPS, R. J.; KIEFFER, E. J.; POWLEY, T. L. Loss of glia and neurons in the myenteric plexus of the aged Fischer 344 rat. Anat. Embryol., v. 209, p. 19-30, 2004.

PHILLIPS, R. J.; POWLEY, T. L: As the gut ages: Timetables for aging of innervation vary by organ in the Fischer 344 rat. The Journal of Comparative Neurology v. 434, p. 358-377, 2001.

PORTER, A. J.; WATTCHOW, D. A.; BROOKES, S. J. H.; COSTA, M. Cholinergic and nitrergic interneurones in the myenteric plexus of the human colon. Gut, v. 51, p. 70-75, 2002.

PORTER, A. J.; WATTCHOW, D. A.; BROOKES, S. J. H.; COSTA, M. The neurochemical coding and projections of circular muscle motor neurons in the human colon. Gastroenterology, v. 113, p. 1916-1923, 1997.

RAO, S. S. C.; BEATY, J.; CHAMBERLAIN, M.; LAMBERT, P.; GISOLFI, C. Effects of acute graded exercise on human colonic motility. Am. J. Physiol., v. 276, p. G1221G1226, 1999.

RIDDOCH, C.; TRINICK, T. Prevalence of running-induced gastrointestinal (GI) disturbances in marathon runners. Br. J. Sports Med., v. 22, p. 71-74, 1998.

ROBERTSON, G.; MESHKINPOUR, H.; VANDENBERG, K.; JAMES, N.; COHEN, A.; WILSON, A. Effects of exercise on total and segmental colon transit. J. Clin. Gatroenterol., v. 16, p. 300-303, 1993.

RUTTEN, B. P. F.; KORR, H.; STEINBUSCH, H. W. M.; SCHMITZ, C. the agingbrain: less neurons could be better. Mechanisms of Ageing and Development, v. 124, p. 349-355, 2003.

SAFFREY, M. J. Ageing of the enteric nervous system. Mechanisms of Ageing and Development, v. 125, p. 899-906, 2004.

SANDERS, K. M.; WARD, S. M. Nitric oxide as a mediator of nonadrenergic noncholinergic neurotransmission. Am. J. Physiol., v. 262, p. G379-G392, 1992.

SANTER, R. M. Survival of the population of NADPH-diaphorase stained myenteric neurons in the small intestine of aged rats. Journal of the Autonomic Nervous System, v. 49, p. 115-121, 1994. 
SANTER, R. M.; BAKER, D. M. Enteric neuron numbers and size in Auerbach's plexus in the small and large intestine of adult and aged rats. Journal of Autonomic Nervous System, v. 25, p. 59-67, 1988.

SARNA, S. K. Physiology and pathophysiology of colonic motor activity. Part II. Digestive Diseases and Sciences, v. 36, p. 998-1018, 1991.

SCHEMANN, M.; NEUNLIST, M. The human enteric nervous system. Neurogastroenterol. Motil., v. 16, p. 55-59, 2004.

SCHERER-SINGLER, U.; VINCENT, S. R.; KIMURA, H.; McGEER, E. G. Demonstration of unique population of neurons with NADPH-diaphorase histochemistry. J. Neurosci. Method., v. 9, n. 3, p. 229-234, 1983.

SILVA, G. J. J.; BRUM, P. C.; NEGRÃO, C. E.; KRIEGER, E. M. Acute and chronic effects of exercise on baroreflexes in spontaneously hypertensives. Hypertension, $v$. 30, n. 3, p. 714-719, 1997.

SIOU, G. P. S.; BELAI, A.; BURNSTOCK, G. A developmental study of the localization of NADPH-diaphorase in the ganglionated plexus of the guinea-pig gallbladder. Cell Tissue Research, v. 276, p. 61-68, 1994.

SKALICKY, M.; LITTITZ, H. B.; VIIDICK, A. Influence of physical exercises on aging rats: I: Life-long exercise preserves patterns of spontaneous activity. Mechanisms of Aging and Development, v. 87, p. 127-139, 1996.

SMITS, G. J. M.; LEFEBVRE, R. A.; Influence of age on cholinergic and inhibitory nonadrenergic noncholinergic responses in the rat ileum. European Journal of Pharmacology, v. 303, p. 79-86, 1996a.

SMITS, G.J.M.; LEFEBVRE, R.A.: Influence of aging on gastric emptying of liquids, small intestine transit and fecal out putin rats. Exp. Gerontol., v. 31, p. 589-596, 1996b.

SOERGEL, K.H.; ZBORALSKE, F.F; AMBERG, J.R. Presbyesophagus: esophageal motility in nonagenarians. J. Clin. Invest., v. 43, p. 1472, 1964.

SOUZA, R.R.; MORATELLI, H.B. BORGES, N.; LIBERTI, E.A. Age-induced nerve cell loss in the myenteric plexus of the small intestine in man. Gerontology, v. 39, p. 183188, 1993.

SZWEDA, P. A.; CAMOUSE, M.; LUNDBERG, K. C.; OBERLEY, T. D.; SZWEDA, L. I. Aging, lipofuscin formation, and free radical-mediated inhibition of cellular proteolytic systems. Ageing Research Reviews, v. 2, p. 383-405, 2003. 
TAKAHASHI, T.; OWYANG, C. Regional differences in the nitregic innervation between the proximal and the distal colon in rats. Gastroenterology, v. 115, p.1504-1512, 1998.

TAKAHASHI, T.; QOUBAITARY, A.; OWYANG, C.; WILEY, J.W. Decreased expression of nitric oxide synthase in the colonic myenteric plexus of aged rats. Brain Research, $\mathrm{V}$. 883, p. 15-21, 2000.

VAN GINNEKEN, C. V.; DE SMET, M.J.; VAN MEIR, F.J.; WEYNS, A.A. Microwave staining of enteric neurons using cuprolinic blue (quinolinic phthalocyanin) combined with enzyme histochemistry and peroxidase immunohistochemistry. The Journal of Histochemistry \& Cytochemistry, v. 47, p. 13-21, 1999.

VAN GINNEKEN, C. V.; VAN MEIR, F. J.; SYS, S.; WEYNS, A. Stereologic description of the changing expression of constitutive nitric oxide synthase and heme oxygenase in the enteric plexuses of the pig small intestine during development.The Journal of Comparative Neurology, v. 437, p. 118-128, 2001.

VAN LIERE, E.J.; HESS, H.H.; EDWARDS, J.E. Effect of physical training on the propulsive motility of the small intestine. J. Appl. Physiol., v. 88, n. 4, p. 186-187, 1954.

WADE, P. R.; COWEN, T. Neurodegeneration: a key factor in the ageing gut. Neurogastroenterol. Motil., v. 16, p. 19-23, 2004.

WADE, P. R.; EVANS, B.; LIEB, J. Age-related changes in submucosal neurons and motility in Fischer 344 rat distal colon. Gastroenterology, v.122, p. A20, 2002.

WILEY, J. W. Aging and neural control of the GI tract III. Senescent enteric nervous system: lessons from extraintestinal sites and nonmammalian species. Am. J. Physiol. Gastrointest Liver Physiol., v. 46, p. G1020-G1026, 2002.

YOUNG, H. M.; FURNESS, J. B.; SEWELL, P.; BURCHER, E. F.; KANDIAH, C. J. Total numbers of neurons in myenteric ganglia of the guinea-pig small intestine. Cell Tissue Research, v. 272, p. 197-200, 1993.

YOUNG, V. R.; RICE, H. A.; STEINHAUS, A. H. Studies in the physiology of exercise VII. The modifications of the colonic motility induced by exercise and some indications for a nervous mechanism. Am. J. Physiol., v. 99, p. 52-63, 1932. 